Research paper

\title{
A magnetostratigraphic calibration of Middle Miocene through Pliocene dinoflagellate cyst and acritarch events in the Iceland Sea (Ocean Drilling Program Hole 907A)
}

\author{
Michael Schreck ${ }^{\mathrm{a}, *}$, Jens Matthiessen ${ }^{\mathrm{a}}$, Martin J. Head ${ }^{\mathrm{b}}$ \\ a Alfred Wegener Institute for Polar and Marine Research, Am Alten Hafen 26, 27568, Bremerhaven, Germany \\ b Department of Earth Sciences, Brock University, 500 Glenridge Avenue, St. Catharines, Ontario, Canada L2S 3A1
}

\section{A R T I C L E I N F O}

\section{Article history:}

Received 3 January 2012

Received in revised form 26 July 2012

Accepted 4 August 2012

Available online 18 September 2012

\section{Keywords}

Miocene

Pliocene

dinoflagellate cyst

biostratigraphy

Iceland Sea

magnetostratigraphic calibration

\begin{abstract}
A B S T R A C T
A detailed dinoflagellate cyst investigation of the almost continuous Middle Miocene through Pliocene of Ocean Drilling Program Hole 907A in the Iceland Sea has been conducted at 100-kyr resolution. The investigated section is well constrained by magnetostratigraphy, providing for the first time an independent temporal control on a succession of northern high-latitude dinoflagellate cyst bioevents.

Based on the highest/lowest occurrences (HO/LO) and highest common occurrence (HCO) of 20 dinoflagellate cyst taxa and one acritarch species, 26 bioevents have been defined and compared with those recorded at selected DSDP, ODP, and IODP sites from the North Atlantic and contiguous seas, and in outcrops and boreholes from the onshore and offshore eastern U.S.A., and the North Sea and Mediterranean basins.

Comparisons reveal near-synchronous HOs of the dinoflagellate cysts Batiacasphaera micropapillata (3.8-3.4 Ma, mid-Pliocene) and Reticulatosphaera actinocoronata (4.8-4.2 Ma, Lower Pliocene) across the Nordic Seas and North Atlantic, highlighting their value on a supraregional scale. This probably applies also to Hystrichosphaeropsis obscura (upper Tortonian), when excluding ODP Hole 907A where its sporadic upper stratigraphic range presumably relates to cooling in the early Tortonian. Over a broader time span within the upper Tortonian, the $\mathrm{HO}$ of Operculodinium piaseckii likely also permits correlation across the Nordic Seas and North Atlantic, and the HO of Labyrinthodinium truncatum appears useful in the Labrador and Nordic Seas. Biostratigraphic markers useful for regional rather than supraregional correlation are the HOs of Batiacasphaera hirsuta (c. 8.4 Ma, upper Tortonian) and Unipontidinium aquaeductus (c. 13.6-13.9 Ma, upper Langhian), the HCO of the acritarch Decahedrella martinheadii (c. 6.7-6.3 Ma, Messinian), and possibly the LO of Cerebrocysta irregulare sp. nov. (c. $13.8 \mathrm{Ma}$, uppermost Langhian) across the Nordic Seas. Since Habibacysta tectata, B. micropapillata, R. actinocoronata and D. martinheadii have been observed in the Arctic Ocean, they are potentially useful for high latitude correlations in the polar domain.

The LOs of Habibacysta tectata and Unipontidinium aquaeductus suggest a mid- to late Langhian age (15.1-13.7 Ma) for deposits at the base of Hole 907A, thus providing new constraints on the age of basalts at the base of ODP Hole 907A.

The stratigraphically important dinoflagellate cysts Cerebrocysta irregulare sp. nov., and Impagidinium elongatum sp. nov. are formally described.
\end{abstract}

(C) 2012 Elsevier B.V. All rights reserved.

\section{Introduction}

Following the first published Neogene dinoflagellate cyst (dinocyst) biozonation by Williams (1975) on drill holes from offshore eastern Canada, assemblages of Miocene through Pliocene age have been reported frequently from the Northern Hemisphere, and our knowledge of their (paleo)ecology and stratigraphy has improved significantly (e.g. Williams and Bujak, 1985; Stover et al., 1996). It

\footnotetext{
* Corresponding author. Tel.: +494714831 1232.

E-mail address: Michael.Schreck@awi.de (M. Schreck).
}

soon became evident that dinocysts are the only microfossil group with a continuous Neogene record in the high northern latitudes, and their relatively high diversity predisposes them to detailed and reliable biostratigraphic correlations in a region critical for understanding the development of Northern Hemisphere climate (De Schepper and Head, 2008). Despite their biostratigraphic potential, and although Miocene and Pliocene sequences have been drilled successfully in the subpolar/polar North Atlantic and Arctic Ocean (Deep Sea Drilling Project [DSDP] Leg 38, Ocean Drilling Program [ODP] Legs 104, 105, 151, 162, and Integrated Ocean Drilling Program [IODP] Expedition 302), a consistent dinocyst biozonation for the Neogene is still not available. 
The independent age calibration of dinocyst events is hampered partly by an incomplete chronostratigraphic framework of DSDP/ODP sites, as few holes have robust age control. First-order absolute age determinations using magnetic polarity reversals are often fragmentary due to incomplete core recovery and drilling disturbances caused by the technical difficulties of drilling at high latitudes. Where available, magnetostratigraphy is primarily supported by calcareous microfossil datums, but the paucity of biogenic carbonate in the high northern latitudes restricts their use and has relegated stable oxygen and carbon isotope stratigraphy to a subordinate role (Fronval and Jansen, 1996; Matthiessen et al., 2009a). In addition, the low evolutionary turnover of these calcareous microfossil groups at high latitudes reduces the number of bioevents, which themselves are not necessarily synchronous between high and low latitudes (Backman et al., 1984). These deficiencies are compounded by the susceptibility of foraminiferal tests and calcareous placoliths to dissolution in the colder waters of high northern latitude sites (e.g. Spiegler and Jansen, 1989).

Dinocysts are therefore crucial for high-latitude biostratigraphy, but to further enhance their utility it is necessary to study those sites with robust chronostratigraphy as a means of independently calibrating the dinocyst datums (De Schepper and Head, 2008). ODP Hole 907A in the Iceland Sea (Fig. 1) is at one of few high northern latitude sites featuring a comparatively well-constrained magnetic polarity stratigraphy for the Middle and Upper Miocene (Channell et al., 1999a), in this case supported independently by silicoflagellate biostratigraphy (Amigo, 1999). Located today under the influence of cold water-masses exported from the Arctic Ocean, Hole 907A serves as a reference section for biostratigraphic correlation in the polar environments.
For these reasons the Middle Miocene to Pliocene interval of Hole 907A has been selected for a detailed palynostratigraphic study. We present a suite of biostratigraphically useful dinocyst and acritarch bioevents that are correlated for the first time in the Nordic Seas to the astronomically-tuned Neogene time scale (ATNTS 2004, Lourens et al., 2005), by using a revised magnetostratigraphy for Hole 907A (Channell et al., 1999a).

To identify those bioevents in Hole 907A that potentially extend biostratigraphic correlation into the high northern latitudes, we have compared the timing of our events with the published records of lower-latitude sites having independent age control. The most important of these sites are in the North Atlantic region, but we also compare our data with records from the North Sea and Mediterranean Sea basins and the on- and offshore eastern U.S.A. to evaluate possible ecologically- or climatically-induced asynchronies.

\section{Materials and methods}

ODP Leg 151 Hole 907A was drilled in the southwestern part of the Norwegian-Greenland Sea, on the eastern Iceland Plateau $\left(69^{\circ} 14.989^{\prime}\right.$ $\mathrm{N}, 12^{\circ} 41.894^{\prime} \mathrm{W} ; 2035.7 \mathrm{~m}$ water depth; Fig. 1), which is a flattopped platform defined by the $1800-\mathrm{m}$ contour. The drill hole penetrated a horizontal, undisturbed, pelagic sequence and reached a total depth of 224.1 meters below sea floor (mbsf). The lithology consists of $216.3 \mathrm{~m}$ of sediment (recovery $102.6 \%$ ) underlain by $8.7 \mathrm{~m}$ of basalts (recovery $60.2 \%$ ) at the base of the hole. The sediments mainly comprise unlithified silty clays and clayey silts, dark grayish brown in the upper half of the hole (0-56.3 mbsf) and olive gray, greenish gray, and grayish green in the lower half (56.3-216.3 mbsf; Shipboard Scientific Party,

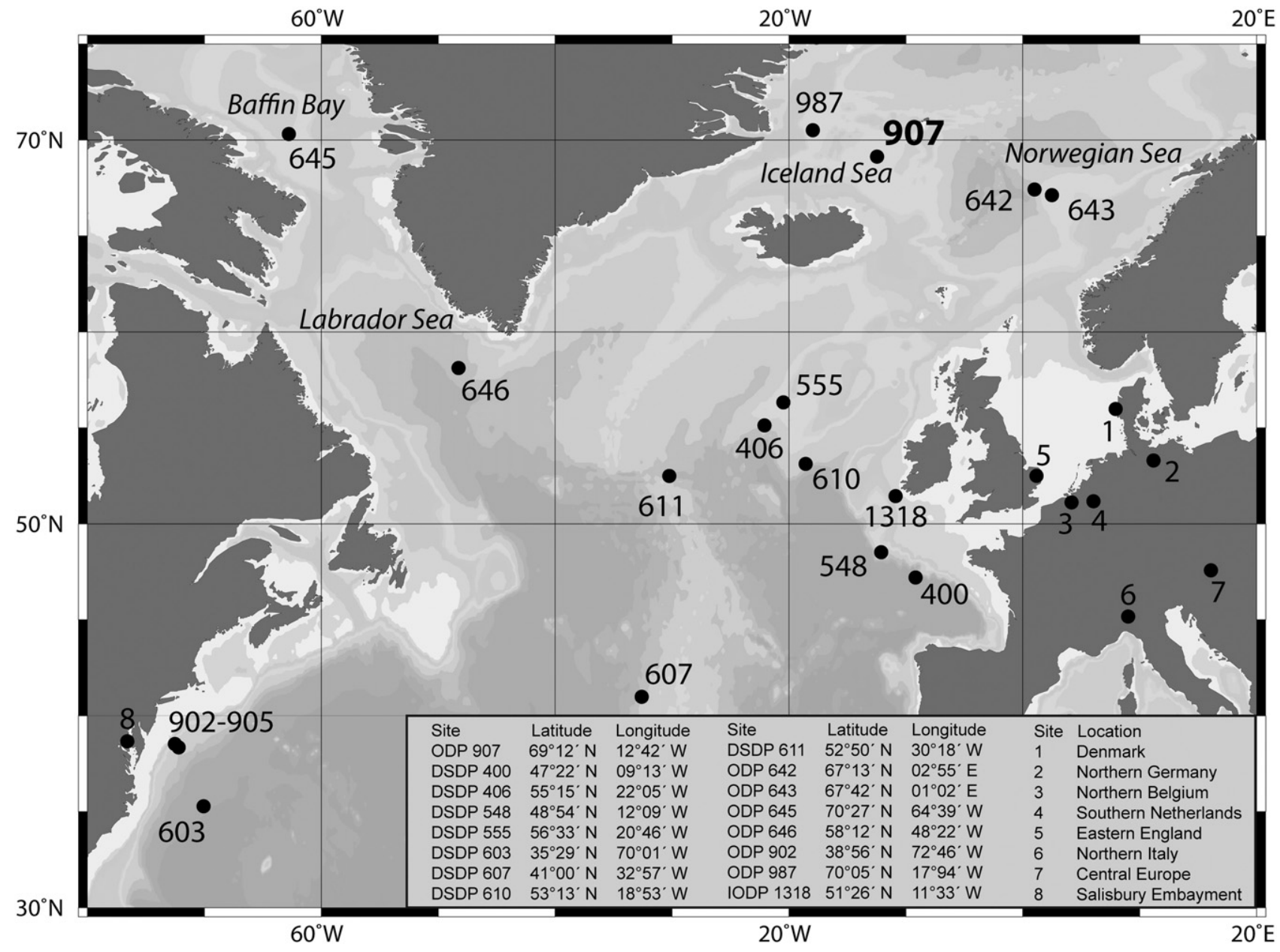

Fig. 1. North Atlantic and adjacent basins, showing the location of ODP Site 907 in the Iceland Sea and other sites discussed in the text. 


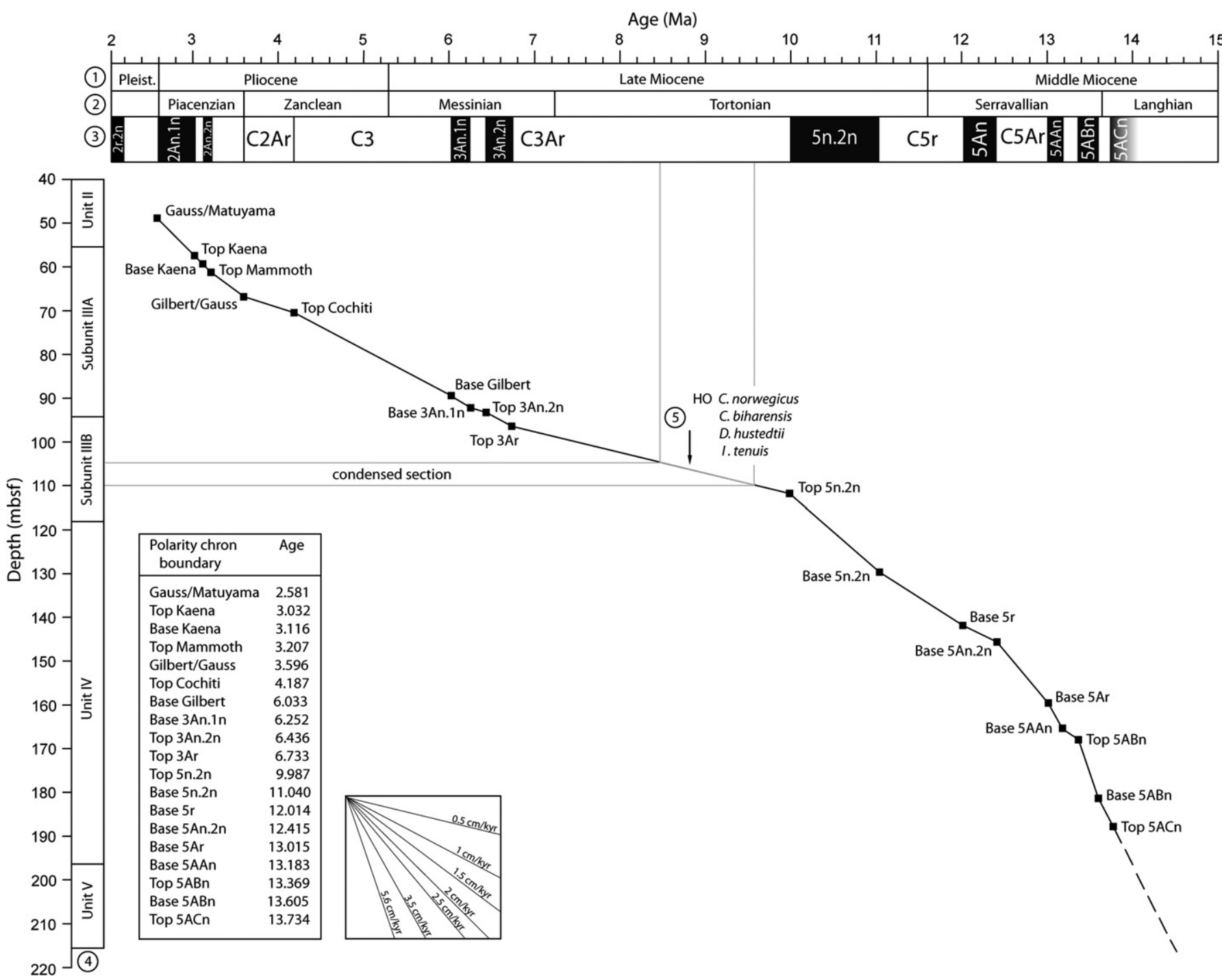

Fig. 2. Age/depth plot for ODP Hole 907A. Solid black line: Age model of Channell et al. (1999a) for ODP Hole 907A. Solid gray line: indicating possible unconformity/condensed section. Dashed black line: indicating our extrapolation of average sedimentation rates down-core (see Section 2.2). Symbols: (1) epoch/subepoch, (2) age, (3) magnetic polarity zones of Hole 907A after Channell et al. (1999a), (4) lithological units and subunits identified (Shipboard Scientific Party, 1995), and (5) stratigraphic position of diatom events (Koç and Scherer, 1996) used for interpretation of unconformity/condensed section.

1995). Five lithologic units (Fig. 2) were distinguished primarily by their siliciclastic, biogenic calcareous, and biogenic siliceous contents. Unit III is further subdivided into Subunit IIIA which is nannofossil ooze bearing, and Subunit IIIB that lacks calcareous nannofossils and has higher biogenic silica content (Fig. 2). All units have pervasive bioturbation.

Previous studies of Hole 907A include an initial dinocyst stratigraphy for the Middle Miocene through middle Lower Pliocene by Poulsen et al. (1996). Examining 49 samples, these authors recognized three provisional biozones (Mio3, Mio4-5, and questionably Mio6) but did not calibrate their informal biozones to the shipboard magnetostratigraphy (Shipboard Scientific Party, 1995).

\subsection{Sampling and palynological methods}

One hundred and twenty samples from Hole 907A (Fig. 3) were examined palynologically. Sample spacing varied with changes in the sedimentation rate and preservation of the core material. Based on the revised magnetostratigraphy of Channell et al. (1999a), the sampling resolution was set at c. $100 \mathrm{kyr}$. The investigated interval (Sample 907A-6H-3, 82-84 cm to Sample 907A-23H-CC, 10-12 cm) extends from Subchrons C2An to C5ACn, spanning the entire Pliocene and extending back to the early Middle Miocene.

Since $2 \mathrm{~cm}^{3}$ of sediment yielded only a small quantity of residue during post-cruise palynological studies (Poulsen et al., 1996), the sample volume used for this study was increased to $15 \mathrm{~cm}^{3}$. Samples were freeze-dried, weighed, and processed using standard palynological techniques, including treatment with cold $\mathrm{HCl}(10 \%)$ and cold $\mathrm{HF}$ (38-40\%), but without oxidation or alkali treatments. After each acid treatment the residue was neutralized with demineralized $\mathrm{H}_{2} \mathrm{O}$ and sieved over a $6 \mu \mathrm{m}$ polyester mesh to ensure that small palynomorphs $(<15 \mu \mathrm{m})$ would be retained. Two Lycopodium clavatum tablets (Batch no. $124961, X=12542, s= \pm 416$ per tablet) were added to each sample during $\mathrm{HCl}$ treatment to calculate palynomorph concentrations (Stockmarr, 1977). The residue was mounted on microscope slides with glycerine jelly and the coverslips were sealed with non-caking paraffin wax. All slides are stored at the Alfred Wegener Institute for Polar and Marine Research, Bremerhaven, Germany, with the exception of six slides containing all illustrated specimens of Cerebrocysta irregulare sp. nov. and Impagidinium elongatum sp. nov. These slides are housed in the Invertebrate Section of the Department of Palaeobiology, Royal Ontario Museum, Toronto, Ontario, Canada, under the catalog numbers ROM 61825-61830. 


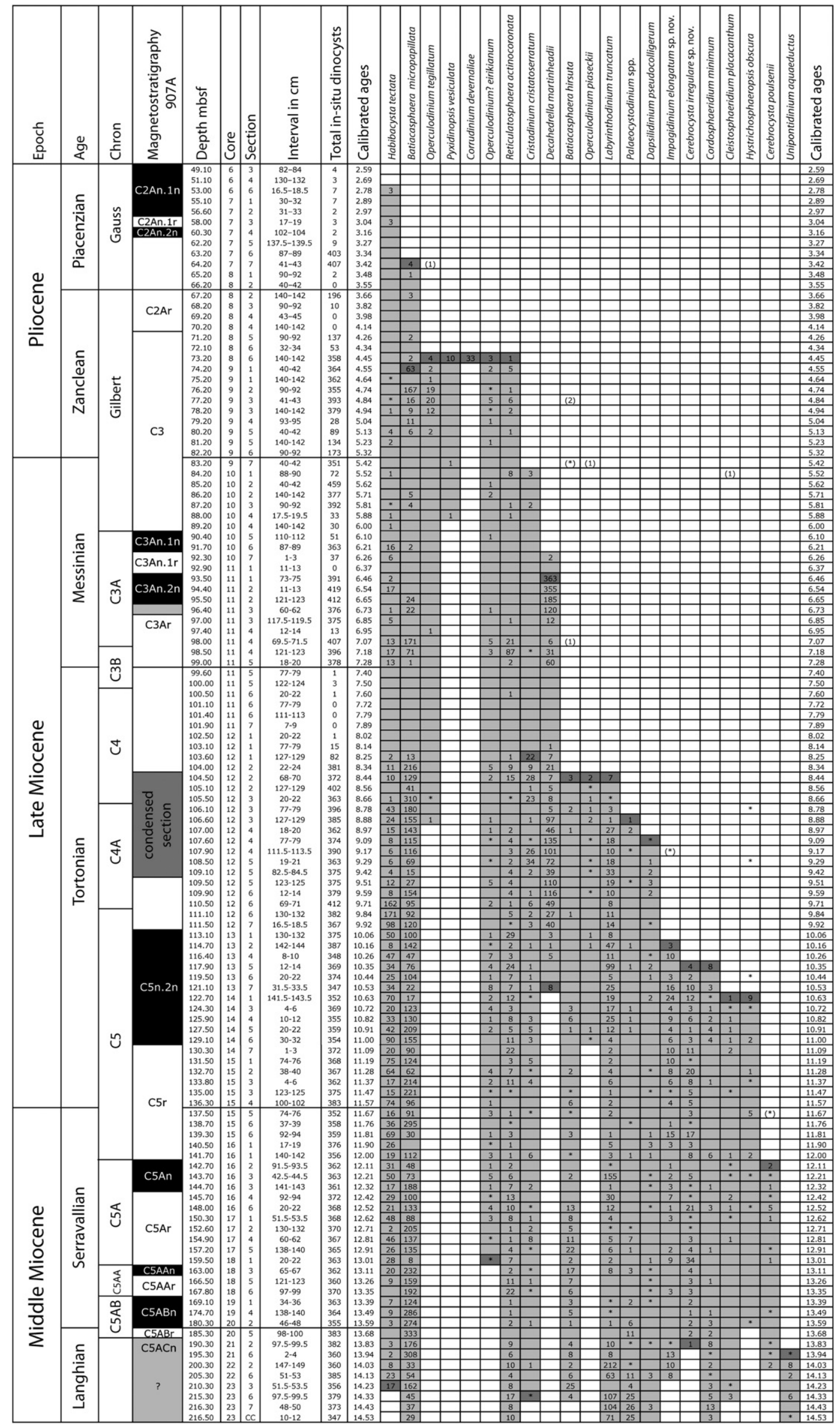


Wherever possible, a minimum of 350 (average $[\varnothing]=272$ ) dinocysts including the acritarch Decahedrella martinheadii were enumerated, and the dinocysts were identified where possible to species level. At least one slide was completely scanned for rare taxa not seen during regular counts. All counts and scans were performed with a Zeiss Axioplan 2 microscope at $63 \times$ and $20 \times$ objective lens, respectively. Transmitted light photomicrographs (Plates I-IV) were taken on a Leica DMR microscope with a Leica DFC490 digital camera. Here we present data only for the species discussed (Fig. 3), as the full data set will be published elsewhere.

Taxonomic nomenclature follows Fensome and Williams (2004) for the dinocysts and Manum (1997) for the acritarch. The full names of taxa are listed in Table 1.

\subsection{Age model}

The initial shipboard magnetic polarity stratigraphy of Hole 907A was based entirely on inclination data supported by biostratigraphy (Shipboard Scientific Party, 1995). Calcareous microfossils are rare to absent in the Miocene and Pliocene, and where they do occur, species diversity is low. In contrast, an initial radiolarian and diatom biostratigraphy was constructed for the Miocene and Pliocene (Shipboard Scientific Party, 1995), and a revised diatom biostratigraphy tied to an updated interpretation of the shipboard magnetostratigraphy was published by Koç and Scherer (1996), although these authors did not elaborate on the magnetostratigraphy in detail.

Only Hole 907A was drilled at Site 907 during ODP Leg 151 in 1993, but this site was reoccupied in 1995 during ODP Leg 162 when Holes 907B and C were drilled. Channell et al. (1999a) used all three holes to establish a composite section for Site 907 and proposed a new magnetostratigraphy for Hole 907A (Fig. 2). The age model for Site 907 is based primarily on the interpretation of the paleomagnetic record obtained during Legs 151 and 162, as well as measurements of discrete samples on Hole 907B during post-cruise studies (Channell et al., 1999a). Two silicoflagellate datums identified at 193.79 and 152.4 mbsf in Hole 907B (Amigo, 1999) were now used to constrain the magnetostratigraphy in the Miocene interval. These datums were calibrated at Hole 982B (ODP Leg 162, Rockall Plateau) to a calcareous nannofossil stratigraphy (see Channell et al., 1999a for details). The revised interpretation of the magnetic polarity signal is comparable to that suggested by Koç and Scherer (1996).

For the upper $100 \mathrm{~m}$ at Site 907, the shipboard pass-through inclination data indicate clearly-defined polarity zones that yield an excellent match with the magnetic polarity timescale (Shipboard Scientific Party, 1995; Channell et al., 1999a). However, the magnetostratigraphic interpretation of Channell et al. (1999a) indicates a condensed section or hiatus between c. 105 and 110 mbsf, representing an interval between 8.4 and 9.6 Ma according to ATNTS 2004. This interpretation is based on a series of sawtooth-like steps in the gamma-ray attenuation porosity evaluation (GRAPE) between 103 and $112 \mathrm{mbsf}$, associated with anomalously low magnetic susceptibility values for the same depth interval. Furthermore, the juxtaposition of the highest occurrences of the diatom species Coscinodiscus norwegicus, Cymatosira biharensis, Ikebea tenuis, and Denticulopsis hustedtii between 107.2 and 109.0 mbsf (113-115 mbsf according to Channell et al., 1999a) implies a hiatus at this level (Koç and Scherer, 1996). As there is no sedimentological evidence for a hiatus, this interval probably instead represents a condensed section.

For the 110-185 mbsf interval, the correlation between the three holes of Site 907 is fairly straightforward (Channell et al., 1999a), although the Shipboard Scientific Party (1995) interpreted the absence of many of the C5An short normal subchrons below 129 mbsf as another discontinuity. However, this is not supported by biostratigraphic data.

Although the paleomagnetic signal is well defined between 140 and 195 mbsf, it is difficult to match with the polarity time scale. The Shipboard Scientific Party (1995) interpreted this interval as greatly expanded, and the four normal polarity zones were correlated to Subchrons C5AA to C5AD. However, Channell et al. (1999a) correlated the lowest polarity chron boundary at 187.85 mbsf to the top of Subchron C5ACn.

The maximum age of the sedimentary sequence is derived from ${ }^{40} \mathrm{Ar} /{ }^{39} \mathrm{Ar}$ dating of tholeiitic basalts recovered from the base of Hole 907A. The age of $13.2 \pm 0.3 \mathrm{Ma}$ represents the isochron of the low-temperature heating steps and is considered relatively accurate, but a low potassium content and low radiogenic yields place limits on precision (Davis and McIntosh, 1996). The authors regarded their results as tentative because the dating had not yet been duplicated. The radiometric age is slightly younger than the top of Subchron C5ACn (13.7 Ma), implying that either the age or the magnetostratigraphy are in error. Even a slightly older age for the basalts would imply much higher sedimentation rates for the lowest $c$. $28 \mathrm{~m}$ than the average of $3.5-5.7 \mathrm{~cm} / \mathrm{ka}$ for the lower part this hole. This is unlikely because no indications of mass transport have been found in that part of the hole (Shipboard Scientific Party, 1995). Therefore, we consider the paleomagnetic interpretation more reliable than a single ${ }^{40} \mathrm{Ar} /{ }^{39} \mathrm{Ar}$ date, and so have extrapolated sedimentation rates down-core. Sedimentation rates between the lowest three tie-points are fairly constant (Fig. 2), and we used these rates to calculate tentatively an age of $14.5 \mathrm{Ma}$ for our lowermost sample (907A-23H-CC, 10-12 cm; 216.5 mbsf) at the base of the sedimentary sequence. The ages of the polarity chron boundaries given by Channell et al. (1999a) have been updated to ATNTS 2004 (Lourens et al., 2005). This age model has been used to calculate sedimentation rates and numerical ages for each sample and bioevent by linear interpolation between tie-points.

\subsection{Definition of biostratigraphic events}

We follow the concept of biostratigraphic datums used by De Schepper and Head (2008). The abbreviations LO and HO indicate the lowest and highest in-situ stratigraphic occurrence of taxa, respectively. The HPO represents the highest persistent occurrence (i.e. in successive samples) of a taxon, even where such occurrences are marked by a few specimens only. Sporadic occurrences above an HPO might represent reworking (De Schepper and Head, 2008). A highest common occurrence (HCO) marks the highest sample in which a particular species is noticeably abundant, although it will occur above this level in much lower numbers.

\subsection{Uncertainties in the assessment of bioevent ages}

When calculating numerical ages for biostratigraphic events, those inaccuracies associated with the construction of the age model, sample spacing, and bioturbation must be considered (e.g. Weaver and Clement, 1987; De Schepper and Head, 2008). Furthermore, the temporal distribution and abundance variations of species may cause inaccurate definitions of bioevents.

Paleomagnetic boundaries are placed at the midpoint between two adjacent samples that record a reversal in inclination, thus

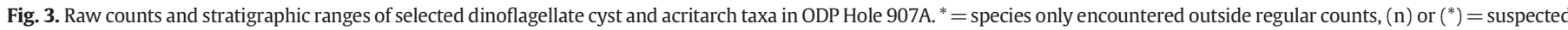

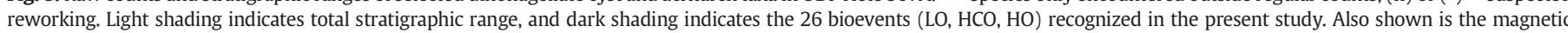
polarity stratigraphy of Hole 907A (Channell et al., 1999a). Total in-situ counts refers to the total in-situ dinocysts plus the acritarch Decahedrella martinheadii. 
introducing an error that can be as much as half the age difference between these samples (Weaver and Clement, 1987). For Hole 907A, the distance between two samples across a magnetic reversal varies from 10 to $20 \mathrm{~cm}$ (Ø $12 \mathrm{~cm}$ ). With an average sedimentation rate of $2 \mathrm{~cm} / \mathrm{kyr}$, this accounts for an error of 5-10 kyr (Ø $6 \mathrm{kyr}$ ) on the age of the magnetic boundary.

The same applies for the highest and lowest occurrence (HO and LO) of a species, which might be anywhere between the lowest/ highest sample containing a species and the next sample that does not contain that species. For Hole 907A sampled at 100-kyr resolution, this accounts for an average error of $\pm 50 \mathrm{kyr}$ in the assessment of the true $\mathrm{LO}$ or $\mathrm{HO}$ of a species.
As mentioned previously, bioturbation was recorded in all lithological units (Shipboard Scientific Party, 1995). In several North Atlantic cores, Ruddiman and Glover (1972) found bioturbation of volcanic ash up to $44 \mathrm{~cm}$ below and $27 \mathrm{~cm}$ above the peak abundance of an ash layer. Based on these estimates for bioturbation and an average sedimentation rate of $2 \mathrm{~cm} / \mathrm{kyr}$ for the studied interval in Hole 907A, the average errors for HOs and LOs due to bioturbation are $22 \mathrm{kyr}(\varnothing 11 \mathrm{kyr})$ and $13.5 \mathrm{kyr}(\varnothing 7 \mathrm{kyr})$, respectively.

Reworking of dinocysts is another potential source of error. This problem is not unique to dinocysts, but their durability makes them particularly susceptible. Aside from preservational differences and other evidence, the stratigraphic pattern of cyst occurrences can be

\section{Plate I. All photomicrographs are in bright field illumination. Various magnifications. Max. dia. = maximum diameter.}

$1-3$

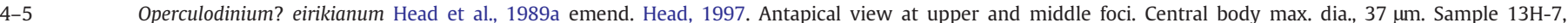
315-325 cm; slide 1; 048/1.

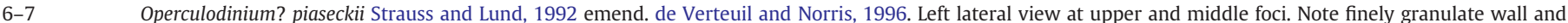
solid, distally-truncated processes with small vesicles at base of some processes. Central body length, $37 \mu \mathrm{m}$. Sample 12H-3, 77-79 cm; slide 1 ; N52/2.

8-10 Operculodinium tegillatum Head, 1997. Dorsal view at upper, middle and lower foci. Central body max. dia., $37 \mu \mathrm{m}$. Sample 8 H-6, $140-142 \mathrm{~cm}$; slide 1 ; L46/4.

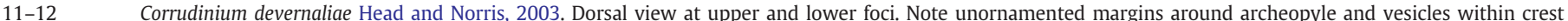
bases. Central body length, $32 \mu \mathrm{m}$. Sample 8H-6, 140-142 cm; slide 1; P39/0.

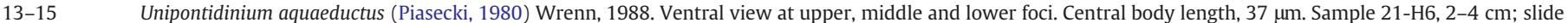
$1 ; 041 / 2$.

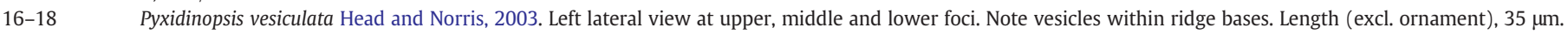
Sample 8H-6, 140-142 cm; slide 1; 038/4.

19-20 Habibacysta tectata Head et al., 1989a. Ventral view at middle and lower foci. Max dia., 38 m. Sample 12H-6, 130-132 cm; slide 1; Q42/3.

Plate II. All photomicrographs are in bright field illumination. Various magnifications. Max. dia. = maximum diameter. (see on page 8 )

1-5 Hystrichosphaeropsis obscura Habib, 1972

1-4 Dorsal view at upper through lower foci. Periblast length, $95 \mu \mathrm{m}$. Sample 15H-5, 74-76 cm; slide 1; 047/2.

5 Dorsal view at mid-focus. Note rounded opening (hydropyle) in antapical plate. Periblast length, 94 m. Sample 15H-5, 74-76 cm; slide 1; P48/0.

6-20 Impagidinium elongatum sp. nov.

6-10 Holotype in right latero-dorsal view at upper through lower foci. Central body length, 56 um. Sample 13H-6, 20-22 cm; slide 2; P52/2 (ROM 61826).

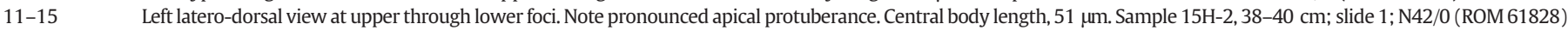

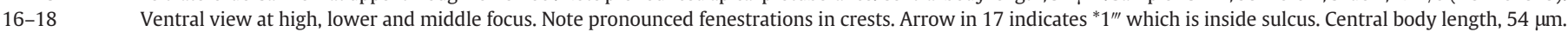
Sample 15H-1, 74-76 cm; slide 1; S37/2 (ROM 61827).

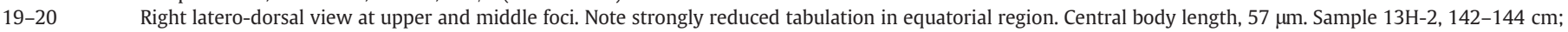
slide $1 ;$ J43/0 (ROM 61825).

Plate III. All photomicrographs are in bright field illumination. Various magnifications. Max. dia. = maximum diameter. (see on page 9 ) about $2.0 \mu \mathrm{m}$ long. Central body max. dia., $27 \mu \mathrm{m}$. Sample $17 \mathrm{H}-5,138-140 \mathrm{~cm}$; slide 1; J45/4.

4-10 Batiacasphaera micropapillata Stover, 1977.

4-5 Vermiculate-rugulate morphotype. Antapical view at middle and lower foci. Central body max. dia., $26 \mu \mathrm{m}$. Sample 21H-6, 2-4 cm; slide 1; P38/0.

6-7 Vermiculate-rugulate morphotype. Oblique antapical view at upper and middle foci. Central body max. dia., $30 \mu \mathrm{m}$. Sample $14 \mathrm{H}-4,10-12 \mathrm{~cm}$; slide 1 ; N43/2.

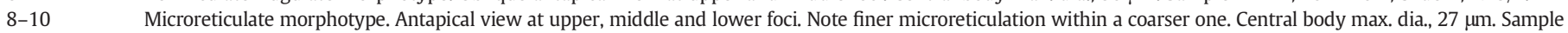
$15 \mathrm{H}-5,74-76 \mathrm{~cm}$; slide $1 ; \mathrm{M} 46 / 0$

11-20 Cerebrocysta irregulare sp. nov.

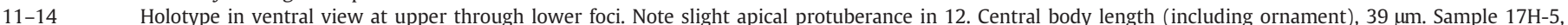
138-140 cm; slide 1; P43/4 (ROM 61830).

15-17 Left lateral view at upper, middle and lower foci. Central body max. dia. (including ornament), 42 $4 \mathrm{~m}$. Sample 16H-1, 17-19 cm; slide 1; 050/1 (ROM 61829).

18-20 Dorsal view at upper, middle and lower foci. Central body length (including ornament), 34 $\mu \mathrm{m}$. Sample 17H-5, 138-140 cm; P42/1 (ROM 61830).

Plate IV. All photomicrographs are in bright field illumination. Various magnifications. Max. dia. = maximum diameter. (see on page 10)

10-12

$13-15$

13-14

15

Cerebrocysta poulsenii de Verteuil and Norris, 1996. Dorsal view at upper and middle foci. Central body length, $32 \mu \mathrm{m}$. Sample 16H-3, 42.5-44.5 cm; M49/0. Labyrinthodinium truncatum Piasecki, 1980 emend. de Verteuil and Norris, 1996.

Apical view at middle and lower foci. Central body max. dia., $29 \mu \mathrm{m}$. Crest height, 6.5-8.5 $\mu \mathrm{m}$. Sample 16H-1, 17-19 cm; slide 1; 052/0.

Morphotype with crests showing marked distal expansion. Apical view with upper focus on operculum which is partly collapsed into cyst, and at middle focus. Central body max. dia., $25 \mu \mathrm{m}$. Crest height, 5.0-5.5 $\mu \mathrm{m}$. Sample 17H-4, 60-62 cm; slide 1; K49/3.

Reticulatosphaera actinocoronata Matsuoka, 1983 emend. Bujak and Matsuoka, 1986. View uncertain at upper and middle foci. Central body max. dia., $26 \mu$ m. Sample 13H-7, 315-325 cm; M38/1.

Dapsilidinium pseudocolligerum (Stover, 1977) Bujak et al., 1980. Antapical view at mid-focus. Central body surface is granulate, and two pairs of processes (not illustrated) are fused for most of their length. Central body max. dia., $35 \mu \mathrm{m}$. Sample 13H-6, $20-22 \mathrm{~cm}$; slide 1; E41/1.

Cristadinium cristatoserratum Head et al., 1989a. Ventral view at upper, middle and lower foci. Length, 45 mm. Sample 17H-4, 60-62 cm; slide 1; N39/4. Palaeocystodinium spp.

Specimen resembling Palaeocystodinium golzowense Alberti, 1961. Left lateral view at upper and lower foci. Horns and body unornamented. Total length, $155 \mu$ m; central body length, $63 \mu \mathrm{m}$. Sample 13H-2, 142-144 cm; slide 1; L42/4.

Palaeocystodinium sp. cf. P. miocaenicum Strauss in Strauss et al., 2001. Ventral view at upper focus. Surface smooth except for pronounced alignment of granulation on horns, and no indication of tabulation around the archeopyle. Total length, $120 \mu \mathrm{m}$; central body length, $47 \mu \mathrm{m}$. Sample 23H-6, 97.5-99.5 cm; R48/4. Grouped with Palaeocystodinium spp. in the range chart.

Cleistosphaeridium placacanthum (Deflandre and Cookson, 1955) Eaton et al., 2001. Antapical view at upper and middle foci. Note ridges demarcating process complexes. Central body max. dia., $73 \mu \mathrm{m}$. Sample 23H-6, 97.5-99.5 cm; slide 1; S49/0.

Decahedrella martinheadii Manum, 1997. Note thin internal sac in 18. Overall max. dia. $73 \mu \mathrm{m}$. Sample 11H-1, 73-75 cm; slide 1; M50/0. 

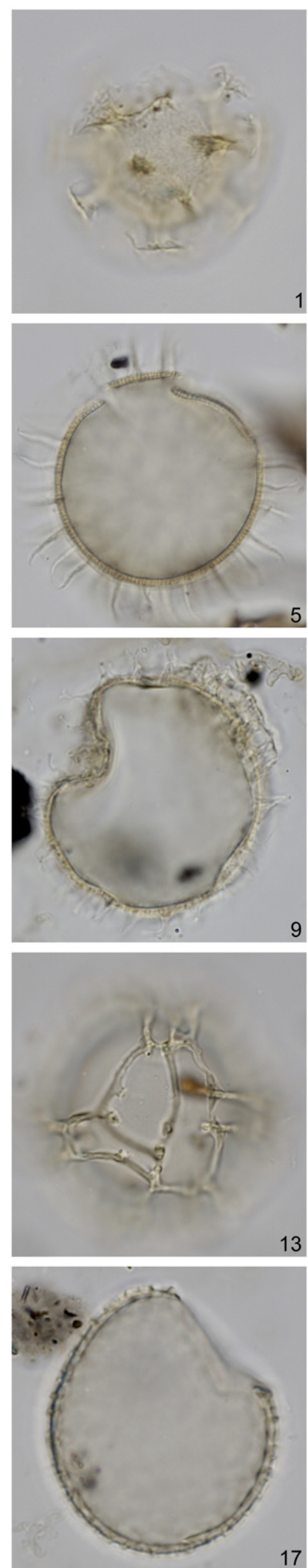

2

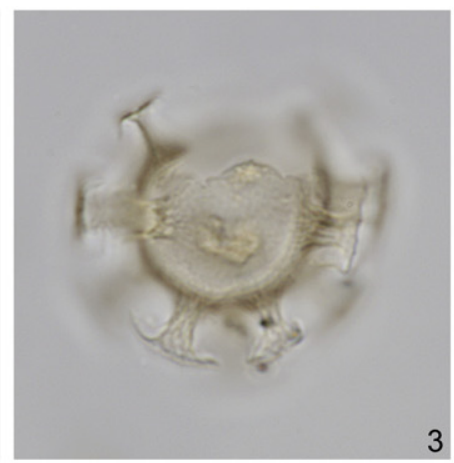

3
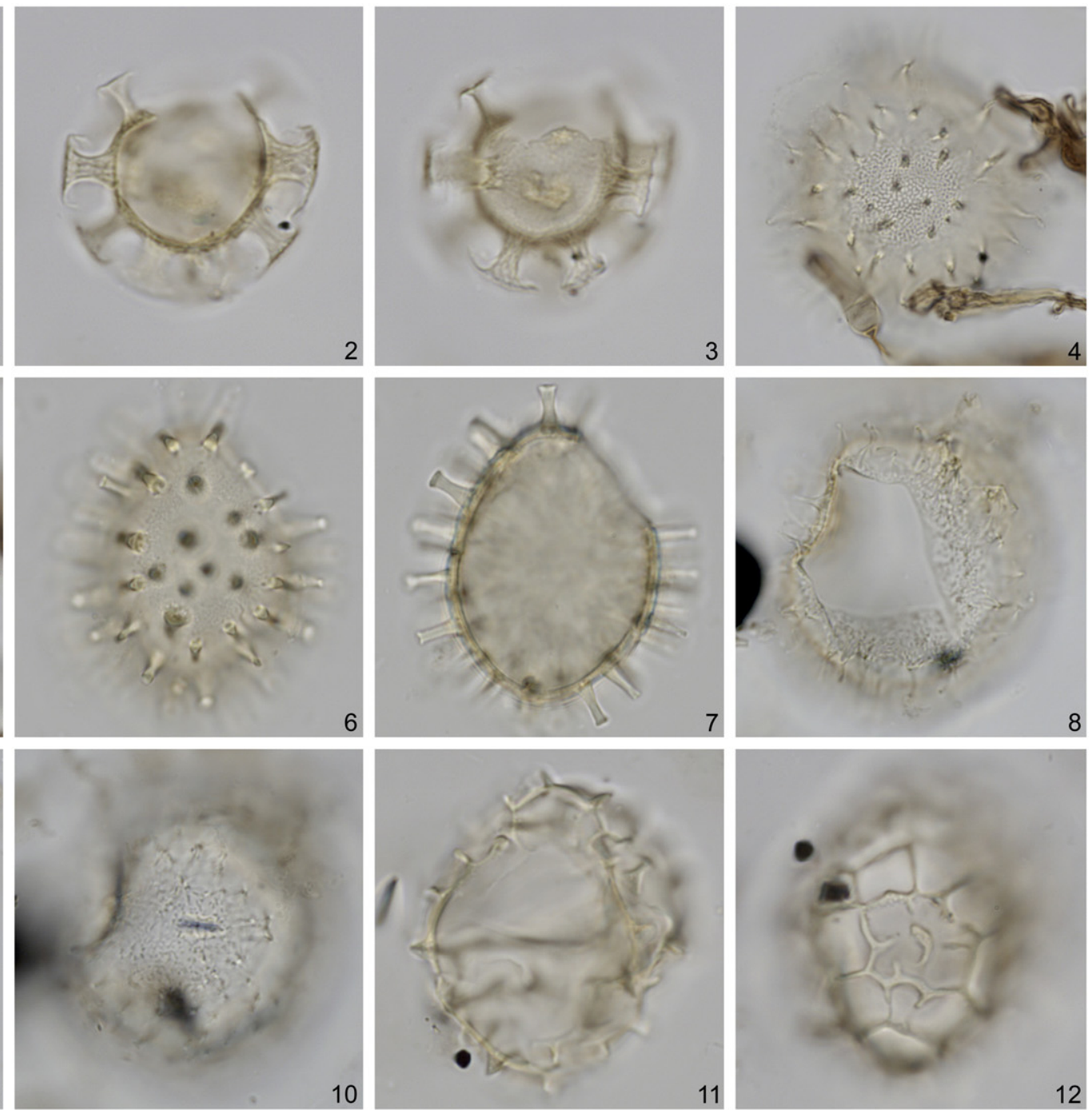

11

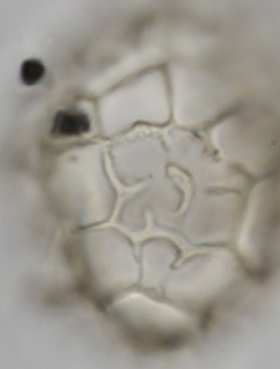

12
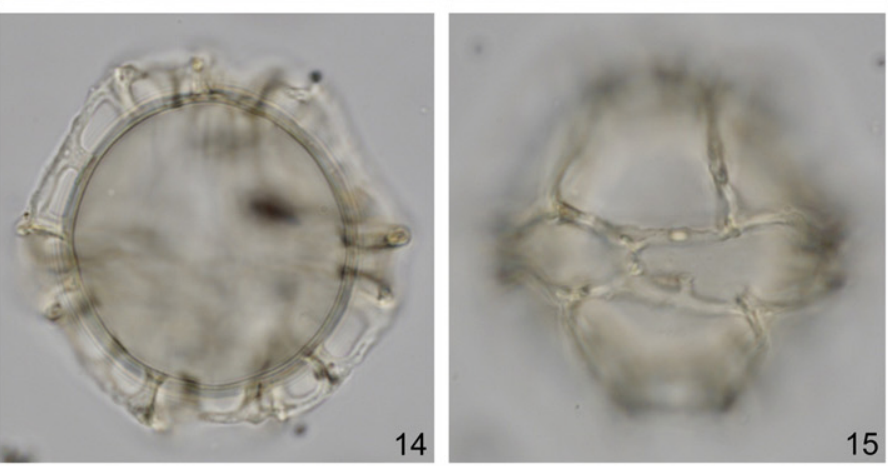

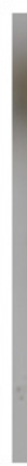
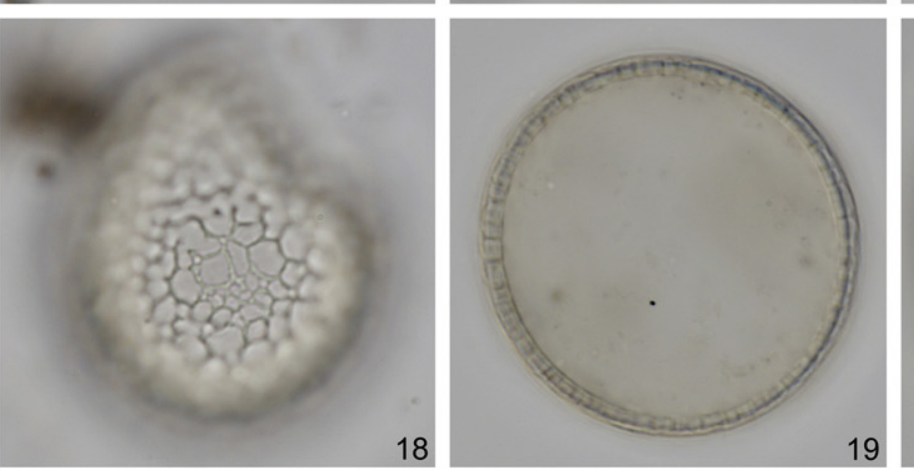

16
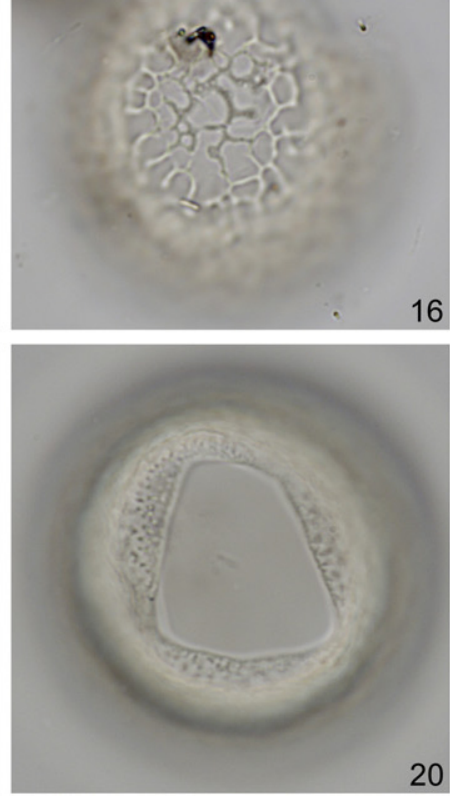

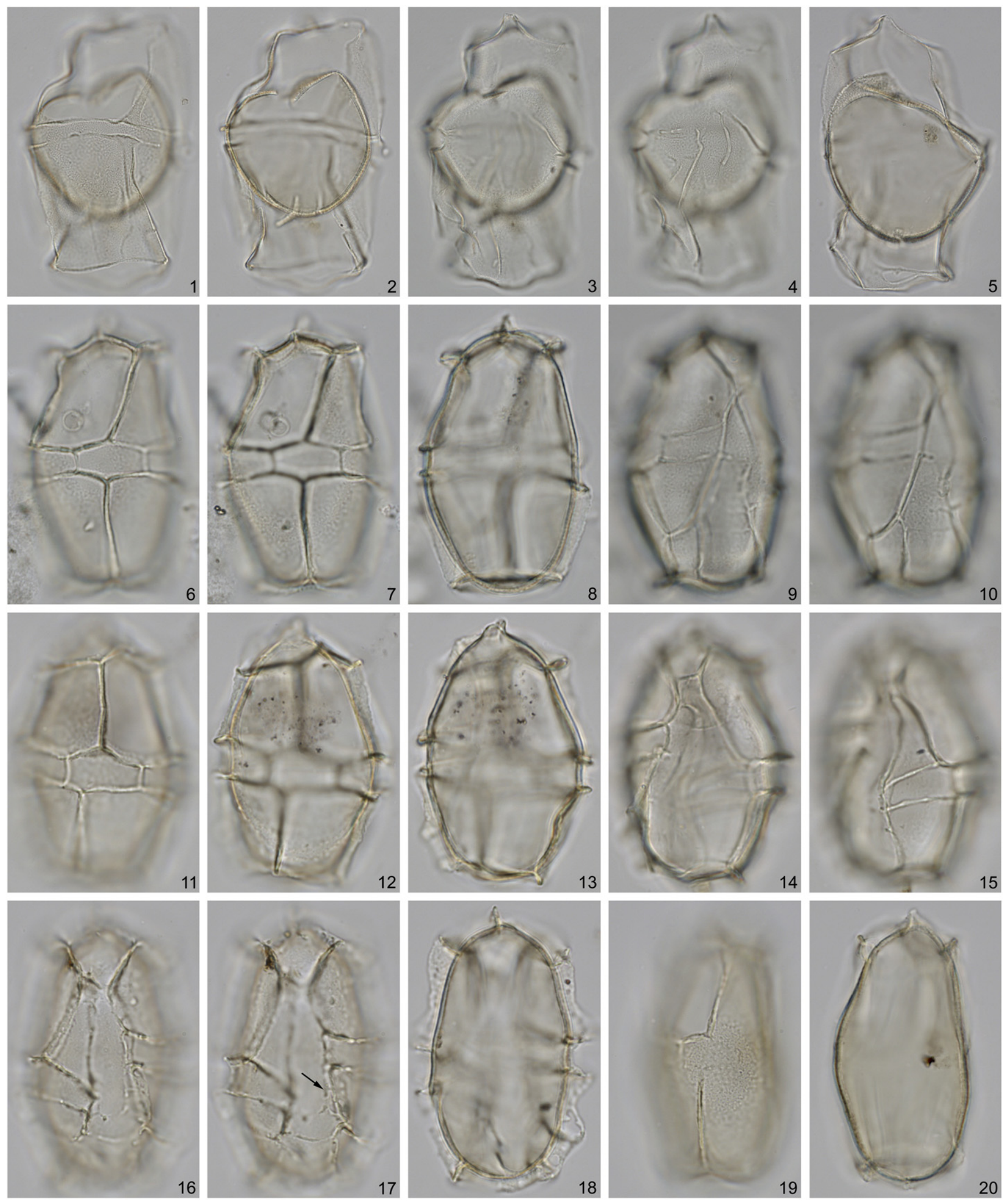

Plate II. (caption on page 6)

used to infer reworking. Species that are usually abundant through their stratigraphic range may occur in low numbers immediately above, invoking the possibility of reworking. Rare species might occur in low but persistent numbers to the top of their true stratigraphic range, with reworked specimens occurring only sporadically above it. The descriptive terms HCO and HPO can be useful in these two contexts. 

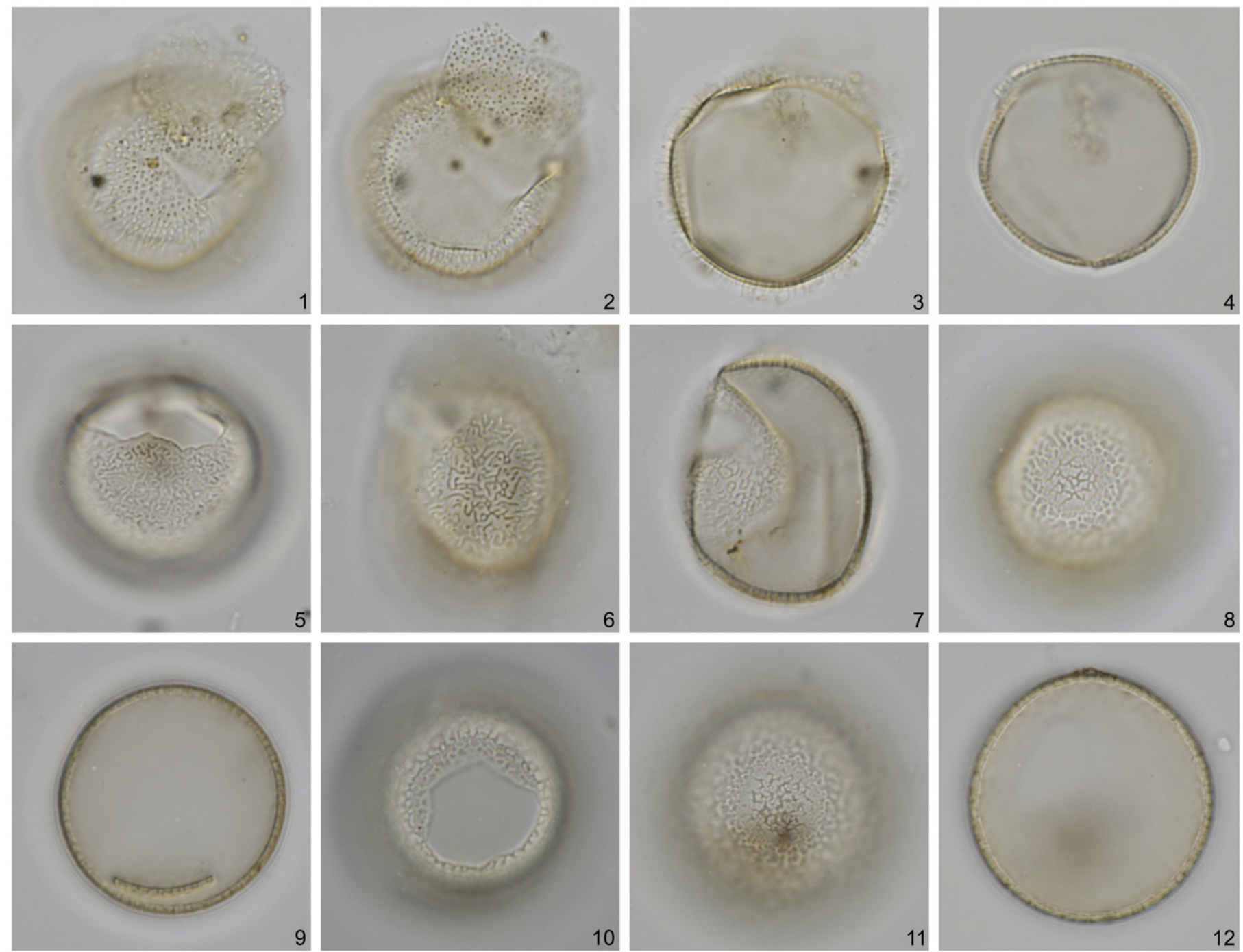

13
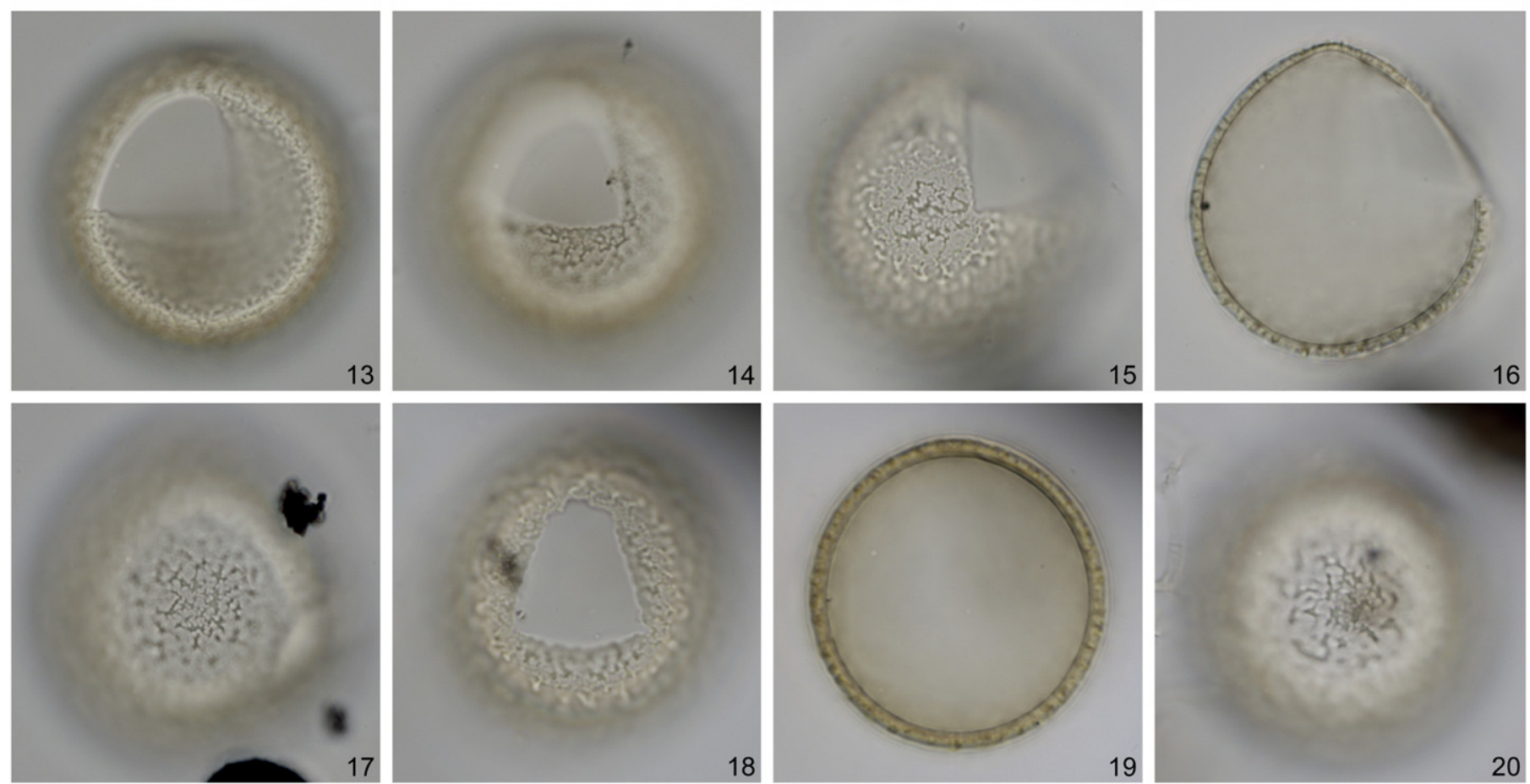

Plate III. (caption on page 6) 

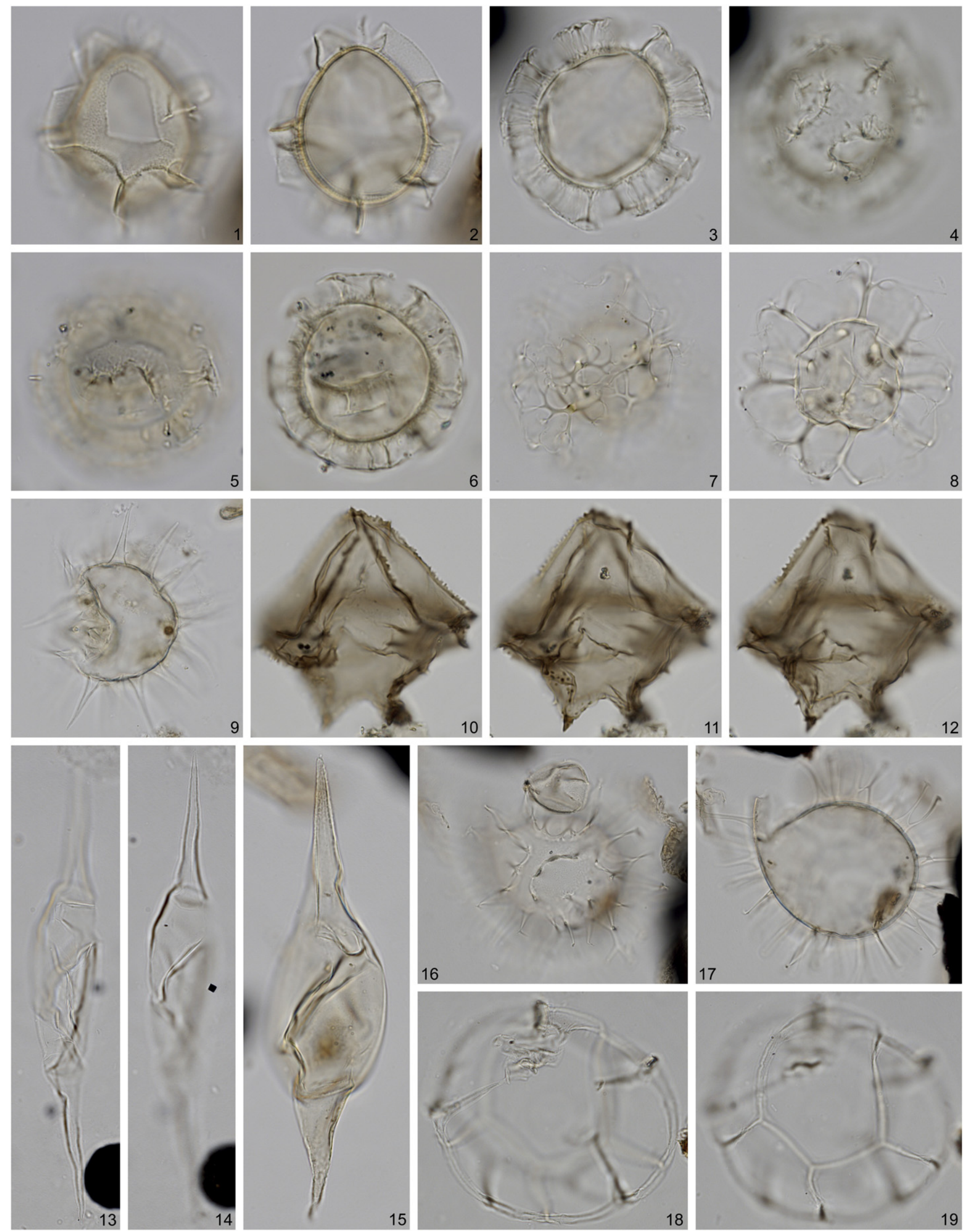

16
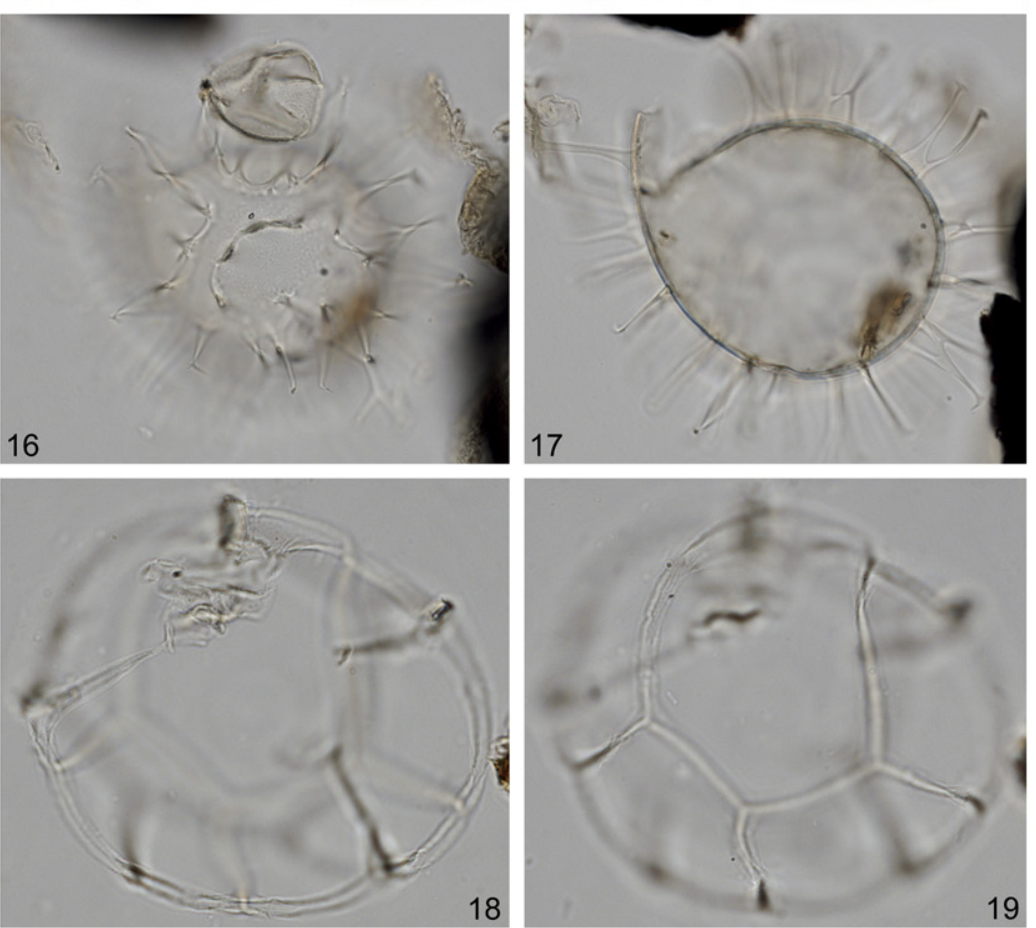

Plate IV. (caption on page 6) 
Table 1

Dinoflagellate cyst and acritarch species and their codes used in the present study of ODP Hole 907A.

\begin{tabular}{|c|c|c|}
\hline DINOFLAGELLATE CYSTS & Code & Plate \\
\hline Batiacasphaera hirsuta Stover, 1977 & Bhir & Plate III, 1-3 \\
\hline Batiacasphaera micropapillata Stover, 1977 & Bmic & Plate III, 4-10 \\
\hline Cerebrocysta irregulare sp. nov. & Cirr & Plate III, 11-20 \\
\hline Cerebrocysta poulsenii de Verteuil and Norris, 1996 & Cpou & Plate IV, $1-2$ \\
\hline $\begin{array}{l}\text { Cleistosphaeridium placacanthum (Deflandre and } \\
\text { Cookson, 1955) Eaton et al., } 2001\end{array}$ & Cpla & Plate IV, $16-17$ \\
\hline Corrudinium devernaliae Head and Norris, 2003 & Cdev & Plate I, 11-12 \\
\hline $\begin{array}{l}\text { Cordosphaeridium minimum sensu Benedek and } \\
\text { Sarjeant (1981) }\end{array}$ & Cmin & Plate I, 1-3 \\
\hline Cristadinium cristatoserratum Head et al., 1989a & Ccri & Plate IV, 10-12 \\
\hline $\begin{array}{l}\text { Dapsilidinium pseudocolligerum (Stover, 1977) } \\
\text { Bujak et al., } 1980\end{array}$ & Dpseu & Plate IV, 9 \\
\hline Habibacysta tectata Head et al., 1989a & Htec & Plate I, 19-20 \\
\hline Hystrichosphaeropsis obscura Habib, 1972 & Hobs & Plate II, 1-5 \\
\hline Impagidinium elongatum sp. nov. & Ielo & Plate II, 6-20 \\
\hline $\begin{array}{l}\text { Labyrinthodinium truncatum Piasecki, } 1980 \\
\text { emend. de Verteuil and Norris, } 1996\end{array}$ & Ltru & Plate IV, 3-6 \\
\hline $\begin{array}{l}\text { Operculodinium? eirikianum Head et al., 1989a } \\
\text { emend. Head, } 1997\end{array}$ & Oeir & Plate I, 4-5 \\
\hline $\begin{array}{l}\text { Operculodinium piaseckii Strauss and Lund, } 1992 \\
\text { emend. de Verteuil and Norris, } 1996\end{array}$ & Opia & Plate I, 6-7 \\
\hline Operculodinium tegillatum Head, 1997 & Oteg & Plate I, 8-10 \\
\hline Palaeocystodinium spp. & Pspp & Plate IV, $13-15$ \\
\hline Pyxidinopsis vesiculata Head and Norris, 2003 & Pves & Plate I, 16-18 \\
\hline $\begin{array}{l}\text { Reticulatosphaera actinocoronata (Matsuoka, 1983) } \\
\text { Bujak and Matsuoka, } 1986\end{array}$ & Ract & Plate IV, 7-8 \\
\hline $\begin{array}{l}\text { Unipontidinium aquaeductus (Piasecki, 1980) } \\
\text { Wrenn. } 1988\end{array}$ & Uaqu & Plate I, 13-15 \\
\hline
\end{tabular}

ACRITARCH

Decahedrella martinheadii Manum, 1997

Dmar

Plate IV, 18-19

However, using such criteria to evaluate reworking in the older published literature is difficult because raw counts or quantitative data were seldom made available.

Another complicating factor is that rare or discontinuous occurrences, especially at high-latitude sites, may not represent reworking but relate to variable oceanographic/climatic conditions such as glacial/interglacial cycles. Thus, fixed-interval sampling will be biased towards colder conditions, and narrow intervals (e.g. interglacials) with high abundances of a warm-adapted species may not be sampled sufficiently. This introduces an unknown error into the calculations of ages for any bioevents, and HPOs and HCOs clearly must be treated with special caution in high-latitude regions.

\section{Results}

\subsection{Chronostratigraphic summary of sites used for comparison}

To test the biostratigraphic utility of bioevents calibrated in Hole 907A on a regional and supraregional scale, comparisons are made with the few relatively high-resolution Neogene palynostratigraphic studies from the North Atlantic region that have detailed and reliable magnetostratigraphy and/or independent biostratigraphy (Fig. 1). The age assignments of bioevents in the older literature have been revised where new chronostratigraphic control is available, and all datums are calibrated to the latest time scale, ATNTS 2004 (Lourens et al., 2005).

In general, Pliocene successions offer better magnetostratigraphic age control than Miocene successions, where magnetic polarity sequences tend to be complicated by hiatuses, drilling disturbances and high reversal frequencies. For the Pliocene, good paleomagnetic age control is available for Iceland Sea ODP Hole 987E (Channell et al., 1999b), Norwegian Sea ODP Site 642 (Bleil, 1989), eastern North
Atlantic DSDP Holes 610A (Clement and Robinson, 1987; De Schepper and Head, 2008) and 400/400A (Hailwood, 1979), central North Atlantic DSDP Hole 607/607A (Clement and Robinson, 1987), and western North Atlantic DSDP Hole 603C (Canninga et al., 1987). For the Miocene, magnetostratigraphic age control is provided only for Norwegian Sea ODP sites 642 and 643 (Bleil, 1989), and eastern North Atlantic IODP Site U1318 (Louwye et al., 2007b). At sites 642 and 643 , the magnetic polarity record (Bleil, 1989) is fragmented by hiatuses identified primarily by a radiolarian stratigraphy (Goll, 1989; Goll and Bjørklund, 1989) that has since been re-interpreted based on unpublished data (Goll, 1997 in Williams and Manum, 1999). However, some putative hiatuses have been questioned by Bruns et al. (1998) who in fact suspected them to represent artifacts of calcareous and biosiliceous microfossil preservation due to reduced sedimentation rates. Our study therefore relies primarily on the magnetostratigraphic interpretation of Bleil (1989). IODP Site U1318 provides a well-constrained magnetostratigraphy that covers the Lower through Middle Miocene (Louwye et al., 2007b).

Other North Atlantic sites used for comparison in this study are dated less accurately or less completely, either through low resolution of the magnetostratigraphy and supporting microfossil datums or because biostratigraphy is the only age control.

Of the many palynostratigraphic studies published on sequences from the marginal North Atlantic and adjacent basins, relatively few have been selected for comparison. The continuous Miocene successions from northern Italy alone have a first-order paleomagnetic and biostratigraphic calibration (Zevenboom, 1995). The datums defined for the on- and offshore eastern U.S.A. and adjacent continental margin (de Verteuil, 1996; de Verteuil and Norris, 1996; de Verteuil, 1997) have been widely accepted and frequently applied to European Neogene sequences because of their similar latitudinal position and comparable assemblages. However, while the U.S. continental margin and coastal plain sequences are placed within a detailed sequence stratigraphic framework, they have many hiatuses and lack the precise chronostratigraphic control of some deep-sea records.

The North Sea was a semi-enclosed basin connected only to the Nordic Seas during much of the Neogene (Rasmussen et al., 2008). A wealth of palynostratigraphic data has been compiled throughout the region in an attempt to correlate and date bioevents and zonations (for regional overviews see Head, 1998a; Louwye et al., 2000; Köthe, 2003; Louwye et al., 2004; Munsterman and Brinkhuis, 2004; Köthe, 2005; Köthe and Piesker, 2007; Louwye et al., 2007a; Dybkjær and Piasecki, 2010). However, zonations have been established using comprehensive but geographically restricted data sets partly based on multiple boreholes or sections that may not be applicable between regions, e.g. the Netherlands and Germany (Köthe and Andruleit, 2007), and regional correlations have been hampered by the paucity of continuous sequences and a scarcity of calcareous planktonic microfossils needed for independent control (for a detailed discussion see Head, 1998a; Köthe, 2005; Dybkjær and Piasecki, 2010). In the absence of such control, the Miocene dinocyst zonation established for the U.S. East Coast by de Verteuil and Norris (1996) has been used in Belgium (e.g. Louwye et al., 2000) and northern Germany (Köthe, 2003, 2005). For the North Sea Basin, Munsterman and Brinkhuis (2004) relied on a combination of stratigraphic data and the work of Zevenboom (1995) and de Verteuil and Norris (1996) for age-calibration of bioevents, and Donders et al. (2009) updated these ages to ATNTS 2004. In eastern England, the in-situ marine Miocene is missing, although a fragmentary Pliocene and Lower Pleistocene marine record has led to the definition of provisional highest occurrences and acme events for selected species (Head, 1998a). A comprehensive stratigraphic assessment of bioevents defined in the separate studies is required to establish useful datums for the entire southern North Sea Basin. In contrast, few data are available from the northern North Sea (Piasecki et al., 2002; Head et al., 2004). 


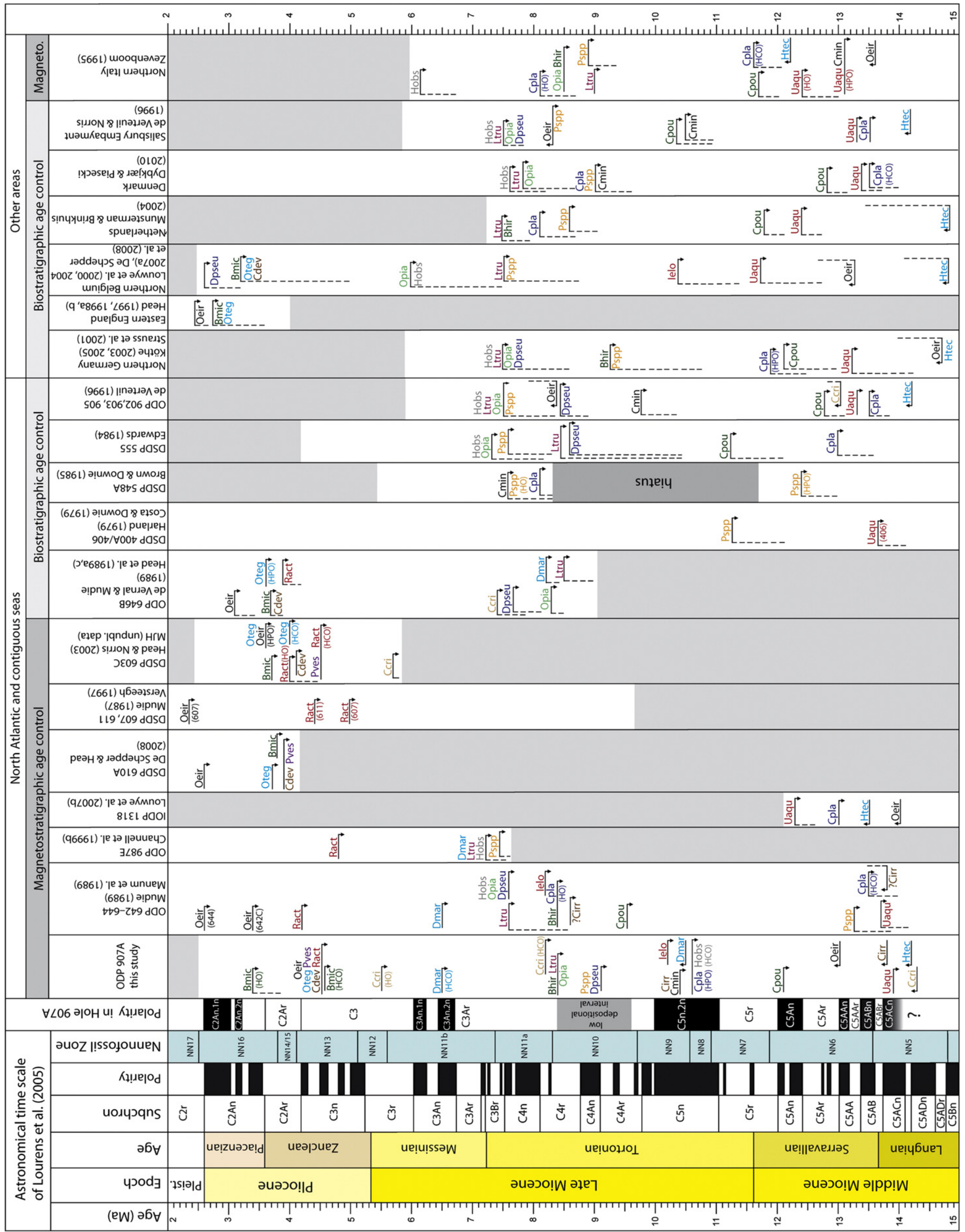


An unambiguous recalibration of datums identified from these studies is therefore not always possible, but approximate ages have been assigned below (and in Fig. 4) to species considered promising for future biostratigraphic investigations on a regional or supraregional scale.

\subsection{Magnetostratigraphic calibration of dinocyst events}

The studied section of Hole 907A yielded a diverse and wellpreserved dinocyst record, comprising at least 155 species belonging to at least 44 genera, and most of the 120 samples analyzed yielded enough dinocysts and Decahedrella martinheadii combined to enumerate 350 specimens. Counts in 21 samples ranged between 14 and 194 cysts and 16 samples are virtually barren $(<5$ cysts per slide). Most barren samples cluster between 100 and 103 mbsf in the Upper Miocene (c. 7.5-8.0 Ma). A second low-productivity interval ( $<9$ cysts per slide) is found in the Upper Pliocene between 2.6 and 3.3 Ma (49-62 mbsf). Reworking of pre-Miocene material is limited (M.S., unpubl. data).

For this study, we focussed on 20 morphologically distinctive dinocyst taxa and one acritarch species (Table 1), many of which are already recognized biostratigraphic markers for the Miocene and Pliocene in the North Atlantic and adjacent seas (e.g. Stover et al., 1996; Williams et al., 1998, 2004).

Poulsen et al. (1996) recorded most of the taxa discussed here, but usually in a few samples only. Moreover, the age assignments of their three provisional biozones are not consistent with age estimates calculated by Channell et al. (1999b) based on the well-defined magnetostratigraphy of ODP Hole 987E. Nonetheless, occurrences of important taxa reported by Poulsen et al. (1996) are discussed in the text where appropriate.

The datums identified in Hole 907A (Fig. 3) have been placed within a regional framework by comparison with suitable sites across the North Atlantic realm (Fig. 4). The source of dinocyst data, taxonomic information and the sample information used for the chronostratigraphic calibration of events at the various North Atlantic sites is given in Appendix A.

\section{Langhian (Middle Miocene)}

LO Cristadinium cristatoserratum (Plate IV, 10-12)

Occurrence: Sample 907A-23H-6, 97.5-99.5 cm; 215.30 mbsf.

Magnetostratigraphic calibration: Extrapolated from top of Subchron C5ABn through top of Subchron C5ACn.

Age assessment: $14.3 \mathrm{Ma}$ (mid-Langhian).

Discussion: The age of this datum should be regarded as a minimum owing to the rare and sporadic occurrence of this species in the lower part of Hole 907A.

This species has seldom been reported following its description by Head et al. (1989a) from ODP Hole 646B in the Labrador Sea. It extends to the base of Hole 646B, which is calibrated to the midTortonian calcareous nannofossil zone NN10 (Head et al., 1989c; Knüttel et al., 1989).

It has been reported sporadically from offshore New Jersey, western North Atlantic, with an LO established from one sample in the Upper Oligocene of ODP Hole 906A and an LO in the Middle Miocene dinocyst zone DN5 of ODP Hole 905A (c. 13 Ma, de Verteuil, 1996; Gartner and Shyu, 1996). In western North Atlantic DSDP Hole 603C, this species occurs at the base of the hole at $5.82 \mathrm{Ma}$ (upper Messinian) (M.J.H, unpubl. data; Canninga et al., 1987).
The only other published record of this species is from ODP Hole 908A, just west of Spitsbergen, where it was reported in a single sample from the lower Tortonian (Poulsen et al., 1996).

LO Habibacysta tectata (Plate I, 19-20)

Occurrence: Sample 907A-23H-3, 51.5-53.5 cm; 210.3 mbsf.

Magnetostratigraphic calibration: Extrapolated from top of Subchron C5ABn through top of Subchron C5ACn.

Age assessment: 14.2 Ma (mid-Langhian).

Discussion: Habibacysta tectata has a well-defined LO four samples above the base of Hole 907A.

This species has been reported frequently across the North Atlantic (see Head, 1994 and references therein). The LO obtained from our data is consistent with its LO from the continental slope off New Jersey (de Verteuil, 1996) and the Salisbury Embayment (de Verteuil and Norris, 1996) but is lower than that at eastern North Atlantic IODP Site U1318 (c. 13.5 Ma, lower Serravallian; Louwye et al., 2007b). In Baffin Bay ODP Hole 645E, the LO of Habibacysta tectata was recorded above the base of the combined calcareous nannofossil zones NN5 to NN15 (Head et al., 1989b; Knüttel et al., 1989) indicating an LO younger than 14.9 Ma. In Norwegian Sea ODP Holes 642B and 643C, it was possibly recorded from the Middle Miocene (as Tectatodinium pellitum and Dinocyst sp. 1 in Mudie, 1989; Head, 1994). According to revised Re-Os isochron ages for IODP Hole M0002A (Poirier and Hillaire-Marcel, 2011), it has an LO at c. $15 \mathrm{Ma}$ in the central Arctic Ocean (Expedition 302 Scientists, 2006), whereas ${ }^{10} \mathrm{Be}$ isotope stratigraphy (Frank et al., 2008) indicates an age of c. $12.9 \mathrm{Ma}$.

In the southern North Sea Basin, the LO of H. tectata is not well constrained but possibly lies within the lower part of calcareous nannofossil zone NN5 in northern Germany (as Filisphaera minuta in Strauss et al., 2001; see comments in Jiménez-Moreno et al., 2006). For two wells in northern Germany, Köthe and Piesker (2007) assigned the LO of $H$. tectata to the dinocyst zone DN8 (lower Tortonian) of de Verteuil and Norris (1996). Köthe (2003) attributed the late appearance of this and several other species to a strong facies-related control on bioevents.

In Belgium, the LO of Habibacysta tectata is within the mid-Langhian (Louwye et al., 2000) and below the $\mathrm{HO}$ of Distatodinium paradoxum in contrast to the succession observed by de Verteuil and Norris (1996) for the eastern U.S.A. However, it should be noted that in Belgium (Louwye et al., 2000) as well as elsewhere (e.g. de Verteuil and Norris, 1996; Munsterman and Brinkhuis, 2004) the LO of $H$. tectata is slightly higher than that of Unipontidinium aquaeductus which is provisionally constrained at 15.1-14.8 Ma (mid-Langhian; see discussion in JiménezMoreno et al., 2006).

Based on a subsurface investigation of the Netherlands, the LO of Habibacysta tectata was recorded within southern North Sea Miocene zone 7 of Munsterman and Brinkhuis (2004) which has an age of c. 15.0 Ma (mid-Langhian) at the base (D. Munsterman, pers. commun. 2012).

The relatively high LO of Habibacysta tectata in northern Italy (Subchron C5An, c. 12.2 Ma, upper Serravallian; Zevenboom, 1995) may not reflect the true LO because it was present since at least $c$. 14.8 Ma (mid-Langhian) in the Vienna and Pannonian basins (Jiménez-Moreno et al., 2006), and these were connected to the northern Italian sites during most of the Middle and Late Miocene (Rögl, 1999).

Jiménez-Moreno et al. (2006) considered records older than calcareous nannofossil zone NN5 to result from caving or other contamination. This is presumably also true for Lower Miocene

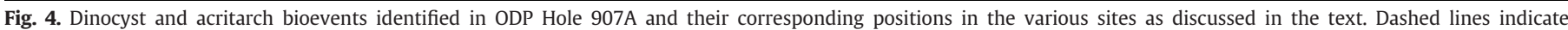

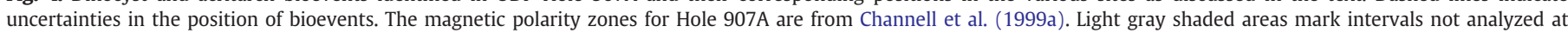
the various sites. Dark gray shaded area indicates hiatus. The names of species codes are given in Table 1. 
occurrences in Denmark (Dybkjær, 2004; for a revised age assignment of formations see Dybkjær and Piasecki, 2010).

HO Unipontidinium aquaeductus (Plate I, 13-15)

Occurrence: Sample 907A-21H-6, 2-4 cm; 195.3 mbsf.

Magnetostratigraphic calibration: Extrapolated from top of Subchron C5ABn through top of Subchron C5ACn.

Age assessment: $13.9 \mathrm{Ma}$ (late Langhian).

Discussion: Poulsen et al. (1996) reported a comparable stratigraphic range for Unipontidinium aquaeductus in Hole 907A from Section 907A-23H-4 (211.50 mbsf) up to Sample 21H-CC (197.38 mbsf).

This species has a rather poorly constrained $\mathrm{HO}$ in most sites selected for comparison, and the age appears to vary considerably between regions (Fig. 4). An HO is observed in the upper Langhian for Hole 907A but slightly higher, near the Langhian/Serravallian boundary, in deep-water sites in the Norwegian Sea (ODP Hole 643A, Manum et al., 1989; Goll unpubl. data in Williams and Manum, 1999) and central North Atlantic (DSDP Site 406, Costa and Downie, 1979; Müller, 1979). A younger HO at c. 13.3 Ma (lower Serravallian) has been reported from the eastern U.S.A. and the continental slope off New Jersey (de Verteuil, 1996; de Verteuil and Norris, 1996); and for eastern North Atlantic IODP Site U1318, the HO is within Subchron C5An.2n at c. $12.3 \mathrm{Ma}$, which is notably above the LO of Cannosphaeropsis passio (Louwye et al., 2007b). A similar overlap has been noted in Belgium (Louwye et al., 2000), but in the eastern U.S.A. (de Verteuil and Norris, 1996) and elsewhere (e.g. northern Germany; Strauss et al., 2001; Köthe and Piesker, 2007), these two species have their stratigraphic ranges separated by a narrow interval represented by the dinocyst zone DN6 of de Verteuil and Norris (1996). This either implies strong ecological control on the distribution of one or both species, or reworking of Unipontidinium aquaeductus into this atypical stratigraphic position. Mudie (1987) illustrated two specimens from the Upper Miocene and Lower Pliocene of central North Atlantic DSDP Sites 607 and 611, but neither is attributable to U. aquaeductus (de Verteuil and Norris, 1996).

For the Netherlands, Munsterman and Brinkhuis (2004) recorded an $\mathrm{HO}$ within the mid-Serravallian, and Donders et al. (2009) calculated an age of $12.42 \mathrm{Ma}$ which is comparable to that at IODP Site U1318. In Belgium it appears to range into the uppermost Serravallian (Louwye et al., 2000), although there is little independent stratigraphic control for this part of the sequence. In northern Germany, it has an $\mathrm{HO}$ in the upper Langhian or lower Serravallian (Strauss et al., 2001), whereas Dybkjær and Piasecki (2010) recorded an HO within the lower Serravallian in Denmark but stated that their Unipontidinium aquaeductus zone is generally condensed in distal depositional settings. In Hungary, the $\mathrm{HO}$ is within the lower Serravallian (Jiménez-Moreno et al., 2006). As noted by JiménezMoreno et al. (2006), Zevenboom (1995) recorded the highest persistent occurrence of $U$. aquaeductus in the middle of his subzone Oei, an event calibrated to Subchron C5AAn and dated at c. 13.1 Ma (lower Serravallian). Rare and sporadic occurrences above this datum, in both the Cassinasco and Mazzapiedi sections (Zevenboom, 1995) and occurring as high as $12.0 \mathrm{Ma}$ (upper Serravallian) in the Cassinasco section, were suspected by Jiménez-Moreno et al. (2006) of being reworked.

LO Cerebrocysta irregulare sp. nov. (Plate III, 11-20)

Occurrence: Sample 907A-21H-2, 97.5-99.5 cm; 190.3 mbsf.

Magnetostratigraphic calibration: Extrapolated from top of Subchron C5ABn through top of Subchron C5ACn.

Age assessment: $13.8 \mathrm{Ma}$ (late Langhian).

Discussion: Cerebrocysta irregulare has a rare but persistent occurrence through the lower part of its range in Hole 907A.

Tectatodinium sp. 4 of Manum et al. (1989) compares favorably with Cerebrocysta irregulare (see Systematic paleontology), and has an LO near the Langhian/Serravallian boundary in Norwegian Sea
ODP Hole 643A (Manum et al., 1989; Goll unpubl. data in Williams and Manum, 1999). There are no other known records of this species.

\section{Serravallian (Middle Miocene)}

LO Operculodinium? eirikianum (Plate I, 4-5)

Occurrence: Sample 907A-18H-1, 20-22 cm; 159.5 mbsf.

Magnetostratigraphic calibration: Base of Subchron C5Ar (interpolation between base of Subchron $\mathrm{C} 5 \mathrm{Ar}$ and base of Subchron C5An.2n).

Age assessment: 13.0 Ma (early Serravallian).

Discussion: This species has an LO within Subchron C5ACn at c. 14.0 Ma (upper Langhian) at eastern North Atlantic IODP Site U1318 (Louwye et al., 2007b), and the sporadic occurrence at this site suggests that its true LO may be yet lower. For the Cassinasco section of northern Italy, Zevenboom (1995) reported an LO at the top of Subchron C5ABr at c. $13.6 \mathrm{Ma}$ (lowermost Serravallian).

Elsewhere, the LO of Operculodinium? eirikianum is not constrained directly to magnetostratigraphy and therefore is subject to greater uncertainty. For the Salisbury Embayment of eastern U.S.A., de Verteuil and Norris (1996) recorded the LO at the base of their zone DN9 which is calibrated to the base of calcareous nannofossil zone NN11 at c. $8.3 \mathrm{Ma}$ (upper Tortonian). For offshore New Jersey, U.S.A. the LO was also recorded within zone DN9 (de Verteuil, 1996).

In Labrador Sea ODP Hole 646B (Head et al., 1989c) it was found in the lowermost sample of the cored interval within the mid-Tortonian (calcareous nannofossil zone NN10, Knüttel et al., 1989), which thus unlikely reflects the real LO.

Its range base in the Norwegian Sea (ODP Leg 104) is poorly known because Operculodinium? eirikianum had not been described when the study was undertaken (Manum et al., 1989), and both 0. ? eirikianum and the superficially similar species 0 . longispinigerum were reported under the latter name. Head (in Head and Wrenn, 1992) confirmed the presence of 0 . longispinigerum in the Lower Miocene of ODP Hole 643A, but one specimen illustrated as O. longispinigerum by Manum et al. (1989, pl. 14, fig. 8) from the Upper Miocene or higher in ODP Hole 642C was reassigned to 0.? eirikianum by Head (in Head and Wrenn, 1992).

Operculodinium? eirikianum has an LO in the Middle Miocene of the Iberia Abyssal Plain, eastern North Atlantic, according to McCarthy and Mudie (1996), but the morphological description given by these authors indicates that some specimens were misidentified.

In the North Sea Basin, Operculodinium? eirikianum occurs in the Middle Miocene of Belgium in deposits assigned to the upper part of zone DN5 of de Verteuil and Norris (1996) and probably of mid-Serravallian age (Louwye, 2005). For the Nieder Ochtenhausen borehole of northern Germany, Strauss et al. (2001) assigned the LO to their zone $\mathrm{Cpl}$ which is calibrated directly to the lower part of calcareous nannofossil zone NN5, indicating an upper Langhian age for this datum.

\section{HO Cerebrocysta poulsenii (Plate IV, 1-2)}

Occurrence: Sample 907A-16H-2, 91.5-93.5 cm; 142.7 mbsf.

Magnetostratigraphic calibration: Upper part of Subchron C5An (interpolation between base of Subchron C5An.2n and base of Subchron C5r).

Age assessment: $12.1 \mathrm{Ma}$ (late Serravallian).

Discussion: This species, recorded in the older literature as Gen. et sp. indet. of Piasecki (1980), has a diachronous HO in Iceland Sea Hole 907A and Norwegian Sea ODP Hole 643A (Subchron C4Ar, c. 9.5 Ma; mid-Tortonian; Manum et al., 1989; Bleil, 1989). In eastern North Atlantic DSDP Site 555, its HO has been observed in the upper Serravallian or lower Tortonian (Edwards, 1984; Backman, 1984). Its $\mathrm{HO}$ has also been recorded from the Salisbury Embayment, eastern U.S.A. within the lower part of zone DN8 (c. $10.4 \mathrm{Ma}$, lower Tortonian; de Verteuil and Norris, 1996), and it has a well defined 
HO within zone DN6 (mid-Serravallian) of ODP Hole 905A on the New Jersey continental rise (de Verteuil, 1996; Gartner and Shyu, 1996). A single record in ODP Hole 903A on the New Jersey continental shelf within zone DN9 (upper Tortonian, de Verteuil, 1996) is suspected of being reworked based on its unusually high stratigraphic position. Head et al. (1989b) reported rare occurrences of specimens assigned to a "Gen. et sp. indet of Piasecki, 1980 group" from the Lower, Middle and lower Upper? Miocene in Baffin Bay ODP Hole 645E. Although this group may include species other than Cerebrocysta poulsenii, the highest unquestioned occurrence of this group in Hole 645E (Head et al., 1989b, pl. 12, figs. 10, 11) is here confirmed as being of $C$. poulsenii.

For Denmark the HO is recorded at c. $12.8 \mathrm{Ma}$, mid-Serravallian (Dybkjær and Piasecki, 2010); and for the Netherlands at c. $11.8 \mathrm{Ma}$, upper Serravallian (Munsterman and Brinkhuis, 2004; Donders et al., 2009). Its HO has also been reported from the Serravallian of northern Germany (Strauss et al., 2001), from the lower Serravallian of central Europe (Jiménez-Moreno et al., 2006), and from northern Italy in Subchron C5r.3r at c. $11.7 \mathrm{Ma}$, upper Serravallian (as "Imperfectodinium septatum" in Zevenboom, 1995).

\section{Tortonian (Late Miocene)}

HO Cleistosphaeridium placacanthum (Plate IV, 16-17) Occurrence: Sample 907A-14H-1, 141.5-143.5 cm; 122.7 mbsf. Magnetostratigraphic calibration: Middle of Subchron C5n.2n (interpolation between base and top of Subchron C5n.2n). Age assessment: $10.6 \mathrm{Ma}$ (early Tortonian).

Discussion: For the Salisbury Embayment, eastern U.S.A., de Verteuil and Norris (1996) recorded an HO at c. 13.5 Ma (lower Serravallian), this datum defining the top of their zone DN5. In ODP Hole 905A offshore New Jersey, the HO has been observed at the same stratigraphic position (de Verteuil, 1996). At eastern North Atlantic IODP Site U1318 (Louwye et al., 2007b) and DSDP Site 555 (Edwards, 1984; Backman, 1984), the HCO and HO respectively are both at c. 13.0 Ma, with Louwye et al. (2007b) reporting only rare and isolated occurrences above 13.0 Ma, whereas in DSDP Hole 548A, Cleistosphaeridium placacanthum appears to extend into the Upper Miocene (as Areoligera senonensis complex in Brown and Downie, 1985; Müller, 1985) although an HCO/HPO cannot be defined.

De Verteuil and Norris (1996) considered a rare Upper Miocene record from Norwegian Sea ODP Hole 643A (c. 8.4 Ma, Manum et al., 1989; Bleil, 1989) to represent reworking, which we accept, but Manum et al. (1989) also recorded an HCO at the top of their Unipontidinium aquaeductus zone, dated to c. $13.5 \mathrm{Ma}$ (Goll unpubl. data in Williams and Manum, 1999) in the lower Serravallian which is presumably in place.

For Denmark, Dybkjær and Piasecki (2010) noted an HO at the top of their Amiculosphaera umbraculum zone (c. 8.9 Ma, mid-Tortonian) and that the highest abundant occurrence of Cleistosphaeridium placacanthum is near the top of their Unipontidinium aquaeductus zone (c. $13.3 \mathrm{Ma}$, lower Serravallian).

A comparatively high $\mathrm{HO}$ at c. 8.1 Ma is given for the Netherlands (Munsterman and Brinkhuis, 2004; Donders et al., 2009) but no quantitative data are available to evaluate whether this might be attributable to reworking. In northern Germany, the HPO of Cleistosphaeridium placacanthum is well defined (Strauss et al., 2001), and occurs below the LO of Cannosphaeropsis passio as it does in the eastern U.S.A. (de Verteuil and Norris, 1996) and eastern North Atlantic (Site U1318, Louwye et al., 2007b), implying a midto upper Serravallian age.

In northern Italian sections studied by Zevenboom (1995), the HCO is at c. $12.1 \mathrm{Ma}$ (Subchron C5An.1n, upper Serravallian) in the Mazzapiedi section, but Cleistosphaeridium placacanthum is common to the top of the Cassinasco section, which is dated to c. 12.0-11.6 Ma (Subchron C5r.3r). Rare and sporadic occurrences at the top of the
Mazzapiedi section (c. 8.0 Ma, uppermost Tortonian) might represent reworking.

HCO Hystrichosphaeropsis obscura (Plate II, 1-5) Occurrence: Sample 907A-14H-1, 141.5-143.5 cm; 122.7 mbsf. Magnetostratigraphic calibration: Middle of Subchron C5n.2n (interpolation between base and top of Subchron C5n.2n). Age assessment: $10.6 \mathrm{Ma}$ (early Tortonian).

Discussion: This species has a rare and somewhat sporadic occurrence throughout its range in Hole 907A. Elevated numbers occur in one sample here designated as the HCO, which is clearly a tentative datum. Above this, isolated specimens might be in place judging from the $\mathrm{HO}$ of this species elsewhere, although there is some evidence for ecological exclusion above the HCO (see Section 4.1).

Hystrichosphaeropsis obscura was first described from the Upper Miocene of the western North Atlantic (Habib, 1972). In Norwegian Sea ODP Hole 643A, its HO is at c. 7.6 Ma (Subchron C4n.1n, Mudie, 1989; Manum et al., 1989; Bleil, 1989), and is at c. 7.2 Ma (Subchron C3Bn, Channell et al., 1999b) in Iceland Sea ODP Hole 987E (M. Smelror, pers. commun., 2007). De Verteuil and Norris (1996) used the HO of $\mathrm{H}$. obscura to define the top of their DN9 zone in the upper Tortonian (c. 7.5 Ma) of the Salisbury Embayment, eastern U.S.A. A similar position at the top of zone DN9 was reported for the HO from the continental margin of New Jersey (de Verteuil, 1996; Gartner and Shyu, 1996). In eastern North Atlantic DSDP Site 555, the HO was reported within the lower part of nannofossil zone NN11 (upper Tortonian, Edwards, 1984; Backman, 1984), whereas $H$. obscura ranges to the nannofossil zone boundary NN5/6 in DSDP Hole 548A (Brown and Downie, 1985; Müller, 1985), although here the $\mathrm{HO}$ is probably lost within an apparent hiatus separating the upper Middle Miocene from middle Upper Miocene (Snyder et al., 1985). For eastern North Atlantic IODP Holes 1318B and C, Louwye et al. (2007b) reported $H$. obscura in low numbers fairly persistently throughout a Miocene succession that extends into the upper Serravallian. From northern North Atlantic DSDP Hole 408, Reykjanes Ridge, Engel (1992) recorded two isolated occurrences from foraminiferal zone N16 within the mid-Tortonian (Poore, 1979). Mudie (1987) found rare specimens in the Upper Pliocene of central North Atlantic DSDP Site 611 but attributed them to reworking.

In the North Sea Basin the HO of Hystrichosphaeropsis obscura seems to be in the upper Tortonian of both Denmark (Dybkjær and Piasecki, 2010) and Germany (Köthe, 2005; Köthe and Andruleit, 2007), and Louwye et al. (2007a) recorded H. obscura in the Belgian Kasterlee Formation which is indirectly dated at c. 7.5-6.0 Ma (uppermost Tortonian-mid-Messinian). An even younger Early Pliocene record in Dutch wells (Munsterman and Brinkhuis, 2004) is in conflict with its Late Miocene disappearance elsewhere and considered reworked (D. Munsterman, pers. commun., 2012).

For northwestern Italy, Zevenboom (1995) gave an undifferentiated mid-Messinian age for the $\mathrm{HO}$ in the Mazzapiedi/Perleto section. Based on the astronomical calibration of sedimentary cycles on Crete (Greece), Santarelli et al. (1998) recorded the HO in the lower Messinian at c. 6.8 Ma. From the Atlantic coast of Morocco, its HO is in the upper part of Subchron C3r (c. $5.3 \mathrm{Ma}$, uppermost Messinian) just below the Miocene/Pliocene boundary (Warny and Wrenn, 2002).

LO Decahedrella martinheadii (Plate IV, 18-19)

Occurrence: Sample 907A-13H-7, 31.5-33.5 cm; 121.1 mbsf. Magnetostratigraphic calibration: Middle of Subchron C5n.2n (interpolation between base and top of Subchron C5n.2n). Age assessment: $10.5 \mathrm{Ma}$ (early Tortonian).

Discussion: This marine acritarch is restricted to the Upper Miocene and possible upper Middle Miocene, and was endemic to the high-latitude North Atlantic region and Arctic Ocean (Matthiessen et al., 2009b). Matthiessen et al. (2009b) compared its LO at numerous high northern-latitude sites and suggested an age no greater than 
13-12 Ma (Serravallian), with the oldest firm record at c. 11.0 Ma (lower Tortonian) from ODP Hole 909C in the Fram Strait. Matthiessen et al. (2009b) also noted differences in its position between sites, even when allowing for uncertainties in age control. At Site 907 the LO would be at c. $10.1 \mathrm{Ma}$ based on the observations of Poulsen et al. (1996) but here we record a slightly older LO at 10.5 Ma.

HO Cordosphaeridium minimum sensu Benedek and Sarjeant, 1981 (Plate I, 1-3)

Occurrence: Sample 907A-13H-5, 12-14 cm; 117.9 mbsf.

Magnetostratigraphic calibration: Middle of Subchron C5n.2n (interpolation between base and top of Subchron C $5 n .2 n$ ).

Age assessment: $10.4 \mathrm{Ma}$ (early Tortonian).

Discussion: The stratigraphic range of Cordosphaeridium minimum sensu Benedek and Sarjeant (1981) is somewhat complicated by taxonomic uncertainties, although most Miocene records apparently represent this taxon rather than C.? minimum (Morgenroth) Benedek 1972, which was described from the Lower Eocene of Germany as having coarsely fibrous to areolate body surface (Head et al., 1989b).

For Hole 907A, Poulsen et al. (1996) reported an isolated rare occurrence within Section 907A-12H-2 (104.08 mbsf, equivalent to an age of $8.4 \mathrm{Ma}$ ), and a common occurrence in Sample $13 \mathrm{H}-\mathrm{CC}$ (121.62 mbsf, 10.5 Ma) which is close to our own observed HO for this hole.

The HO varies widely across the North Atlantic and adjacent seas, ranging from c. $13.1 \mathrm{Ma}$ (lower Serravallian) in northern Italy (Zevenboom, 1995) to upper Tortonian in the eastern North Atlantic (Brown and Downie, 1985; Müller, 1985).

Our observations for Hole 907A are consistent with those of the Salisbury Embayment, eastern U.S.A. where this species disappeared at c. $10.5 \mathrm{Ma}$ (lower Tortonian; de Verteuil and Norris, 1996), and de Verteuil (1996) recorded a similar age within the middle of zone DN8 (mid-Tortonian; Gartner and Shyu, 1996) for its HO in the continental slope off New Jersey. For eastern North Atlantic IODP Site U1318, Louwye et al. (2007b) recorded this species rarely but persistently throughout the investigated Lower and Middle Miocene sequence which extends to $12.1 \mathrm{Ma}$ (upper Serravallian).

Dybkjær and Piasecki (2010) gave an age of c. 9.0 Ma (midTortonian) for its HO in Denmark, and Strauss et al. (2001) recorded this species from the Upper Miocene of northern Germany. From subsurface wells in the Netherlands, this species was recorded through and above southern North Sea Miocene zone 14 (c. 7.4-8.1 Ma; upper Tortonian) by Munsterman and Brinkhuis (2004).

HO Cerebrocysta irregulare sp. nov. (Plate III, 11-20)

Occurrence: Sample 907A-13H-5, 12-14 cm; 117.9 mbsf.

Magnetostratigraphic calibration: Middle of Subchron C5n.2n (interpolation between base and top of Subchron C5n.2n).

Age assessment: $10.4 \mathrm{Ma}$ (early Tortonian).

Discussion: An HO for this species is presently known with certainty only from this study. However, we tentatively synonymise this species with Tectatodinium sp. 4 of Manum et al. (1989), which has a magnetostratigraphically-calibrated $\mathrm{HO}$ at c. $8.6 \mathrm{Ma}$ (mid-Tortonian) in Norwegian Sea ODP Hole 643A (Subchron C4r.2r, Manum et al., 1989; Bleil, 1989).

HO Impagidinium elongatum sp. nov. (Plate II, 6-20; Figs. 6, 7) Occurrence: Sample 907A-13H-2, 142-144 cm; 114.7 mbsf.

Magnetostratigraphic calibration: Interpolation between top C $5 \mathrm{n} .2 \mathrm{n}$ and top C3Ar.

Age assessment: $10.2 \mathrm{Ma}$ (mid-Tortonian).

Discussion: This species has a magnetostratigraphically-calibrated HO in Subchron C4r.1r at c. 8.2 Ma in Norwegian Sea ODP Hole 643A (as Impagidinium sp. 3 in Manum et al., 1989; Bleil, 1989). Impagidinium sp. 1 and 2 of Anstey (1992) from Baffin Bay ODP Hole 645E are probably conspecific with Impagidinium elongatum. Both morphotypes were recorded as rare to occasional, and confined to the lowest zone in Anstey's study, which is dated as late Middle? to early Late Miocene based on dinocyst biostratigraphy. It has been recorded also from the lower Tortonian Deurne Sands Member of the Diest Formation in Belgium (as Impagidinium sp. 1 in Louwye, 2002). Impagidinium sp. 1 of Manum et al. (1989) is questionably synonymized with I. elongatum, and has an $\mathrm{HO}$ in the upper Middle Miocene of Norwegian Sea ODP Hole 643A (Manum et al., 1989; Goll unpubl. data in Williams and Manum, 1999).

HO Dapsilidinium pseudocolligerum (Plate IV, 9)

Occurrence: Sample 907A-12H-4, 77-79 cm; 107.6 mbsf.

Magnetostratigraphic calibration: Interpolation between top C5n.2n and top C3Ar.

Age assessment: 9.1 Ma (mid-Tortonian).

Discussion: This species has been reported commonly from the Miocene across the North Atlantic region along with Dapsilidinium pastielsii. It differs from $D$. pastielsii only by having processes that are somewhat longer, narrower and more widely separated (Stover, 1977) and hence rather less expanded proximally. However, McCarthy and Mudie (1996) noted that there may be intergrades between these species, and we follow de Verteuil and Norris (1996) and Head and Westphal (1999) in not differentiating them in the Neogene literature.

For Hole 907A, Poulsen et al. (1996) reported an HO within section 12H-6 (109.99 mbsf, 9.6 Ma), which is slightly lower than our own observation. In the Norwegian Sea, it has a magnetostratigraphically calibrated $\mathrm{HO}$ at c. 7.6 Ma in ODP Hole 643A (Subchron C4n.1n; Mudie, 1989; Manum et al., 1989; Bleil, 1989). It has also been identified in ODP Hole $642 \mathrm{C}$ but its true $\mathrm{HO}$ is probably lost within a hiatus (Mudie, 1989; Manum et al., 1989; Bleil, 1989). In Labrador Sea ODP Hole 646B, this species has an HO within calcareous nannofossil zone NN11a (upper Tortonian, Head et al., 1989c; Knüttel et al., 1989 ) but that record is based on sporadic occurrences; and it occurs in the lower Tortonian of Davis Strait (Piasecki, 2003) although age control is poor at this site. In eastern North Atlantic DSDP Site 555, it has an $\mathrm{HO}$ within combined calcareous nannofossil zone NN9/10 (lower to mid-Tortonian, Edwards, 1984; Backman, 1984). Engel (1992) observed the HO of this species in the Upper Miocene both of the Bay of Biscay (Müller, 1979) and Reykjanes Ridge (Poore, 1979). From the Iberia Abyssal plain, an early HO has been observed within the upper part of calcareous nannofossil zone NN2 (mid-Burdigalian, McCarthy and Mudie, 1996; de Kaenel and Villa, 1996). For the Salisbury Embayment, eastern U.S.A., de Verteuil and Norris (1996) reported its HO at the top of their zone DN9 dated to c. 7.5 Ma (upper Tortonian). An HO at the top of zone DN8 has been reported from the continental slope off New Jersey (upper Tortonian, de Verteuil, 1996; Gartner and Shyu, 1996), whereas it is still present in the Lower Pleistocene of western North Atlantic DSDP Site 603C (M.J.H., unpubl. data; Canninga et al., 1987). Moreover, it is sporadically abundant in the Upper Pliocene or Lower Pleistocene of the Gulf of Mexico (as Dapsilidinium sp. A, Wrenn and Kokinos, 1986; Aubry, 1993) and ranges at least into the Lower Pleistocene of the Great Bahama Bank (Head and Westphal, 1999; Eberli et al., 1997).

In northern Germany, the HO has been placed at the top of zone DN9 (upper Tortonian, Köthe, 2003; Köthe and Piesker, 2007) whereas in Belgium it is as high as the mid- to Upper Pliocene (Louwye et al., 2004; De Schepper et al., 2008), although both studies have poor independent age control.

HO Palaeocystodinium spp. (Plate IV, 13-15)

Occurrence: Sample 907A-12H-3, 127-129 cm; 106.6 mbsf.

Magnetostratigraphic calibration: Interpolation between top C $5 n .2 n$ and top C3Ar.

Age assessment: 8.9 Ma (mid-Tortonian). 
Discussion: Palaeocystodinium golzowense was first described from the upper Paleogene of Germany by Alberti (1961), and was subsequently reported widely from the Miocene of the North Atlantic region and elsewhere, although reports of Palaeocystodinium species in open nomenclature increasingly acknowledged variations in morphology. In an attempt to explain this diversity, Strauss et al. (2001) proposed a phylogenetic lineage in which the ancestral $P$. golzowense gave rise to three new species that extended into the Middle Miocene (P. miocaenicum) and Late Miocene (P. minor and P. powellii). Some details of this lineage have since been questioned (Soliman et al., 2012). Meanwhile, Zevenboom and Santarelli (in Zevenboom, 1995) had already proposed two new manuscript names, "P. striatogranulosum" and " $P$. ventricosum", which subsequently found their way into the Miocene literature. To facilitate comparison between our Site 907 records and those elsewhere, particularly in the older literature, we have chosen simply to refer to the various species collectively as Palaeocystodinium spp.

Palaeocystodinium spp. is ubiquitous in the North Atlantic region and has been recorded from most sites considered here. For the Salisbury Embayment, eastern U.S.A., de Verteuil and Norris (1996) recorded its $\mathrm{HO}$ at the top of their zone DN8, which is dated at c. 8.3 Ma (upper Tortonian). For the continental slope and rise off New Jersey it extends into zone DN9, which has a range of c. 8.3-7.5 Ma (de Verteuil, 1996). It extends into the Upper Miocene of the Davis Strait (Piasecki, 2003) and possibly also of Baffin Bay (Head et al., 1989b) but age control is poor at both sites. For Iceland Sea ODP Hole 987E, an HO is recorded within the upper Tortonian at c. $7.4 \mathrm{Ma}$ (M. Smelror, pers. commun., 2007; Channell et al., 1999b), although this species was recorded at the base of the cored interval, so it is impossible to know whether the HO represents a continuous or isolated occurrence. Within the high-latitude North Atlantic region, the lowest HO recorded is from ODP Site 643 in the Norwegian Sea (Manum et al., 1989) and has an estimated age of c. 13.6 Ma (lower Serravallian). According to the magnetostratigraphy of Bleil (1989), this event coincides with a hiatus, although a condensed section has also been proposed (Bruns et al., 1998). Without other chronostratigraphic evidence available, the age of this $\mathrm{HO}$ is based on the unpublished data of Goll (in Williams and Manum, 1999) and should be treated with caution.

For eastern North Atlantic IODP Site U1318, it occurs mostly in low numbers throughout the Lower and Middle Miocene sequence studied by Louwye et al. (2007b), which extends to $12.1 \mathrm{Ma}$ (upper Serravallian). A relatively high $\mathrm{HO}$ is recorded in eastern North Atlantic DSDP Site 555 (upper Tortonian, Edwards, 1984; Backman, 1984) and eastern North Atlantic DSDP Site 548 (upper Tortonian, Brown and Downie, 1985; Müller, 1985). At the latter site, an apparent hiatus of c. 5.0 Ma separates the upper Middle Miocene from middle Upper Miocene (Snyder et al., 1985) and therefore the HPO (mid-Serravallian, Müller, 1985) from the HO, which is marked by a single occurrence only and hence is potentially reworked. In this context, the true upper range is probably lost within the hiatus. However, the HPO is somewhat in the range of the single occurrence recorded at the nearby DSDP Site 400 (upper Serravallian-lower Tortonian, Harland, 1979; Müller, 1979). At Site 555, it is recorded persistently up to the level of its HO (Edwards, 1984), which suggests that these specimens are in place. However, the large sample spacing and uncertainties in the biostratigraphic age control (Backman et al., 1984) may account for the observed differences.

Within Europe, the HO has been recorded at c. 9.0 Ma in Denmark (Dybkjær and Piasecki, 2010), c. 8.7 Ma in the Netherlands (Munsterman and Brinkhuis, 2004; Donders et al., 2009), and is placed within the mid-Tortonian (Louwye et al., 1999) or probable mid- to upper Tortonian (Louwye, 2002) in Belgium, and lower or middle Tortonian of northern Germany (Strauss et al., 2001); although these records lack precise independent age control. In the Mazzapiedi section of northern Italy, the HO occurs within the middle of Subchron C4An at c. 8.9 Ma (mid-Tortonian) although occurrences throughout this Serravallian-Tortonian section are rare and sporadic (Zevenboom, 1995).

HO Labyrinthodinium truncatum (Plate IV, 3-6)

Occurrence: Sample 907A-12H-2, 68-70 cm; 104.5 mbsf.

Magnetostratigraphic calibration: Interpolation between top $\mathrm{C} 5 \mathrm{n} .2 \mathrm{n}$ and top C3Ar.

Age assessment: $8.4 \mathrm{Ma}$ (late Tortonian).

Discussion: The most common morphotype represented in Hole 907A has processes/ridges that are strongly expanded distally. This morphotype was recorded from the Miocene of the Norwegian Sea (as Labyrinthodinium cf. truncatum in Manum et al., 1989, pl. 12, figs. 9, 10) and Baffin Bay (as L. cf. truncatum in Head et al., 1989b, pl. 10, figs. 2, 3). Because this morphotype intergrades with the more typical specimens in our material, and is not appreciably different from those illustrated, for example, from the Salisbury Embayment, eastern U.S.A. (as L. truncatum subsp. truncatum in de Verteuil and Norris, 1996, pl. 15, figs. 9-20), we include it within L. truncatum.

In Hole 907A, its $\mathrm{HO}$ is slightly higher than that reported by Poulsen et al. (1996) but agrees with the high-latitude record of Labrador Sea ODP Hole 646B (upper part of calcareous nannofossil zone NN10, c. 8.9-8.5 Ma, Head et al., 1989c; Knüttel et al., 1989). In Norwegian Sea ODP Hole 643A, it has an HO at c. 7.6 Ma (Subchron C4r.1n; as Labyrinthodinium cf. truncatum in Mudie, 1989; Manum et al., 1989; Bleil, 1989), although its HCO is at c. 8.6 Ma (Subchron C4r.2r, Manum et al., 1989; Bleil, 1989) and it is unclear whether the datum at c. 7.6 Ma represents reworking. In Iceland Sea ODP Hole 987E, the HO is magnetostratigraphically-calibrated to Subchron C3Bn (c. 7.2 Ma, Channell et al., 1999b), although no quantitative data are available to judge whether this relatively high position relates to a persistent or sporadic occurrence. In eastern North Atlantic DSDP Hole 555, the HO has been recorded in the combined nannofossil zone NN9/10 (mid-Tortonian, Edwards, 1984; Backman, 1984).

In the Salisbury Embayment, eastern U.S.A., Labyrinthodinium truncatum has an HO at the top of zone DN9 which is dated at c. 7.5 Ma (de Verteuil and Norris, 1996), and it similarly ranges to the top of DN9 on the continental slope off New Jersey (upper Tortonian, de Verteuil, 1996; Gartner and Shyu, 1996).

In Belgium, the Netherlands, and northern Germany, this datum is at about the same stratigraphic level (Louwye et al., 1999; Köthe, 2003; Munsterman and Brinkhuis, 2004; Köthe, 2005; Louwye et al., 2007a; Donders et al., 2009) as in the Salisbury Embayment, and it is close to the top of zone DN9 and dated at c. 7.6 Ma in Denmark (Dybkjær and Piasecki, 2010). The early disappearance of this species in northern Italy (lower part of Subchron C4An, Mazzapiedi section, c. 9.0 Ma; Zevenboom, 1995) contrasts sharply with the North Sea records.

Pliocene records of this species for central North Atlantic DSDP Sites 607 and 611 (Mudie, 1987) have been acknowledged as representing misidentifications (see Head et al., 1989c for details), and a record from the Pliocene of DSDP Site 408 on the Reykjanes Ridge (Engel, 1992) was attributed to reworking by de Verteuil and Norris (1996).

\section{HO Operculodinium piaseckii (Plate I, 6-7)}

Occurrence: Sample 907A-12H-2, 68-70 cm; 104.5 mbsf.

Magnetostratigraphic calibration: Interpolation between top $\mathrm{C} 5 \mathrm{n} .2 \mathrm{n}$ and top C3Ar.

Age assessment: $8.4 \mathrm{Ma}$ (late Tortonian).

Discussion: This species was first described by Strauss and Lund (1992) but had been reported previously from across the North Atlantic and adjacent seas as Operculodinium sp. of Piasecki (1980).

In the Salisbury Embayment, eastern U.S.A. the HO is within DN9, this zone being approximately coincident with Chron C4 (c. 8.8-7.5 Ma) in the western North Atlantic (de Verteuil and 
Norris, 1996). In ODP Hole 905A off New Jersey, the HO of O. piaseckii is at the top of zone DN9 (upper Tortonian, de Verteuil, 1996; Gartner and Shyu, 1996).

In Labrador Sea ODP Hole 646B, the HO is at c. 8.6-8.3 Ma within the uppermost part of nannofossil zone NN10 (Head et al., 1989c; Knüttel et al., 1989). From offshore West Greenland, this species has an HO within the Tortonian (Piasecki, 2003), and in Norwegian Sea ODP Hole 643A, it has a magnetostratigraphically calibrated $\mathrm{HO}$ at c. 7.6 Ma (Subchron C4n.1n; Manum et al., 1989; Mudie, 1989; Bleil, 1989).

In eastern North Atlantic DSDP Hole 555, the $\mathrm{HO}$ is recorded within the lower part of calcareous nannofossil zone NN11 (upper Tortonian, Edwards, 1984; Backman, 1984). A single isolated lower Zanclean record from eastern North Atlantic DSDP Hole 553A (Edwards, 1984; Backman, 1984) is considered reworked.

For the Danish sector of the eastern North Sea Basin, Dybkjær and Piasecki (2010) reported an HO within their Hystrichosphaeropsis obscura zone (c. 8.8-7.6 Ma); and in the Gram boring in Denmark, where this species was first described (as Operculodinium sp. in Piasecki, 1980), it ranges to the top of the Gram Formation which is dated as Tortonian (Piasecki, 1980, 2005). An unusually high occurrence was reported from the uppermost Tortonian-Messinian (c. 7.5-5.7 Ma) Kasterlee Formation of Belgium by Louwye et al. (2007a). However, in the Nieder Ochtenhausen borehole, northern Germany, its HO coincides with that of H. obscura (Strauss et al., 2001) and is therefore assignable to zone DN9 (Köthe and Piesker, 2007).

For the Mazzapiedi section of northwestern Italy, Zevenboom (1995) recorded an $\mathrm{HO}$ at the top of the section, dated at c. 8.5 Ma within the lower part of Subchron $\mathrm{C} 4 \mathrm{r}$ and within calcareous nannofossil zone NN11a.

Sporadic higher records include an isolated Upper Pliocene occurrence in the Gulf of Mexico (Wrenn and Kokinos, 1986) and rare occurrences in the uppermost Miocene or Lower Pliocene of DSDP Hole 408 in the Irminger Sea (Engel, 1992; Poore, 1979) that are likely all reworked.

HO Batiacasphaera hirsuta (Plate III, 1-3)

Occurrence: Sample 907A-12H-2, 68-70 cm; 104.5 mbsf.

Magnetostratigraphic calibration: Interpolation between top $\mathrm{C} 5 \mathrm{n} .2 \mathrm{n}$ and top C3Ar.

Age assessment: $8.4 \mathrm{Ma}$ (late Tortonian).

Discussion: The HO obtained at Site 907 is tentative owing to the sporadic occurrence of this species in the upper part of its range. However, this position is consistent with that in Norwegian Sea ODP Hole 643A (Subchron C4r.2r, c. 8.4 Ma, Manum et al., 1989; Bleil, 1989). In Norwegian Sea ODP Hole 642C (Manum et al., 1989), the HO is within the Messinian (Goll, 1989) but based on a sporadic record. The HPO is within a possible hiatus (Bleil, 1989), thus hindering a reliable age determination. Poulsen et al. (1996) recorded a single, rare occurrence in the Lower Pliocene of Hole 907A (Section 9H-4 at 78.55 mbsf, c. 5.0 Ma based on our time scale), which we attribute to reworking.

In Iceland, this species occurs fairly persistently in low numbers in the Tjörnes beds which are dated as Zanclean, and it has an HO in the Lower Pleistocene Hörgi Formation (Verhoeven et al., 2011). We consider these Lower Pleistocene specimens reworked, possibly from local Miocene deposits, as this formation is characterized by alternating glacial diamictites and interglacial marine deposits, and frequent occurrences of reworked clasts. In the Tjörnes beds, Batiacasphaera hirsuta occurs rarely but fairly persistently in the lower Serripes zone and upper Mactra zone, but is nearly absent from the underlying Tapes zone. The two youngest units represent the deepest depositional environment, and hence an interval of increased subsidence (Verhoeven et al., 2011), which might have introduced reworked specimens from older Miocene strata, explaining the unusually high stratigraphic occurrence of this species.
For northern Germany, Köthe and Piesker (2007) reported an HO within their zone DN8 (lower to mid-Tortonian; Köthe, 2005). Munsterman and Brinkhuis (2004) noted the presence of Batiacasphaera hirsuta in their Southern North Sea Miocene zones 6 and 9 (c. 15-12 Ma), but in many Dutch wells it ranges into zone 14 (c. 7.4-8.1 Ma; D. Munsterman, pers. commun., 2012). Louwye et al. (2000) reported this species from the Antwerp Sands in Belgium but this study is restricted to the Middle Miocene and an $\mathrm{HO}$ was not recognized.

Zevenboom (1995) recorded an HO at the top of the Mazzapiedi section of northwestern Italy, dated at c. 8.5 Ma within the lower part of Subchron C4r and within calcareous nannofossil zone NN11a.

HCO Cristadinium cristatoserratum (Plate IV, 10-12) Occurrence: Sample 907A-12H-1, 127-129 cm; 103.6 mbsf. Magnetostratigraphic calibration: Interpolation between top C5n.2n and top C3Ar.

Age assessment: 8.3 Ma (mid-Tortonian).

Discussion: The HO observed from our data (5.5 Ma) is consistent with its $\mathrm{HO}$ in western North Atlantic DSDP Hole $603 \mathrm{C}$ at c. $5.7 \mathrm{Ma}$ where it is restricted to the lowest two samples of the analyzed section (M.J.H, unpubl. data; Canninga et al., 1987). However, we acknowledge that the $\mathrm{HO}$ is defined by sporadic occurrences in Hole 907A. In Hole 907A, the HCO of this species at $8.3 \mathrm{Ma}$ is considered the more reliable datum, although we recognize that it coincides with the onset of (locally?) unfavorable conditions at Site 907 as indicated by the deposition of ice-rafted debris (Fronval and Jansen, 1996).

In Labrador Sea ODP Hole 646B, the HO (Head et al., 1989a, 1989c) is calibrated at c. $7.4 \mathrm{Ma}$ (top of nannofossil zone NN11a; Knüttel et al., 1989), but inaccuracies in the age model presumably account for some of the observed age differences with other sites. De Verteuil (1996) reported C. cristatoserratum from offshore New Jersey ODP Hole 903C in the lower and mid-Tortonian zone DN8 of de Verteuil and Norris (1996). However, he recorded it in the uppermost sample of his analyzed interval, preventing the complete stratigraphic range from being determined. This species occurs also in the Miocene of Baffin Bay ODP Hole 645E where it was recorded by Head et al. (1989b) in the highest sample analyzed, and dated as Late Miocene, although independent age control is poor for this interval of Hole $645 \mathrm{E}$.

\section{Messinian (Late Miocene)}

HCO Decahedrella martinheadii (Plate IV, 18-19)

Occurrence: Sample 907A-11H-1, 73-75 cm; 93.5 mbsf.

Magnetostratigraphic calibration: Top of Subchron C3An.2n (interpolation between top of Subchron $\mathrm{C} 3 \mathrm{Ar}$ and top of Subchron C3An.2n).

Age assessment: $6.5 \mathrm{Ma}$ (mid-Messinian).

Discussion: The stratigraphic ranges of this acritarch species and their implications for North Atlantic biostratigraphy were discussed in detail by Matthiessen et al. (2009b), who determined an HO at c. 6.2 Ma based on Norwegian Sea ODP Holes 642B/C and 985A and Iceland Sea Hole 907A. Our new studies from Hole 907A broadly confirm this datum, but because Poulsen et al. (1996) reported the HO to be slightly higher than ours at 91.36 mbsf (not 91.26 mbsf as erroneously stated by Matthiessen et al., 2009b) we calculate a slightly older age of 6.3 Ma for the HO. However, this datum is marked by few specimens only and might result from reworking. Conversely, the HCO, which is marked by a remarkable acme where this species constitutes up to $90 \%$ of the assemblage (i.e., total dinocysts + Decahedrella martinheadii) in Hole 907A, is an unambiguous event. We therefore use the $\mathrm{HCO}$, rather than the $\mathrm{HO}$, as it is more robustly recognizable. Indeed, Matthiessen et al. (2009b) reported a possibly time equivalent acme from IODP Site M0002A (Arctic Ocean) and ODP Sites 908 
and 909 (Fram Strait) and 985 (southern Norwegian Sea) that may allow the HCO of this species to be recognized between c. 6.7 and 6.3 Ma across the Norwegian-Greenland Sea.

\section{Zanclean (Early Pliocene)}

HCO Batiacasphaera micropapillata (Plate III, 4-10)

Occurrence: Sample 907A-9H-1, 40-42 cm; 74.2 mbsf.

Magnetostratigraphic calibration: Upper part of Chron C3 (interpolation between base and top of Chron C3).

Age assessment: $4.6 \mathrm{Ma}$ (mid-Zanclean).

Discussion: Specimens in Hole 907A have a range of microreticulate, microvermiculate, and microrugulate ornamentation. Batiacasphaera minuta is exclusively microreticulate (Matsuoka and Head, 1992) but otherwise similar to Batiacasphaera micropapillata, which is described as having a range of micropapillate, finely granulate, to microreticulate ornament (Stover, 1977). A conceptual overlap therefore exists between these species (Matsuoka and Head, 1992). Although micropapillate forms were seen only rarely, we assign our specimens to $B$. micropapillata to encompass the range of ornament observed. Nonetheless, the $\mathrm{HCO}$ and $\mathrm{HO}$ in Hole 907A comprise microreticulate specimens assignable to $B$. minuta. To facilitate comparison with records elsewhere, we follow De Schepper and Head (2008) in treating both species together for purposes of stratigraphic synthesis.

This species has an HCO in Hole 907A at 4.6 Ma, with rare, sporadic occurrences extending to its $\mathrm{HO}$ at $3.4 \mathrm{Ma}$ (lower Piacenzian). In Labrador Sea ODP Hole 646B, the HPO and HCO are near the nannofossil zone NN15/NN16 boundary dated at c. $3.7 \mathrm{Ma}$ (as Batiacasphaera sphaerica in de Vernal and Mudie, 1989; Knüttel et al., 1989), with sporadic higher occurrences likely attributable to reworking (De Schepper and Head, 2008). Its HCO is magnetostratigraphically calibrated at c. $4.0 \mathrm{Ma}$ in western North Atlantic DSDP Hole 603C (Subchron C2Ar, M.J.H., unpubl. data; Canninga et al., 1987). See also discussion under HO.

HO Reticulatosphaera actinocoronata (Plate IV, 7-8) Occurrence: Sample 907A-8H-6, 140-142 cm; 73.2 mbsf. Magnetostratigraphic calibration: Upper part of Chron C3 (interpolation between base and top of Chron C3).

Age assessment: $4.5 \mathrm{Ma}$ (mid-Zanclean).

Discussion: The HO derived from our data agrees well with findings from Greenland Sea ODP Hole 987E (Subchron C3n.3n, c. $4.8 \mathrm{Ma}$, Channell et al., 1999b), Norwegian Sea ODP Hole 642C (c. $4.2 \mathrm{Ma}$; Mudie, 1989; Bleil, 1989), Labrador Sea ODP Hole 646B (lower part of nannofossil zone NN15, older than $3.9 \mathrm{Ma}$ within the mid- to upper Zanclean, as Impletosphaeridium sp. in de Vernal and Mudie, 1989; Knüttel et al., 1989), central North Atlantic DSDP Site 607 (Subchron C3n.4n, c. 5.0 Ma; as ?Cannosphaeropsis sp. 1 in Mudie, 1987; Clement and Robinson, 1987; although this record is based on sporadic occurrences), and central North Atlantic DSDP Site 611 (Subchron C3n.1r, c. 4.4 Ma, Mudie, 1987; Clement and Robinson, 1987). In western North Atlantic DSDP Hole 603C, this species has an $\mathrm{HCO}$ at c. $4.5 \mathrm{Ma}$ and an $\mathrm{HO}$ at c. $4.0 \mathrm{Ma}$ (M.J.H., unpubl. data; Canninga et al., 1987). It is uncertain whether specimens above the $\mathrm{HCO}$ are reworked. Judging from the above records, an HO recorded within the Matuyama Chron in Fram Strait ODP Hole 986D (Smelror, 1999; Channell et al., 1999b) must represent reworking. In the Tjörnes beds of Iceland, the $\mathrm{HO}$ is recorded in the mid-Zanclean (Verhoeven et al., 2011). In Belgium, this species has not been reported higher than the Kattendijk Formation (c. 5.0-4.4 Ma, Louwye et al., 2004; De Schepper et al., 2008), which is overlain unconformably by the Luchtbal Sands (c. 3.7-3.2 Ma; De Schepper et al., 2008). However, this record provides only limited independent age control because the Kattendijk Formation is constrained partly by the North Atlantic HO of $R$. actinocoronata at 4.4 Ma.
HO Operculodinium? eirikianum (Plate I, 4-5)

Occurrence: Sample 907A-8H-6, 140-142 cm; 73.2 mbsf.

Magnetostratigraphic calibration: Upper part of Chron C3 (interpolation between base and top of Chron C3).

Age assessment: $4.5 \mathrm{Ma}$ (mid-Zanclean).

Discussion: In western North Atlantic DSDP Hole 603C, the HPO is recorded near the base of Subchron C2An.3n at c. 3.6 Ma, and it is uncertain whether rare and sporadic occurrences as high as the Olduvai Subchron at c. $1.8 \mathrm{Ma}$ are reworked (M.J.H., unpubl. data; Canninga et al., 1987). In Labrador Sea ODP Hole 646B, the HO is recorded in the middle of calcareous nannofossil zone NN16 (mid-Piacenzian, as Operculodinium longispinigerum in de Vernal and Mudie, 1989; Knüttel et al., 1989). Off West Greenland, it was reported from the Upper Miocene but not from the unconformably overlying Zanclean (Piasecki, 2003).

In Norwegian Sea ODP Hole 642C, it was recorded in the highest sample investigated (as Operculodinium longispinigerum in Mudie, 1989), which was dated at c. 3.4 Ma (Subchron C2An.3n, Bleil, 1989), but in Hole 642B its HO seems to occur within the Olduvai Subchron at c. 1.8 Ma (as O. longispinigerum unillustrated in Mudie, 1989; Bleil, 1989), and in Norwegian Sea ODP Hole 644A it apparently has an HO at the top of the Gauss Chron at c. 2.6 Ma (Mudie, 1989; Bleil, 1989). Taxonomic uncertainties relating to this species in the Norwegian Sea are discussed by Mudie (in Head and Wrenn, 1992) and Head $(1993,1996)$.

In eastern North Atlantic DSDP Hole 610A, the $\mathrm{HO}$ is magnetostratigraphically-calibrated to c. $2.6 \mathrm{Ma}$ (top C2An.1n, De Schepper and Head, 2008; Clement and Robinson, 1987), and this species ranges to at least MIS 91 (2.34 Ma) in central North Atlantic DSDP Hole 607/607A (Versteegh, 1997). A single, but apparently in-situ, specimen was reported from the warm-water St. Erth Beds of southwestern England, which are dated at c. $2.0 \mathrm{Ma}$ (Head, 1993, 1999).

In the southern North Sea Basin, an HO is recorded at c. 2.4 Ma (Gelasian) both in eastern England (Head, 1996, 1998a, 1998b) and the offshore northern Netherlands sector of the southern North Sea (Kuhlmann et al., 2006a, 2006b).

\section{HO Pyxidinopsis vesiculata (Plate I, 16-18)}

Occurrence: Sample 907A-8H-6, 140-142 cm; 73.2 mbsf.

Magnetostratigraphic calibration: Upper part of Chron C3 (interpolation between base and top of Chron C3).

Age assessment: $4.5 \mathrm{Ma}$ (mid-Zanclean).

Discussion: This species has been reported previously only from western North Atlantic DSDP Hole 603C where it has an HO in Subchron C3n.2n at c. $4.5 \mathrm{Ma}$ (Head and Norris, 2003; Canninga et al., 1987), and eastern North Atlantic DSDP Hole 610A where its HO is at c. 3.9 Ma (Subchron C2Ar, De Schepper and Head, 2008; Clement and Robinson, 1987). The re-examination of a specimen from the Upper Miocene (nannofossil zone NN11b, Knüttel et al., 1989) of Labrador Sea ODP Hole 646B illustrated as Batiacasphaera/Cerebrocysta? Group A by Head et al. (1989c, pl. 1, fig. 4) confirms that it is Pyxidinopsis vesiculata (M.J.H., unpubl. data).

\section{HO Corrudinium devernaliae (Plate I, 11-12)}

Occurrence: Sample 907A-8H-6, 140-142 cm; 73.2 mbsf.

Magnetostratigraphic calibration: Upper part of Chron C3 (interpolation between base and top of Chron C3).

Age assessment: $4.5 \mathrm{Ma}$ (mid-Zanclean).

Discussion: This species is present in a single sample where it is common. Such an isolated occurrence clearly restricts the reliability of this event as an $\mathrm{HO}$ at Hole 907A (Fig. 3), but it falls within the narrow range recorded for this species from other sites. In western North Atlantic DSDP Hole 603C, it has a magnetostratigraphically-calibrated range of 4.7-4.1 Ma within the mid-Zanclean (Head and Norris, 2003; Canninga et al., 1987). In Labrador Sea ODP Hole 646B, this species also has a narrow range, with an LO in nannofossil zone NN12 and an HPO calibrated to the nannofossil zone NN15/16 boundary dated at 
c. 3.7 Ma (as Corrudinium sp. 1 in de Vernal and Mudie, 1989; Knüttel et al., 1989). Sporadic higher occurrences in Hole 646B probably represent reworking (Head and Norris, 2003). In eastern North Atlantic DSDP Hole $610 \mathrm{~A}$, the $\mathrm{HO}$ is magnetostratigraphically calibrated to c. $3.9 \mathrm{Ma}$ (Subchron C2Ar, De Schepper and Head, 2008; Clement and Robinson, 1987). In the southern North Sea basin, within Belgium this species is restricted to the Kattendijk Formation (c. 5.0-4.4 Ma, Louwye et al., 2004; De Schepper et al., 2008), which is unconformably overlain by the Luchtbal Sands (c. 3.7-3.2 Ma, De Schepper et al., 2008).

HO Operculodinium tegillatum (Plate I, 8-10)

Occurrence: Sample 907A-8H-6, 140-142 cm; 73.2 mbsf.

Magnetostratigraphic calibration: Upper part of Chron C3 (interpolation between base and top of Chron C3).

Age assessment: $4.5 \mathrm{Ma}$ (mid-Zanclean).

Discussion: In western North Atlantic DSDP Hole 603C, the HCO is magnetostratigraphically-calibrated at c. $4.0 \mathrm{Ma}$, but this species extends continuously to its $\mathrm{HO}$ at c. $3.6 \mathrm{Ma}$ (M.J.H., unpubl. data; Canninga et al., 1987). In Labrador Sea ODP Hole 646B, the HPO is recorded at c. 3.6 Ma close to the nannofossil zone NN15/16 boundary (as Operculodinium crassum in de Vernal and Mudie, 1989; Knüttel et al., 1989) with sporadic higher occurrences likely representing reworking. In eastern North Atlantic DSDP Hole 610A, the HO has a magnetostratigraphically-calibrated age of c. 3.7 Ma (Subchron C2Ar, De Schepper and Head, 2008; Clement and Robinson, 1987). In the Tjörnes beds of Iceland, the $\mathrm{HO}$ is within the mid-Zanclean (Verhoeven et al., 2011).

In eastern England, this species occurs within the Coralline Crag Formation (Head, 1997), which is dated biostratigraphically as mid- to late Zanclean (Head, 1998a; De Schepper et al., 2008), but is absent from the unconformably overlying Walton Crag Formation dated c. 2.7 Ma (Head, 1998b). In Belgium, this species has been recorded abundantly throughout the Kattendijk Formation, which is dated biostratigraphically at c. 5.0-4.4 Ma (Louwye et al., 2004; De Schepper et al., 2008), but only as reworked specimens from the unconformably overlying Luchtbal Sands (c. 3.7-3.2 Ma, De Schepper et al., 2008).

\section{Piacenzian (Late Pliocene)}

HO Batiacasphaera micropapillata (Plate III, 4-10)

Occurrence: Sample 907A-7H-7, 41-43 cm; 64.2 mbsf.

Magnetostratigraphic calibration: Lower part of Subchron C2An (interpolation between top of Subchron C2Ar and top of Subchron C2An.2r). Age assessment: $3.4 \mathrm{Ma}$ (early Piacenzian).

Discussion: Taxonomic aspects are discussed under the HCO. Although we calibrate the $\mathrm{HO}$ at 3.4 Ma in Hole 907A, we acknowledge that this datum is defined by sporadic occurrences only and therefore tentative. In Labrador Sea ODP Hole 646B, the $\mathrm{HPO} / \mathrm{HCO}$ is close to the calcareous nannofossil NN15/16 boundary at c. 3.7 Ma (as Batiacasphaera sphaerica in de Vernal and Mudie, 1989; Knüttel et al., 1989), and sporadic occurrences above that level have been attributed to reworking (De Schepper and Head, 2008). Its HO is magnetostratigraphicallycalibrated at c. 3.8 Ma in eastern North Atlantic DSDP Hole 610A (Subchron C2Ar, De Schepper and Head, 2008; Clement and Robinson, 1987 ) and at c. 3.7 Ma in western North Atlantic DSDP Hole 603C (Subchron C2Ar, M.J.H., unpubl. data; Canninga et al., 1987). In the Tjörnes beds of Iceland, the $\mathrm{HO}$ is within the mid- to late Zanclean (Verhoeven et al., 2011).

Within the discontinuous Pliocene record of eastern England, this species has a highest occurrence in the Ramsholt Member of the Coralline Crag Formation (Head, 1997), which is biostratigraphicallydated at c. 4.4-3.8 Ma (De Schepper et al., 2008) but unconformably overlain by the Walton Crag Formation which dates to c. $2.7 \mathrm{Ma}$ (Head, 1998b). In Belgium, this species has not been reported higher than the Kattendijk Formation (c. 5.0-4.4 Ma, Louwye et al., 2004; De
Schepper et al., 2008), except for sporadic higher occurrences in the unconformably overlying Luchtbal Sands (c. 3.7-3.2 Ma) that are attributed to reworking (De Schepper et al., 2008).

\section{Discussion}

The appearance and disappearance datums of dinocyst species are rarely precisely synchronous worldwide (e.g. Williams et al., 2004), especially in the late Cenozoic owing to increasing latitudinal temperature gradients. Nonetheless, De Schepper and Head (2008) recently compared mid-Pliocene through Pleistocene dinocyst events across the North Atlantic and, despite evident latitudinal control on the stratigraphic ranges of many species, they identified several bioevents suitable for supraregional stratigraphic correlation.

Of the 26 bioevents defined in Hole 907A, 21 are HOs or HCOs, clearly reflecting a diminishing diversity of Miocene taxa in response to the deterioration of climate towards and into the Pliocene. Fig. 5 shows those dinocyst and acritarch bioevents in Hole 907A that have potential to extend North Atlantic biostratigraphy into the higher latitudes.

\subsection{Supraregional biostratigraphic correlation}

For Hystrichosphaeropsis obscura (Plate II, 1-5), comprehensive literature reviews of the North Atlantic region show most HOs in the Middle and Upper Miocene (Head et al., 1989c; Warny and Wrenn, 2002; Louwye et al., 2007a). Indeed, H. obscura has an HO at c. 7.6 Ma in the Norwegian Sea, within the lower part of nannofossil zone NN11 in the eastern North Atlantic, and at c. 7.5 Ma in the western North Atlantic, all within the upper Tortonian; and most HOs in the North Sea basin are within the upper Tortonian, although there is little independent control on these records. In Iceland Sea ODP Hole 987E, it seems to disappear contemporaneously at c. 7.2 Ma although no quantitative data are available to judge whether this datum, which is close to the base of the core, is based on a persistent or sporadic occurrence. If the $\mathrm{HO}$ in Hole 987E is reliable, then the full stratigraphic range in Hole 907A may not have been detected. In Hole 907A, $H$. obscura has a scarce and somewhat sporadic occurrence through the Serravallian and lower Tortonian up to 10.6 Ma where it is relatively common in one sample (the HCO). Three higher isolated occurrences up to 8.8 Ma may be in place or reworked, although the latter is more likely because this species has an affinity for warm-temperate waters, judging from its stratigraphic distribution elsewhere (see also Head et al., 1989b) - and the lowest evidence of dropstones at 116.5 mbsf (Shipboard Scientific Party, 1995) just above the $\mathrm{HCO}$ at $123 \mathrm{mbsf}$ indicates cooling that presumably led to ecological exclusion above this HCO in Hole 907A. Therefore, while our comparison suggests a high correlation potential for the $\mathrm{HO}$ of H. obscura across much of the North Atlantic region, the cold-water domain of Site 907 must be excluded.

Labyrinthodinium truncatum (Plate IV, 3-6) has an unusually high (c. 7.2 Ma, lowermost Messinian) and thus questionable record in Iceland Sea ODP Hole 987E, but a comparable HO of 8.4 Ma in Hole 907A and c. 8.6-7.6 Ma (late Tortonian) in the Norwegian Sea, which suggests potential for correlation within the Nordic Seas. Moreover, it does not range higher than calcareous nannofossil zone NN10 (mid-Tortonian) in the Labrador Sea and the eastern North Atlantic, which seems to permit supraregional correlations between these high latitude sites. In contrast, from the mid-latitude sites of the Salisbury Embayment, offshore New Jersey, and in the North Sea Basin, this event is consistently recorded in the uppermost Tortonian at c. $7.5 \mathrm{Ma}$. While latitudinal control on the disappearance of L. truncatum might have contributed to this discrepancy, these mid-latitude sites represent shallow-water environments and have less reliable age control. Moreover, dinocyst datums are used in dating the North Sea Basin, possibly introducing bias through circular reasoning (see Section 3.1). Head et al. (1989c) reviewed the 


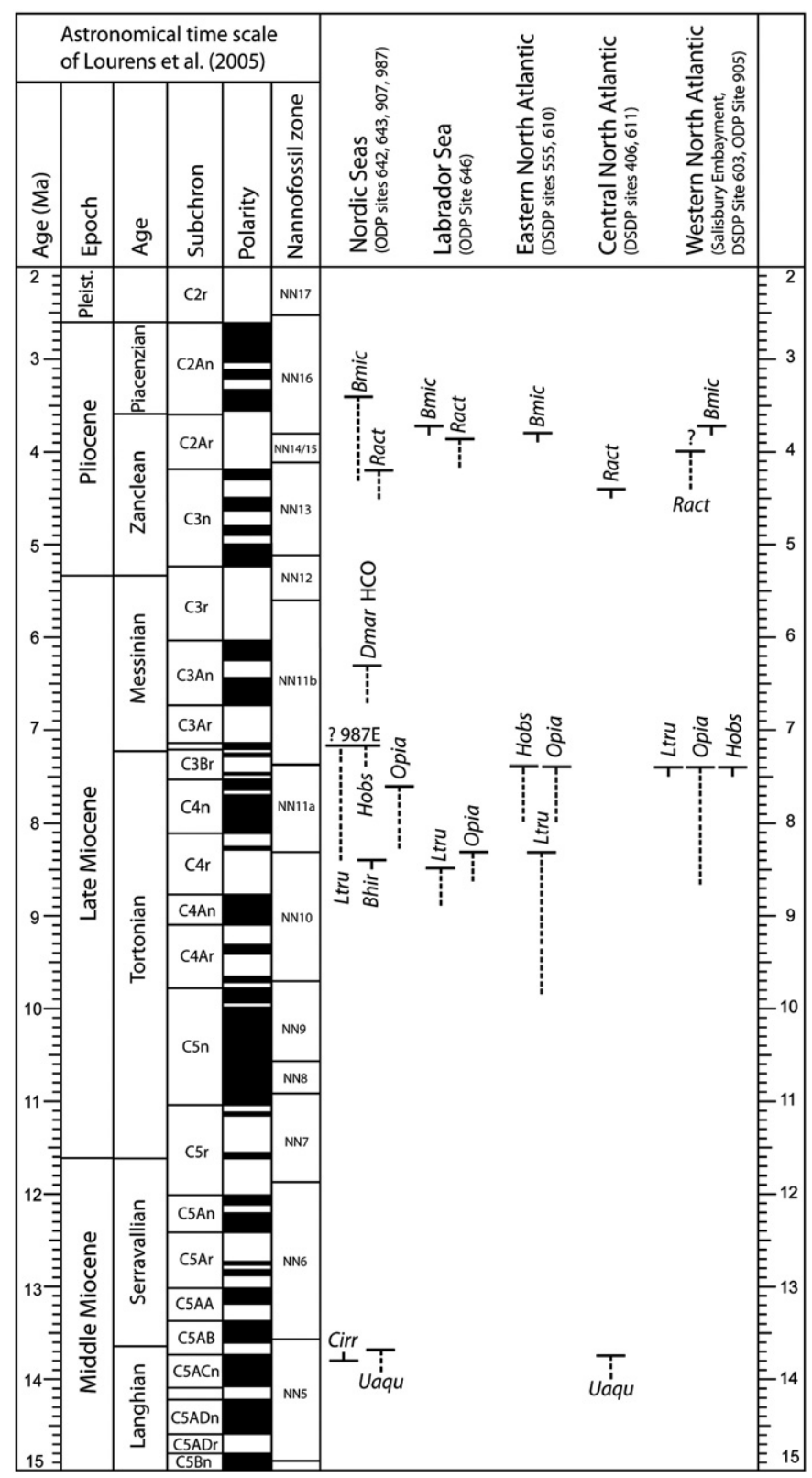

Fig. 5. Correlation of key dinoflagellate cyst and acritarch bioevents across the North Atlantic region and the North Sea basin. Vertical dashed lines indicate the range of uncertainty in the position of a bioevent at the various sites (see Section 3.2), and question marks indicate uncertainty in the assessment of a bioevent (for discussion see Section 4). Data are from Manum et al. (1989), Mudie (1989), Channell et al (1999b), and this study for the Nordic Seas; Head et al. (1989c), de Vernal and Mudie (1989) for the Labrador Sea; Edwards (1984) and De Schepper and Head (2008) for the eastern North Atlantic; Costa and Downie (1979) and Mudie (1987) for the central North Atlantic; and de Verteuil (1996), de Verteuil and Norris (1996), and $\mathrm{MJH}$ (unpubl. data) for the western North Atlantic. Species codes are given in Table 1.

stratigraphic literature on L. truncatum and concluded that its $\mathrm{HO}$ was in the lower Upper Miocene, which is validated by this study with no confirmed record above the uppermost Tortonian. Despite its offset between the mid- and high latitudes, $L$. truncatum appears to be a potentially useful stratigraphic marker for the mid- to upper Tortonian and for approximate correlations between both regions.

Reticulatosphaera actinocoronata (Plate IV, 7, 8) disappeared within a relatively short interval between c. 5.0 and $4.0 \mathrm{Ma}$ in the Zanclean within the entire North Atlantic region, and if inaccuracies in age control and low sample resolution and the likelihood of reworking are all taken into consideration then this interval narrows to around c. 4.8-4.2 Ma in the mid-Zanclean. This species had a cosmopolitan distribution in the Miocene and apparently disappeared in other oceans within the Zanclean (Matsuoka et al., 1987; Williams et al., 2004; Udeze and Oboh-Ikuenobe, 2005) suggesting a global stratigraphic potential. This may include the marginal Arctic Ocean since it has been observed in Miocene sediments of the Beaufort Sea (Bujak and Davis, 1981).

Batiacasphaera micropapillata (Plate III, 4-10) exhibits a narrow range of HOs throughout the North Atlantic between c. 3.8 and 3.4 Ma, which suggests good correlation potential across the various North Atlantic basins in the late Zanclean and earliest Piacenzian. An approximately similar stratigraphic range in the North Sea, with no confirmed records above the Zanclean, may allow correlation between the North Atlantic and the North Sea. However, a comparison of HOs across the North Atlantic reveals a "reversed" succession of lower HOs at the southern sites (c. 3.8-3.7 Ma) and higher ones at the northern sites (c. 3.7-3.4 Ma), which is difficult to explain with a normal latitudinal gradient during the Neogene. However, as we cannot disregard the possibilities of reworking and inaccuracies in age control, the interpretation of this pattern remains enigmatic but may be related to changes in warm water advection via the North Atlantic current (e.g. Lawrence et al., 2009; Naafs et al., 2010). The presence of Batiacasphaera micropapillata in the Middle and Upper Miocene of the central Arctic Ocean (J.M and M.S, unpubl. data) suggests its potential for correlation at very high northern latitudes.

\subsection{Regional biostratigraphic correlation}

Unipontidinium aquaeductus (Plate I, 13-15) disappeared somewhat consistently during the late Langhian in the Iceland and Norwegian seas, which allows stratigraphic correlation within the Nordic Seas. In the central North Atlantic, it disappeared near the Langhian/ Serravallian boundary suggesting that this correlation might be extended across this region, but more reliable records are needed. However, at these sites the HO is considerably lower than the well-constrained HPO and $\mathrm{HO}$ of c. $13.1 \mathrm{Ma}$ and c. $12.0 \mathrm{Ma}$ in northern Italy and $\mathrm{HO}$ of c. 12.3 Ma in eastern North Atlantic IODP Site U1318, and also lower than HOs in the mid-latitude western North Atlantic and Europe. This earlier disappearance from the northernmost sites is likely explained by a temperature threshold crossed during the cooling that occurred during the Middle Miocene climate transition (e.g. Flower and Kennett, 1994; Abels et al., 2005). It is nonetheless evident that $U$. aquaeductus does not range higher than calcareous nannofossil zone NN6 in the North Atlantic and adjacent seas.

The HO of the genus Palaeocystodinium (Plate IV, 13-15) is asynchronous across the various North Atlantic basins, ranging from lower Serravallian to upper Tortonian. In contrast, in the North Sea and Mediterranean basins a near-synchronous $\mathrm{HO}$ has been recognized in the mid-Tortonian between c. 9.0 and $8.7 \mathrm{Ma}$ and suggests a similar timing of paleoenvironmental changes. In general, the $\mathrm{HO}$ of Palaeocystodinium spp. is recorded between the middle and upper Tortonian at both midand high northern latitudes, which agrees with its 8.9 Ma age in Hole 907A. This genus apparently does not range higher than the upper Tortonian across the North Atlantic region, which may be useful in high latitude regions where other biostratigraphic information is sparse.

Batiacasphaera hirsuta (Plate III, 1-3) appears to have disappeared contemporaneously at c. $8.4 \mathrm{Ma}$ in the Iceland and Norwegian seas allowing for potential biostratigraphic correlations within the Nordic Seas. Batiacasphaera hirsuta occurs at least as high as c. $8.5 \mathrm{Ma}$ in the Mediterranean Sea and had a wide distribution within the North Sea, where some evidence suggests a similar age for this bioevent. This indicates potential for supraregional correlations but more reliable data are needed on its HO in the North Sea.

The cold-water acritarch Decahedrella martinheadii (Plate IV, 18, 19) has been reported with a tentative near-synchronous $\mathrm{HO}$ at c. 6.3-6.2 Ma from northern high latitude sites (Matthiessen et al., 
2009b) and appears to be an excellent marker across the subpolar/ polar North Atlantic and Arctic Ocean. However, because the HO in Hole 907A is marked by a few specimens only and therefore strongly dependent on sample resolution, we use the HCO for correlations within the Nordic Seas. An HCO is recognized at 6.5 Ma in Hole 907A, and more generally at c. 6.7-6.3 Ma across the NorwegianGreenland Sea, but further investigations of this event in other high latitude sites are needed to improve its constraints.

\subsection{Potentially useful species for biostratigraphic correlation}

Operculodinium piaseckii (Plate I, 6, 7) had a broad biogeographic distribution across the North Atlantic and adjacent seas, but all well-constrained records considered here show a broadly consistent $\mathrm{HO}$ within the upper Tortonian between c. 8.5 and 7.6 Ma. However, this species is often rare and sporadic in its occurrence, which may compromise its reliability as a biostratigraphic marker (de Verteuil and Norris, 1996). The scatter in positions of the HOs may reflect this deficiency, as will the less accurate age control and low sample spacing of some sites used here. Significantly, the well-dated Mediterranean and Iceland Sea sites yield a synchronous HO. The consistent highest occurrence in the upper Tortonian with no confirmed higher record demonstrates some potential for supraregional biostratigraphic correlations.

The HOs of Operculodinium tegillatum (Plate I, 8-10), P. vesiculata (Plate I, 16-18), and C. devernaliae (Plate I, 11, 12) at $4.5 \mathrm{Ma}$ in Hole 907A are lower than elsewhere and likely related to the oceanographic and climatic changes that occurred in the Iceland Sea towards the intensification of northern hemisphere glaciations (e.g. Fronval and Jansen, 1996; Matthiessen et al., 2009a). However, while the HOs of P. vesiculata and $C$. devernaliae are based on sporadic occurrences in Hole 907A, they agree well with those recorded in the western North Atlantic. Their higher occurrence in eastern North Atlantic DSDP Hole 610A may be due partly to the less accurate age control in that part of Hole $610 \mathrm{~A}$ (De Schepper and Head, 2008) but also suggests different oceanographic/climatic conditions at this site presumably related to changes/variability in the North Atlantic current (Lawrence et al., 2009). Due to sparse records of the extinct $P$. vesiculata and $C$. devernaliae, their paleoecological preferences are not well known although their observed biogeographic distribution pattern suggests an adaptation to more temperate conditions. Operculodinium tegillatum has a continuous record in Hole 907A but shows a similar trend with an earlier disappearance than at the other sites considered here.

Notwithstanding the above, Operculodinium tegillatum, $P$. vesiculata, and $C$. devernaliae appear to have HOs within the mid- to upper Zanclean (between 4.5 and 3.6 Ma) across the North Atlantic, and may therefore be helpful in distinguishing this time interval at high northern latitudes where other stratigraphic age control is restricted. The presence of $C$. devernaliae even if sporadic may be of particular value at these high latitudes, as its range is restricted to the Zanclean in the North Atlantic region.

\subsection{Asynchronous last appearances}

The HO of Cerebrocysta poulsenii (Plate IV, 1, 2) varies widely across the North Atlantic and adjacent seas, ranging from lower Serravallian to mid-Tortonian, although most HOs seem to center within the mid- to upper Serravallian. Cerebrocysta poulsenii is typically a scarce constituent of assemblages and this will have contributed to the uncertainty of its $\mathrm{HO}$, as will have the poor age control of some of the sequences. However, these factors alone do not explain discrepancies in the $\mathrm{HO}$ of $C$. poulsenii, especially the remarkable offset between the cold-water (Hole 907A) and warm-water (ODP Hole $643 \mathrm{~A}$ ) domains of the Norwegian-Greenland Sea. Cerebrocysta poulsenii seems to have been sensitive to the thermal gradient between these domains, restricting its biostratigraphic utility.
Cleistosphaeridium placacanthum (Plate IV, 16, 17) apparently has a diachronous HO in the North Atlantic, the North Sea Basin and the Mediterranean, ranging from c. 13.5 to $8 \mathrm{Ma}$. Because it is typically a common contributor to Miocene assemblages, and therefore particularly prone to reworking, those rare and sporadic specimens occurring higher in its observed range are often considered reworked (de Verteuil and Norris, 1996; Köthe, 2003). Our compilation of HCOs in the North Atlantic and adjacent seas at c. 13.5-13.0 Ma shows consistency but is tentative because this datum could not be recognized, or was not registered, at all sites. The HO of this species is obviously subject to greater uncertainty. Moreover, for the eastern North Sea, Dybkjær and Piasecki (2010) concluded that the highest occurrence of this species is not a distinct event but rather an attenuation over several meters. This species is continuously present but in very low numbers in the upper part of its stratigraphic range in Hole 907A, and its range top appears rather well defined. Cleistosphaeridium placacanthum is a neritic species, and given the high latitude and oceanographic setting of Hole 907A, this species might be near the limit of its ecological range, although reworking cannot be excluded. Jiménez-Moreno et al. (2006) discussed the HO of C. placacanthum across the North Atlantic region, and concluded that no reliable records exist above the uppermost Serravallian, as our survey also suggests. If this is correct, then the specimens from Hole 907A may be reworked.

Cordosphaeridium minimum sensu Benedek and Sarjeant (1981) (Plate I, 1-3) has a strongly asynchronous HO across the North Atlantic and marginal seas, ranging from lower Serravallian to upper Tortonian, although several studies record an $\mathrm{HO}$ within the lower to mid-Tortonian, which agrees with its well-defined range top in Hole 907A. Whether higher records may represent natural attenuation or even reworking remains speculative since few quantitative data are available. Uncertainties in age control and sample spacing are insufficient to account for the reported diachrony in the HO of this species, and thus regional changes in surface water masses and variable depositional settings at the different sites must also be considered. This suggests strong ecological control on its stratigraphic range, which, in combination with the taxonomic uncertainties mentioned previously, will have hindered its biostratigraphic utility.

Cerebrocysta irregulare sp. nov. (Plate III, 11-20) is presently known only from this study and tentatively from the Norwegian Sea (questionably synonymized with Tectatodinium sp. 4 in Manum et al., 1989; see Systematic Paleontology). It apparently disappears earlier in Hole 907A than in the Norwegian Sea, and this might be attributable to the thermal gradient between the cold-water-influenced Iceland Sea and the more temperate Norwegian Sea. However, this species has a well-defined stratigraphic range in Hole 907A (Fig. 3) suggesting strong biostratigraphic potential in the cold-water domain of the high northern latitudes.

Impagidinium elongatum sp. nov. (Plate II, 6-20) has an asynchronous $\mathrm{HO}$ in the two well-dated Norwegian and Iceland sea sites, at 8.2 Ma and 10.2 Ma respectively, with a lower HO in the Iceland Sea that likely reflects the influence of the cold East Greenland Current. In Baffin Bay and Belgium, the HO seems broadly similar to that recorded for Hole 907A but is based on poorly dated sequences, and in the case of Baffin Bay the identification is not certain. Regardless, the range top of I. elongatum sp. nov. in Hole 907A is well-defined and may be stratigraphically significant in the polar domain of the Arctic and Subarctic seas.

The asynchronous HO of Dapsilidinium pseudocolligerum (Plate IV, 9) is a clear response to Late Miocene cooling, as this species persisted into the Late Pliocene and Early Pleistocene in the mid- to low-latitude North Atlantic whereas it had already disappeared from high-latitude sites by the middle Late Miocene. This confirms the tropical to warm-temperate affinities of $D$. pseudocolligerum as recognized by Head and Westphal (1999) and is consistent with the observed discrepancy in the Nordic Seas, where it disappeared earlier 
in the colder Iceland Sea (9.1 Ma; mid-Tortonian) than in the more temperate Norwegian Sea (c. 7.6 Ma; late Tortonian). The distribution of this species elsewhere accords with its North Atlantic pattern, as it occurs persistently in the Pliocene of the eastern Indian Ocean (McMinn, 1992) and has an HO in the Upper Pliocene of the northeast Australian margin (McMinn, 1993), but does not range higher than early Middle Miocene in northern Japan (Bujak and Matsuoka, 1986). Although it has a well-defined HO in Hole 907A, the strong climatic control on the distribution of $D$. pseudocolligerum would seem to hinder its biostratigraphic utility even on a regional scale.

Cristadinium cristatoserratum (Plate IV, 10-12) has a fairly synchronous HO in the upper Messinian of the western North Atlantic and Iceland Sea, although sporadic records define this datum at the latter site. The uppermost Tortonian HO in the Labrador Sea is lower than that recorded at other sites, but higher than the mid-Tortonian HCO in Hole 907A. Imprecise age control for Labrador Sea ODP Site 646 might have contributed to the discrepancy. These being the only sites where the upper stratigraphic range of this species is recorded unambiguously, it is likely that this species does not range higher than the uppermost Miocene.

Operculodinium? eirikianum (Plate I, 4, 5) clearly has an asynchronous highest occurrence across the North Atlantic and the North Sea Basin, with a somewhat time-transgressive trend in the succession of HOs. It disappears earlier in the high latitude sites (NorwegianGreenland Sea, Labrador Sea) than in the mid-latitude eastern North Atlantic and North Sea basin, where comparatively warmer waters presumably prevailed longer due to the influence of the North Atlantic current. Head $(1993,1997)$ and De Schepper and Head (2008) regarded 0. ? eirikianum as a mid- to high-latitude cold-intolerant species, which supports the interpretation of an asynchronous last appearance across the North Atlantic in response to differential cooling.

\subsection{First appearances}

The only presently well constrained records for the LO of Cristadinium cristatoserratum (Plate IV, 10-12) are from the Iceland Sea (Langhian) and western North Atlantic (Upper Oligocene). However, the LOs at both sites are based on sporadic occurrences that may not reflect the true stratigraphic range, and all other studies considered here do not record an LO due to inadequate coring depth. This species is evidently adapted to higher-latitude environments and its LO might be climatically controlled, but, until more records become available, it is difficult to assess the stratigraphic potential of this datum.

Although relatively few LOs of Habibacysta tectata (Plate I, 19, 20) have good independent stratigraphic control, most published studies record this datum slightly above the LO of $U$. aquaeductus which is provisionally constrained at 15.1-14.8 Ma (Jiménez-Moreno et al., 2006). Therefore, an LO across the North Atlantic and adjacent seas within calcareous nannofossil zone NN5 (mid- and upper Langhian) appears most likely, which accords with the conclusion of JiménezMoreno et al. (2006). Suspected contamination likely explains a Lower Miocene record from northern Belgium (S. Louwye, pers. commun. in Jiménez-Moreno et al., 2006). Habibacysta tectata seems to have relatively high stratigraphic potential for integrating higher-latitude North Atlantic and North Sea records because of its tolerance of cooler temperatures (Head et al., 1989a; Head, 1994; De Schepper et al., 2011), and its similar LO in IODP Hole M0002A suggests that this may be extended into the central Arctic Ocean.

Cerebrocysta irregulare sp. nov. (Plate III, 11-20) has been recorded only from the Iceland and possibly Norwegian seas (as Tectatodinium sp. 4 in Manum et al., 1989) where it has a near-synchronous LO close to the Langhian/Serravallian boundary. This and its well-defined range in Hole 907A suggest a strong stratigraphic potential for this bioevent in the Nordic Seas.
Operculodinium? eirikianum (Plate I, 4,5 ) has a broad range of LOs ranging from lower Langhian to upper Tortonian, which cannot be explained solely by inaccurate age control and sample resolution. These reported discrepancies may in part reflect confusion with the similar 0.? borgerholtense (see Soliman et al., 2009) and 0.? longispinigerum (see Head and Westphal, 1999), both of which range into the Lower Miocene. Magnetostratigraphically dated records from the Iceland Sea, eastern North Atlantic, and the Mediterranean place the LO of O.? eirikianum between c. 14 and 13 Ma. Indeed, except for the Salisbury Embayment and offshore New Jersey, this species seems to have appeared not later than early Serravallian across the North Atlantic and adjacent seas. However, more well-constrained records are needed to critically evaluate this species' utility for regional and supraregional stratigraphic correlations.

For the first time, the LO of Decahedrella martinheadii (Plate IV, 18, 19) has been magnetostratigraphically-calibrated in the Nordic Seas, to $10.5 \mathrm{Ma}$. At other high latitude sites, with the exception of an LO at c. $11.0 \mathrm{Ma}$ in the Fram Strait, its range base cannot be defined unambiguously due to inadequate coring depth or recovery (Matthiessen et al., 2009b), thus preventing an opportunity to critically evaluate the stratigraphic utility of this event. The first appearance of $D$. martinheadii may have been related to the fundamental reorganization of the surface and deep-water circulation in the northernmost North Atlantic due to the deepening of the Fram Strait (Matthiessen et al., 2009b) and the onset of an East Greenland current precursor (Wolf-Welling et al., 1996).

\subsection{Age assignment for the base of Hole 907A}

Age estimates for the lowermost sediments of Hole 907A based on magnetostratigraphy (Channell et al., 1999a) and ${ }^{40} \mathrm{Ar} /{ }^{39} \mathrm{Ar}$ dating of the underlying tholeiitic basalts (Davis and McIntosh, 1996) do not fully agree (Section 2.2); with extrapolation from magnetostratigraphy giving an age of $14.53 \mathrm{Ma}$ and ${ }^{40} \mathrm{Ar} /{ }^{39} \mathrm{Ar}$ measurements suggesting $13.3 \pm 0.3 \mathrm{Ma}$. Two dinocyst occurrences call into question the ${ }^{40} \mathrm{Ar} /$ ${ }^{39} \mathrm{Ar}$ age. Unipontidinium aquaeductus occurs in the lowermost Sample $23 \mathrm{H}-\mathrm{CC}, 10-12 \mathrm{~cm}$ (216.5 mbsf). The LO of $U$. aquaeductus elsewhere is relatively well constrained, and Jiménez-Moreno et al. (2006) placed this event provisionally at $15.1-14.8 \mathrm{Ma}$ (mid-Langhian). The LO of Habibacysta tectata occurs in Sample 23H-3, 51.5-53.5 cm between the depths of the magnetostratigraphic and ${ }^{40} \mathrm{Ar} /{ }^{39} \mathrm{Ar}$ ages. Elsewhere, it is generally placed slightly higher than the LO of U. aquaeductus in the mid- to upper Langhian calcareous nannofossil zone NN5, with the oldest well-constrained record being dated at no younger than c. 14.8 Ma (Jiménez-Moreno et al., 2006). Because $H$. tectata is a cool-tolerant species, its LO at Hole 907A might be expected to be at least as old as in lower latitudes. Therefore, the basal deposits at Hole 907A are no older than 15.1-14.8 Ma (mid-Langhian) based on the LO of $U$. aquaeductus which is at or slightly predates the basal deposits, and probably no younger than mid- to late Langhian (c. 14.8-13.7 Ma) based on the LO of $H$. tectata which is just above the basal deposits. A mid- to late Langhian age (15.1-13.7 Ma) is accordingly suggested for the basal deposits. This biostratigraphic constraint, while tentative, more closely agrees with the extrapolated magnetostratigraphic age of c. 14.5 Ma than with the radiometric age of $13.2 \mathrm{Ma}$.

As noted by the Shipboard Scientific Party (1995, but adjusting ages to the time scale of Lourens et al., 2005), Site 907 was drilled either on Magnetic Anomaly 6B crust between 22.6 and 21.8 Ma (Talwani and Eldholm, 1977) or Anomaly 5B crust between 16.0 and $14.8 \mathrm{Ma}$ (Vogt et al., 1980), depending on whether sea-floor spreading from the Kolbeinsey Ridge was symmetrical (Vogt et al., 1980) or not (Talwani and Eldholm, 1977). It is not certain whether the basalt at the base of Hole 907A represents oceanic crust or a later submarine eruption (Davis and McIntosh, 1996). If oceanic crust is represented, then both magnetostratigraphy and dinocyst stratigraphy imply that Site 907 sits on Anomaly 5A between 14.8 and $12.0 \mathrm{Ma}$. A younger part of Anomaly 
5B, as proposed by Vogt et al. (1980), would also be possible if the extrapolated magnetostratigraphic age of c. $14.5 \mathrm{Ma}$ is slightly underestimated.

\section{Conclusions}

Based on the palynological analyses of 120 samples spanning the interval c. 14.5-2.5 Ma in ODP Hole 907A at c. $100 \mathrm{kyr}$ temporal resolution, a magnetostratigraphic calibration of 26 potentially useful dinocyst and acritarch bioevents has been conducted for the first time in the Miocene and Pliocene of the high northern latitudes. Most events are last appearances and reflect a progressive extinction of species in response to long-term cooling from the Middle Miocene towards the intensification of Northern Hemisphere glaciation in the Late Pliocene.

The calibrated events have been compared with other sites in the North Atlantic and adjacent basins to evaluate their utility for correlations within the high northern latitudes. Our comparison reveals that seven datums are useful within the Nordic Seas, but only four events are suitable for supraregional correlations beyond. This understandably results from a strong latitudinal control on the stratigraphic range of species, often through the earlier disappearance in the cold-water Iceland Sea than elsewhere.

The HOs of B. micropapillata and $R$. actinocoronata have been shown to represent useful bioevents for improving supraregional biostratigraphic correlations between the Nordic Seas and the various North Atlantic basins, and the $\mathrm{HO}$ of $L$. truncatum for supraregional correlation between the Labrador and Nordic seas. Although the $\mathrm{HO}$ of $\mathrm{H}$. obscura seems useful on a supraregional scale, it is of restricted use in the Iceland Sea as its HO is somewhat contradictory at the two sites located within this region. Additionally, the HOs of $U$. aquaeductus and B. hirsuta, and the HCO of $D$. martinheadii are good stratigraphic markers within the Nordic Seas, and this is possibly also true for the LO of $C$. irregulare sp. nov. Furthermore, our comparison suggests that the HOs of O. piaseckii, $O$. tegillatum, $P$. vesiculata, and $C$. devernaliae are potentially useful stratigraphic markers across the North Atlantic over a broader time span.

Most events are clearly diachronous across the North Atlantic, showing no clear pattern of appearance or disappearance and hence presumably representing local or regional paleoenvironmental conditions. Operculodinium? eirikianum disappeared earlier in the highlatitude sites than in the mid-latitudes presumably in response to progressive Pliocene cooling within the Northern Hemisphere. Overall, however, the evaluated dinocyst datums of ODP Hole 907A provide an improved, magnetostratigraphically-calibrated temporal framework for future analyses of Neogene sequences in the high and mid-northern latitudes. Our records are generated from a site critical for understanding paleoclimatic and paleoceanographic evolution, and at a time when Earth's climate finally changed from a "greenhouse" to an "icehouse" world.

Dinocyst stratigraphy suggests the basal sediments of Hole 907A to be no younger than the LO of Habibacysta tectata (mid- to late Langhian; c. 14.8-13.7 Ma) and no older than the LO of Unipontidinium aquaeductus (mid-Langhian, around 15.1-14.8 Ma). These constraints, while tentative, more closely agree with the extrapolated magnetostratigraphic age of c. 14.5 Ma than with the radiometric age of 13.2 Ma for the underlying basalts. If the underlying basalts represent oceanic crust, which is by no means certain, then Site 907 sits on Magnetic Anomaly 5A, or perhaps a younger part of Anomaly 5B.

\section{Systematic paleontology}

Division DINOFLAGELLATA (Butschli, 1885) Fensome et al., 1993 Subdivision DINOKARYOTA Fensome et al., 1993

Class DINOPHYCEAE Pascher, 1914

Subclass PERIDINIPHYCIDAE Fensome et al., 1993

Order GONYAULACALES Taylor, 1980

Suborder GONYAULACINEAE (Autonym)
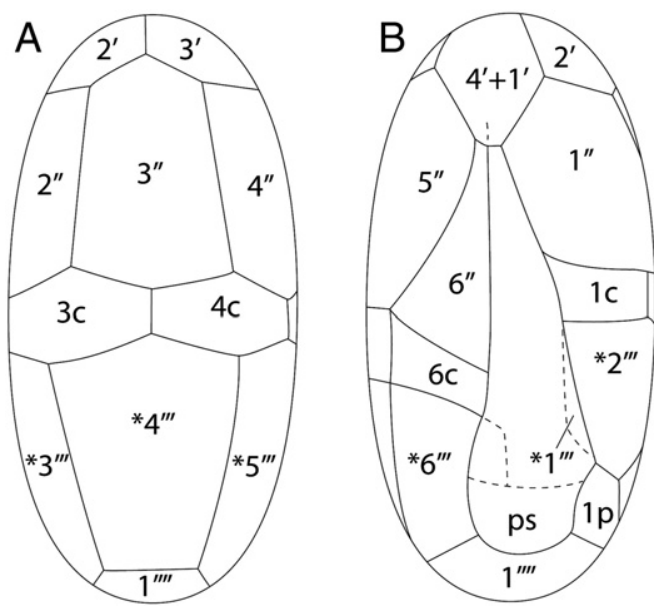

Fig. 6. Generalized tabulation for Impagidinium elongatum sp. nov., using Kofoid labeling with homologues indicated by an asterisk. A dashed line indicates weakly and occasionally expressed plate boundaries. Dorsal (A) and ventral (B) views are shown.

Family GONYAULACACEAE Lindemann, 1928

Subfamily GONYAULACOIDEAE (Autonym)

Genus IMPAGIDINIUM Stover and Evitt, 1978

Type: Impagidinium dispertitum (Cookson and Eisenack, 1965) Stover and Evitt, 1978

Impagidinium elongatum sp. nov. (Plate II, 6-20; Figs. 6, 7)

1989 Impagidinium sp. 3; Manum et al., pl. 12, figs 2-4.

? 1989 Impagidinium sp. 1; Manum et al., pl. 17, figs 7, 8.

? 1992 Impagidinium sp. 1; Anstey, text-fig. 8, pl. 5, fig. 1-3; pl. 18, fig. 1.

? 1992 Impagidinium sp. 2; Anstey, text-fig. 9, pl. 5, fig. 4-6; pl. 18, fig. 2.

2002 Impagidinium sp. 1; Louwye, fig. $5(9,10)$.

Holotype: Sample 907A-13H-6, 20-22 cm; slide 2; England Finder reference P52/2; Plate II, 6-10.

Repository: Invertebrate Section of the Department of Palaeobiology, Royal Ontario Museum, Toronto, Ontario; catalog number ROM 61826. Type locality: ODP Site 907, eastern Iceland Plateau $\left(69^{\circ} 14.989^{\prime} \mathrm{N}\right.$, $\left.12^{\circ} 41.894^{\prime} \mathrm{W}\right)$.

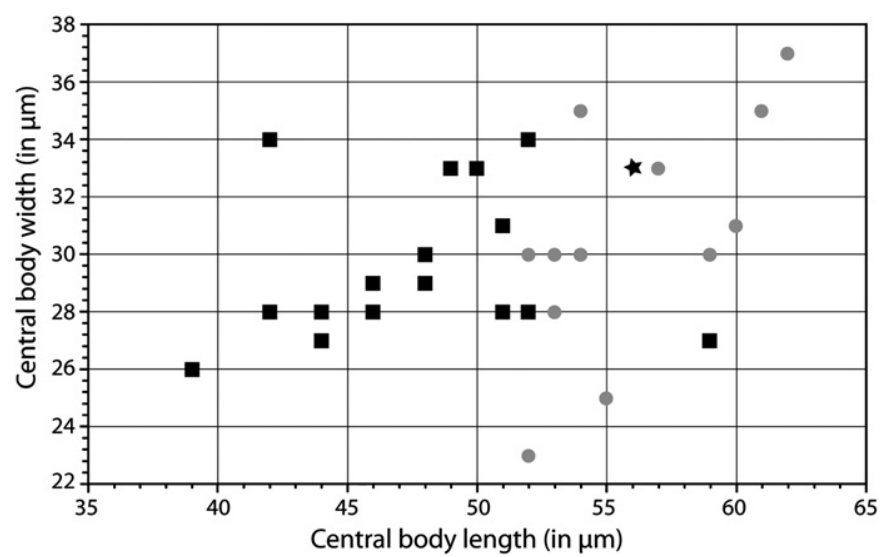

Fig. 7. Central body length vs. central body width for Impagidinium elongatum sp. nov. Black squares $=$ specimens from Samples $907 \mathrm{~A}-21 \mathrm{H}-6,2-4 \mathrm{~cm}$ to $15 \mathrm{H}-2,38-40 \mathrm{~cm}$ (faintly granulate to almost smooth surfaces). Gray circles $=$ specimens from Samples 907A-15H-1, 74-76 cm to $13 \mathrm{H}-2,142-144 \mathrm{~cm}$ (strongly ornamented surfaces). Black star $=$ holotype. 
Stratigraphic horizon: ODP Hole 907A, 119.50 mbsf; lower Tortonian (lower Upper Miocene), Subchron C5n.2n, calibrated age 10.4 Ma. Etymology: Late Latin elongare, elongate, with reference to the characteristic shape of the central body of this species.

Diagnosis: A mid-sized to large species of Impagidinium of variable morphology with strongly elongated central body bearing low crests, some elevated at intersections. The surface is granulate, to granulopunctate, to nearly smooth. Plate 6" is strongly triangular, owing to a steeply descending plate $6 c$, and narrowly contacts plate $1^{\prime}+4^{\prime}$. Sulcal plates are usually weakly and incompletely expressed. Individual cingular plates are usually clearly demarcated, and the cingulum narrows towards boundaries between adjacent cingular plates. The development of sutural crests can be strongly reduced, especially in the equatorial and ventral areas.

Description: Proximate to proximochorate cysts with ovoidal to ovoidal-ellipsoidal central body having a length vs. equatorial diameter usually between 1.5 and 2.3 (a single exception registering 1.2). The central body wall is moderately thick (c. $0.6-1.3 \mu \mathrm{m}$ ) and the outer wall varies from distinctly granulate, to granulo-punctate, to nearly smooth, with thicker-walled specimens usually having more pronounced ornament. A low (up to $2.0 \mu \mathrm{m}$ ) apical protuberance may be present (Plate II, 13). Wall stratification is indistinguishable over most of the central body under LM. Low sutural crests demarcate with variable completeness a gonyaulacacean tabulation with neutral torsion, as for the genus. Crests are developed from the outer layer of the central body wall, and usually arise steeply from the central body surface, the two layers being closely appressed distally and for most or all of the height of the crests. However, slight cavation is occasionally developed at the base of crests, particularly where they intersect. Surface of crests varies from distinctly granulate, to granulo-punctate, to nearly smooth, as for the central body; and crests occasionally have small (up to 2-3 $\mu \mathrm{m}$ ) perforations, or may even be fenestrate (Plate II, 18). Distal margins of crests may be straight, smoothly undulating, to irregular and occasionally serrated, with several types of margin often present on the same cyst. Crests may be mostly of even height, but all specimens have some crests raised at intersections, particularly between adjacent precingular and postcingular plates. Crests may be lower in mid-ventral and mid-dorsal areas. Crests usually demarcate the tabulation quite fully except within the sulcus, where plates are weakly and incompletely expressed by narrow lineations. In the apical area, the boundary between $1^{\prime}$ and $4^{\prime}$ is usually not expressed (Fig. 6), but rarely indicated by a faint and discontinuous line. The precingular and postcingular plates are mostly elongate. Plates 3 " and * 4 "' are both mid-dorsally centered (Fig. 6) indicating neutral torsion. Plate 6 " is strongly triangular, owing to a steeply descending plate $6 c$, and narrowly contacts plate $1^{\prime}+4^{\prime}$. Plate ${ }^{*} 1^{\prime \prime \prime}$ is very narrow and located inside the sulcus, and is seldom expressed (Plate II, 16, 17). The sulcus is only slightly sigmoidal and is bordered by a non-overhanging cingulum, although the strongly triangular 6" conforms to an S-type ventral organization (Fig. 6). The anterior margin of the posterior sulcal plate (ps) is usually expressed by a faint line, and the right sulcal plate may be also. The cingulum is laevorotatory and descends steeply where it approaches the sulcus from the right (plate 6c), resulting in an offset of about two widths. Both upper and lower margins of the cingulum are usually expressed on the ventral surface. Individual cingular plates are usually well demarcated, and the cingulum characteristically narrows towards boundaries between adjacent cingular plates, this being particularly evident on the dorsal surface. The archeopyle is reduced and elongated, and formed by loss of the third precingular plate.

Discussion: While the elongate central body, the tabulation, and low crests that in places slightly rise gonally are stable features, the morphology in general is very variable, and is probably a response to environmental change. In particular, specimens at the top of its range in Hole 907A, in Sample 13H-2, 142-144 cm, have extremely reduced crests in the equatorial region so that almost no tabulation can be discerned in this region (Plate II, 19-20). Samples 21H-6, 2-4 cm, $22 \mathrm{H}-2,147-149 \mathrm{~cm}$, and $22 \mathrm{H}-6,51-53 \mathrm{~cm}$, at the bottom of this species' range, also contain specimens with reduced crests. We interpret this feature as a response to unfavorable conditions, probably reduced salinity judging from other septate species (e.g. the cysts of Gonyaulax baltica; Ellegaard et al., 2002). A specimen illustrated by Manum et al. (1989, pl. 12, figs 2-4, as Impagidinium sp. 3) is intermediate between morphotypes with extremely reduced equatorial tabulation and those with normally expressed tabulation.

A change in the dominant morphotype occurs at around $132 \mathrm{mbsf}$ (11.24 Ma), with specimens in sample $15 \mathrm{H}-1,74-76 \mathrm{~cm}$ and above being on average larger, with thicker central body walls, and with more strongly ornamented surfaces (e.g. Plate II, 6-10). This morphotype ranges down to sample $16 \mathrm{H}-1,17-19 \mathrm{~cm}$. Specimens in sample $15 \mathrm{H}-2,38-40 \mathrm{~cm}$ (e.g. Plate II, 11-16) and below tend to be smaller, with thinner central body walls and faintly granulate to almost smooth surfaces (see Dimensions, and Fig. 7). However, there is intergradation as well as stratigraphic overlap between these morphologies, and we therefore treat them as a single species.

Dimensions: Holotype: central body length, $56 \mu \mathrm{m}$, central body width, $33 \mu \mathrm{m}$, maximum crest height, $4.5 \mu \mathrm{m}$, wall thickness, c. $1.0 \mu \mathrm{m}$. Range for specimens from samples $21 \mathrm{H}-6,2-4 \mathrm{~cm}$ to $15 \mathrm{H}-2$, 38-40 cm: central body length 39(47.7)59 $\mu \mathrm{m}$, central body width $26(29.5) 34 \mu \mathrm{m}$, central body length/width ratio $1.2(1.62) 2.2$, maximum crest height 1.5(4.1)7.0 $\mu \mathrm{m}$, wall thickness c. 0.6(0.8)1.2 $\mu \mathrm{m}$; 18 specimens measured. Range for specimens from samples $15 \mathrm{H}-1$, $74-76 \mathrm{~cm}$ to $13 \mathrm{H}-2,142-144 \mathrm{~cm}$ : central body length $52(56.0)$ $62 \mu \mathrm{m}$, central body width $23(30.9) 37 \mu \mathrm{m}$, central body length/ width ratio $1.5(1.83) 2.3$, maximum crest height 3.8(4.7)5.5 $\mu \mathrm{m}$, wall thickness c. $0.8(1.0) 1.3 \mu \mathrm{m} ; 14$ specimens measured. Overall range: central body length $39(51.3) 62 \mu \mathrm{m}$, central body width 23(30.1) $37 \mu \mathrm{m}$, central body length/width ratio $1.2(1.71) 2.3$, maximum crest height 1.5(4.3)7 $\mu \mathrm{m}$, wall thickness c. 0.6(0.9)1.3 $\mu \mathrm{m}$; 32 specimens measured (see also Fig. 7).

Stratigraphic occurrence: In Hole 907A, Impagidinium elongatum ranges from the Langhian (14.1 Ma) through lower Tortonian (10.2 Ma); with occurrences below 12.6 Ma being sporadic, and an isolated specimen at 9.2 Ma considered reworked.

Elsewhere recorded as Impagidinium sp. 3 in Manum et al. (1989) from the Lower through Upper Miocene of Norwegian Sea ODP Hole 643A (Manum et al., 1989; Bleil, 1989) and Middle Miocene of Norwegian Sea ODP Hole 642C (Manum et al., 1989; Bleil, 1989). Also recorded from the lower Tortonian Deurne Sands of Belgium (as Impagidinium sp. 1 in Louwye, 2002).

Impagidinium sp. 1 of Manum et al. (1989) from the Upper Oligocene through upper Middle Miocene of Norwegian Sea ODP Hole 643A (Manum et al., 1989; Goll in Williams and Manum, 1999) and Lower Miocene of Norwegian Sea ODP Hole 642D (Manum et al., 1989; Bleil, 1989), is questionably synonymized with Impagidinium elongatum. Impagidinium sp. 1 and 2 of Anstey (1992) from the late Middle? to early Late Miocene of Baffin Bay ODP Hole 645E are probably conspecific with I. elongatum.

Suborder uncertain

Genus CEREBROCYSTA Bujak in Bujak et al., 1980

Type: Cerebrocysta bartonensis Bujak in Bujak et al., 1980

Cerebrocysta irregulare sp. nov. (Plate III, 11-20)

? 1989 Tectatodinium sp. 4; Manum et al., pl. 20, figs 6, 7. Holotype: Sample 907A-17H-5, 138-140 cm; slide 1; England Finder reference P43/4; Plate III, 11-14.

Repository: Invertebrate Section of the Department of Palaeobiology, Royal Ontario Museum, Toronto, Ontario; catalog number ROM 61830. 
Type locality: ODP Site 907, eastern Iceland Plateau $\left(69^{\circ} 14.989\right.$ $\left.\mathrm{N}, 12^{\circ} 41.894^{\prime} \mathrm{W}\right)$.

Stratigraphic horizon: ODP Hole 907A, $157.2 \mathrm{mbsf}$; Serravallian (Middle Miocene), Subchron C5Ar, calibrated age 12.9 Ma.

Etymology: Latin irregularis, irregular, with reference to the nature of the muri that characterize this species.

Diagnosis: A species of Cerebrocysta having an almost spherical, ovoidal shape; and surface ornamented with sinuous and discontinuous muri of irregular width (up to c. $1.5 \mu \mathrm{m}$ ) that form a surface pattern varying from microrugulate to an incomplete and irregular microreticulation; with spacing between muri up to c. 2.0 to $3.0 \mu \mathrm{m}$. The archeopyle, formed by loss of plate $3 "$, has well-defined angles.

Description: Proximate cyst with ovoidal shape that is close to spherical, occasionally with a low apical protuberance. Wall ornament consists of sinuous, discontinuous muri that form a surface pattern varying from microrugulate to an incomplete and irregular microreticulation. The muri are of irregular width that varies between c. $1.5 \mu \mathrm{m}$ and $<0.2 \mu \mathrm{m}$, this variation occurring on the same cyst. Muri often widen at intersections. Muri are up to about $1.5 \mu \mathrm{m}$ high; but height varies, with narrower muri often lower than wider muri. Crests are flat-topped (especially at intersections) or taper distally. The lacunae between muri are usually up to about $2.0 \mu \mathrm{m}$ diameter (on the holotype mostly $1.5 \mu \mathrm{m}$ or less; occasionally reaching $3.0 \mu \mathrm{m}$ in other specimens), and vary from rounded polygonal to rectangular. The underlying pedium is about $0.2-0.3 \mu \mathrm{m}$ thick, and both pedium and overlying muri appear solid and continuous under light microscopy. The ornament covers the entire surface of the cyst without variation, and extends to the archeopyle margins without modification. The archeopyle is formed by loss of plate 3", and has well-defined angles. There is no other expression of tabulation.

Discussion: The holotype has a slight $(0.5 \mu \mathrm{m})$ apical protuberance, and one specimen was found to have an unusually pronounced apical protuberance (Plate III, 16), a feature that is absent or very weakly developed in other specimens. Tectatodinium sp. 4 of Manum et al. (1989), from the Miocene of the Norwegian Sea, is questionably synonymized with Cerebrocysta irregulare on account of its similar ornament but more pronounced apical protuberance.

Cerebrocysta irregulare differs from all other validly described species of the genera Cerebrocysta, Corrudinium and Pyxidinopsis by its relatively small size and irregularly-shaped muri that form an incomplete and irregular microreticulate to microrugulate pattern. "Cerebrocysta cassinascoensis" Zevenboom and Santarelli in Zevenboom, 1995 (unpublished manuscript name), from the Langhian through base Serravallian of Italy, is very similar to C. irregulare but differs in having a coarser microreticulation, and apparently larger overall size range of 40-50 $\mu \mathrm{m}$ (Zevenboom and Santarelli in Zevenboom, 1995), although the illustrations of this species somewhat contradict its description. Specimens reported rarely from the upper Langhian of Hungary as "Cerebrocysta cassinascoensis" Zevenboom and Santarelli in Zevenboom, 1995 by Jiménez-Moreno et al. (2006) have slightly coarser ornament than $C$. irregulare but are of similar size (maximum diameter 37-39 $\mu \mathrm{m}$ based on three specimens; M.J.H., unpubl. data). Further research on these Mediterranean-Paratethyan morphotypes is needed to assess their relationship fully with $C$. irregulare.

Dimensions: Holotype: length (including ornament), $39 \mu \mathrm{m}$; wall thickness, c. $1.4 \mu \mathrm{m}$. Range: maximum diameter (including ornament), 32 (38.4) $42 \mu \mathrm{m}$; wall thickness, c. 0.9-1.8 $\mu \mathrm{m}$. Eighteen specimens measured.

Stratigraphic occurrence: In Hole 907A, Cerebrocysta irregulare ranges almost continuously from the uppermost Langhian (13.8 Ma) to lower Tortonian (10.4 Ma).

Tectatodinium sp. 4 of Manum et al. (1989), which we questionably synonymise with Corrudinium irregulare, ranges from the uppermost Langhian through mid-Tortonian in the Norwegian Sea.

\section{Acknowledgments}

This research uses samples and data provided by DSDP and ODP and we thank Walter Hale and Alex Wülbers for technical support while sampling at the IODP Core Repository, Bremen. We are grateful to Morten Smelror who shared unpublished data, and Stijn De Schepper for comments on an earlier draft of this manuscript. Support was provided by the German Research Foundation (DFG MA 3913/2) to J.M. and M.S., and a Natural Sciences and Engineering Research Council of Canada Discovery Grant to M.J.H. Dirk Munsterman and an anonymous reviewer improved the manuscript with their constructive comments.

\section{Appendix A. Supplementary data}

Supplementary data to this article can be found online at http:// dx.doi.org/10.1016/j.revpalbo.2012.08.006.

\section{References}

Abels, H.A., Hilgen, F.J., Krijgsman, W., Kruk, R.W., Raffi, I., Turco, E., Zachariasse, W.J., 2005. Long-period orbital control on middle Miocene global cooling: integrated stratigraphy and astronomical tuning of the Blue Clay Formation on Malta. Paleoceanography 20, PA4012.

Alberti, G., 1961. Zur Kenntnis mesozoischer and alttertiärer Dinoflagellaten und Hystrichosphaerideen von Nord- und Mitteldeutschland sowie einigen anderen europäischen Gebieten. Palaeontographica Abteilung A 116, 1-58.

Amigo, A.E., 1999. Miocene silicoflagellate stratigraphy: Iceland and Rockall Plateaus. In: Raymo, M.E., Jansen, E., Blum, P., Herbert, T.D. (Eds.), Proceedings of the Ocean Drilling Program, Scientific Results 162, 63-81 College Station, TX.

Anstey, C.E., 1992. Biostratigraphic and paleoenvironmental interpretation of upper middle Miocene through lower Pleistocene dinoflagellate cyst, acritarch, and other algal palynomorph assemblages from Ocean Drilling Program Leg 105, Site 645, Baffin Bay. Unpublished MSc thesis, University of Toronto, $257 \mathrm{pp}$.

Aubry, M.P., 1993. Neogene allostratigraphy and depositional history of the De Soto Canyon area, northern Gulf of Mexico. Micropaleontology 39, 327-366.

Backman, J., 1984. Cenozoic calcareous nannofossil biostratigraphy from the northeastern Atlantic Ocean - Deep Sea Drilling Project Leg 81. In: Roberts, D.G., Schnitker, D., et al. (Eds.), Initial Reports of the Deep Sea Drilling Project 81. U.S. Government Printing Office, Washington, D.C., pp. 403-428.

Backman, J., Westberg-Smith, M.J., Brown, S., Bukry, D., Edwards, L.E., Harland, R., Huddlestun, P., 1984. Biostratigraphy of Leg 81 sediments-a high latitude record. In: Roberts, D.G., Schnitker, D., et al. (Eds.), Initial Reports of the Deep Sea Drilling Project, 81. U.S. Government Printing Office, Washington, D.C., pp. 855-860.

Benedek, P.N., Sarjeant, W.A.S., 1981. Dinoflagellate cysts from the middle and upper Oligocene of Tönisberg (Niederrheingebiet): a morphological and taxonomical restudy. Nova Hedwigia 35, 313-356.

Bleil, U., 1989. Magnetostratigraphy of Neogene and Quaternary sediment series from the Norwegian Sea: Ocean Drilling Program, Leg 104. In: Eldholm, O., Thiede, J., Taylor, E., et al. (Eds.), Proceedings of the Ocean Drilling Program, Scientific Results 104, 829-901 College Station, TX.

Brown, S., Downie, C., 1985. Dinoflagellate cyst stratigraphy of Paleocene to Miocene sediments from the Goban Spur (Sites 548-550, Leg 80). In: Graciansky, P.C., Poag, C.W., et al. (Eds.), Initial Reports of the Deep Sea Drilling Project, 80. U.S. Government Printing Office, Washington, D.C., pp. 643-651.

Bruns, P., Dullo, W.-C., Hay, W.W., Frank, M., Kubik, P., 1998. Hiatuses on Vøring Plateau: sedimentary gaps or preservation artifacts? Marine Geology 145, 61-84

Bujak, J.P., Davis, D.H., 1981. Neogene dinoflagellate cysts from the Hunt Dome KOPANOAR M-13 Well, Beaufort Sea, Canada. Bulletin of Canadian Petroleum Geology 29, 420-425.

Bujak, J.P., Matsuoka, K., 1986. Late Cenozoic dinoflagellate cyst zonation in the western and northern Pacific. In: Wrenn, J.H., Duffield, S.L., Stein, J.A. (Eds.), Papers from the First Symposium on Neogene Dinoflagellate Cyst Biostratigraphy. AASP Contributions Series, 17. American Association of Stratigraphic Palynologists Foundation, Dallas, Texas, pp. 7-25.

Canninga, G., Zijderveld, J.D.A., van Hinte, J., 1987. Late Cenozoic magnetostratigraphy of Deep Sea Drilling Project Hole 603C, Leg 93, on the North American continental rise off Cape Hatteras. In: van Hinte, J., Wise, S.W.J., et al. (Eds.), Initial Reports of the Deep Sea Drilling Project, 93. U.S. Government Printing Office, Washington, D.C., pp. 839-848.

Channell, J.E.T., Amigo, A.E., Fronval, T., Rack, F., Lehman, B., 1999a. Magnetic stratigraphy at Sites 907 and 985 in the Norwegian-Greenland Sea and a revision of the Site 907 composite section. In: Raymo, M.E., Jansen, E., Blum, P., Herbert, T.D. (Eds.), Proceedings of the Ocean Drilling Program, Scientific Results 162, 131-148 College Station, TX.

Channell, J.E.T., Smelror, M., Jansen, E., Higgins, S.M., Lehman, B., Eidvin, T., Solheim, A., 1999b. Age models for glacial fan deposits off East Greenland and Svalbard (Sites 986 and 987). In: Raymo, M.E., Jansen, E., Blum, P., Herbert, T.D. (Eds.), Proceedings of the Ocean Drilling Program, Scientific Results 162, 149-166 College Station, TX. 
Clement, B., Robinson, F., 1987. Magnetostratigraphy of Leg 94 sediments. In: Ruddiman, W.F., Kidd, R.B., Thomas, E., et al. (Eds.), Initial Reports of the Deep Sea Drilling Project, 94. U.S. Government Printing Office, Washington, D.C., pp. 635-650.

Costa, L.I., Downie, C., 1979. Cenozoic dinocyst stratigraphy of Sites 403 to 406 (Rockall Plateau) IPOD, Leg 48. In: Montadert, L., Roberts, D.G., et al. (Eds.), Initial Reports of the Deep Sea Drilling Project, 48. U.S. Government Printing Office, Washington, D.C., pp. 513-529.

Davis, L.L., McIntosh, W.C., 1996. The petrology and ${ }^{40} \mathrm{Ar} /{ }^{39} \mathrm{Ar}$ age of tholeiitic basalt recovered from Hole 907A, Iceland Plateau. In: Thiede, J., Myhre, A.M., Firth, J.V., Johnson, G.L., Ruddiman, W.F. (Eds.), Proceedings of the Ocean Drilling Program, Scientific Results 151, 351-365 College Station, TX

de Kaenel, E., Villa, G., 1996. Oligocene-Miocene calcareous nannofossil biostratigraphy and paleoecology from the Iberia Abyssal Plain. In: Whitmarsh, R.B., Sawyer, D.S., Klaus, A., Masson, D.G. (Eds.), Proceedings of the Ocean Drilling Program, Scientific Results 149, 79-145 College Station, TX.

De Schepper, S., Head, M.J., 2008. Age calibration of dinoflagellate cyst and acritarch events in the Pliocene-Pleistocene of the eastern North Atlantic (DSDP Hole 610A). Stratigraphy 5, 137-161.

De Schepper, S., Head, M.J., Louwye, S., 2008. Pliocene dinoflagellate cyst stratigraphy, palaeoecology and sequence stratigraphy of the Tunnel-Canal Dock, Belgium. Geological Magazine 146, 92-112.

De Schepper, S., Fischer, E., Groeneveld, J., Head, M.J., Matthiessen, J., 2011. Deciphering the palaeoecology of Late Pliocene and Early Pleistocene dinoflagellate cysts. Palaeogeography, Palaeoclimatology, Palaeoecology 309, 17-32.

de Vernal, A., Mudie, P.J., 1989. Pliocene and Pleistocene palynostratigraphy at ODP Sites 646 and 647, eastern and southern Labrador Sea. In: Srivastava, S.P., Arthur, M., Clement, B., et al. (Eds.), Proceedings of the Ocean Drilling Program, Scientific Results 105, 401-422 College Station, TX

de Verteuil, L., 1996. Data report: Upper Cenozoic dinoflagellate cysts from the continental slope and rise off New Jersey. In: Mountain, G.S., Miller, K.G., Blum, P., Poag, C.W., Twichell, D.C. (Eds.), Proceedings of the Ocean Drilling Program, Scientific Results 150, 439-454 College Station, TX.

de Verteuil, L., 1997. Palynological delineation and regional correlation of Lower through Upper Miocene sequences in the Cape May and Atlantic City boreholes, New Jersey coastal plain. In: Miller, K.G., Snyder, S.W. (Eds.), Proceedings of the Ocean Drilling Program, Scientific Results 150X, 129-145 College Station, TX.

de Verteuil, L., Norris, G., 1996. Miocene dinoflagellate stratigraphy and systematics of Maryland and Virginia. Micropaleontology 42, 1-172 (supplement).

Donders, T.H., Weijers, J.W.H., Munsterman, D.K., Kloosterboer-van Hoeve, M.L., Buckles, L.K., Pancost, R.D., Schouten, S., Sinninghe Damsté, J.S., Brinkhuis, H., 2009. Strong climate coupling of terrestrial and marine environments in the Miocene of northwest Europe. Earth and Planetary Science Letters 281, 215-225.

Dybkjær, K., 2004. Dinocyst stratigraphy and palynofacies studies used for refining a sequence stratigraphic model - uppermost Oligocene to lower Miocene, Jylland, Denmark. Review of Palaeobotany and Palynology 131, 201-249.

Dybkjær, K., Piasecki, S., 2010. Neogene dinocyst zonation for the eastern North Sea Basin, Denmark. Review of Palaeobotany and Palynology 161, 1-29.

Eberli, G.P., Swart, P.K., McNeill, D.F., Kenter, J.A.M., Anselmetti, F.S., Melim, L.A., Ginsburg, R.N., 1997. A synopsis of the Bahamas Drilling Project: results from two deep core borings drilled on the Great Bahamas Bank. In: Eberli, G.P., Swart, P.K., Malone, M.J., Sarg, J.F. (Eds.), Proceedings of the Ocean Drilling Program, Initial Reports 166, 23-41 College Station, TX.

Edwards, L.E., 1984. Miocene dinocysts from Deep Sea Drilling Project Leg 81, Rockall Plateau, eastern North Atlantic. In: Roberts, D.G., Schnitker, D., et al. (Eds.), Initial Reports of the Deep Sea Drilling Project, 81. U.S. Government Printing Office, Washington, D.C., pp. 581-594.

Ellegaard, M., Lewis, J., Harding, I., 2002. Cyst-theca relationship, life cycle, and effects of temperature and salinity on the cyst morphology of Gonyaulax baltica sp. nov. (Dinophyceae) from the Baltic Sea area. Journal of Phycology 38, 775-789.

Engel, E.R., 1992. Palynologische Evidenz klimarelevanter Ereignisse in miozänen Sedimenten des Nordatlantiks. Geologisches Jahrbuch A 125, 3-39.

Expedition 302 Scientists, 2006. Sites M0001-M0004. In: Backman, J., Moran, K., McInroy, D.B., Mayer, L.A., and the Expedition 302 Scientists (Eds.), Proceedings of the Integrated Ocean Drilling Program 302, 1-169 College Station, TX.

Fensome, R.A., Williams, G.L., 2004. The Lentin and Williams index of fossil dinoflagellates, 2004 edition. AASP Contributions Series, 42. American Association of Stratigraphic Palynologists Foundation, Dallas, Texas, 909 pp.

Flower, B.P., Kennett, J.P., 1994. The middle Miocene climatic transition: East Antarctic ice sheet development, deep ocean circulation and global carbon cycling. Palaeogeography, Palaeoclimatology, Palaeoecology 108, 537-555.

Frank, M., Backman, J., Jakobsson, M., Moran, K., O'Regan, M., King, J., Haley, B.A., Kubik, P.W., Garbe-Schönberg, D., 2008. Beryllium isotopes in central Arctic Ocean sediments over the past 12.3 million years: stratigraphic and paleoclimatic implications. Paleoceanography 23, PA1S02.

Fronval, T., Jansen, E., 1996. Late Neogene paleoclimates and paleoceanography in the Iceland-Norwegian Sea: evidence from the Iceland and Vøring Plateaus. In: Thiede, J., Myhre, A.M., Firth, J.V., Johnson, G.L., Ruddiman, W.F. (Eds.), Proceedings of the Ocean Drilling Program, Scientific Results 151, 455-468 College Station, TX.

Gartner, S., Shyu, J.-P., 1996. Aspects of calcareous nannofossil biostratigraphy and abundance in the Pliocene and Late Miocene of Site 905. In: Mountain, G.S. Miller, K.G., Blum, P., Poag, C.W., Twichell, D.C. (Eds.), Proceedings of the Ocean Drilling Program, Scientific Results 150, 53-62 College Station, TX.

Goll, R.M., 1989. A synthesis of Norwegian Sea biostratigraphies: ODP Leg 104 on the Vøring Plateau. In: Eldholm, O., Thiede, J., Taylor, E., et al. (Eds.), Proceedings of the Ocean Drilling Program, Scientific Results 104, 777-826 College Station, TX.
Goll, R.M., Bjørklund, K., 1989. A new radiolarian biostratigraphy for the Neogene of the Norwegian Sea: ODP Leg 104. In: Eldholm, O., Thiede, J., Taylor, E., et al. (Eds.), Proceedings of the Ocean Drilling Program, Scientific Results 104, 697-737 College Station, TX.

Hailwood, E.A., 1979. Paleomagnetism of late Mesozoic to Holocene sediments from the Bay of Biscay and Rockall Plateau, drilled on IPOD Leg 48. In: Montadert, L. Roberts, D.G., et al. (Eds.), Initial Reports of the Deep Sea Drilling Project, 48. U.S Government Printing Office, Washington, D.C., pp. 305-339.

Harland, R., 1979. Dinoflagellate biostratigraphy of Neogene and Quaternary sediments at Holes 400/400A in the Bay of Biscay (Deep Sea Drilling Project Leg 48). In: Montadert, L., Roberts, D.G., et al. (Eds.), Initial Reports of the Deep Sea Drilling Project, 48. U.S. Government Printing Office, Washington, D.C., pp. 531-545.

Head, M.J., 1993. Dinoflagellates, sporomorphs, and other palynomorphs from the Upper Pliocene St. Erth Beds of Cornwall, southwestern England. Journal of Paleontology 67, 1-61.

Head, M.J., 1994. Morphology and paleoenvironmental significance of the Cenozoic dinoflagellate genera Tectatodinium and Habibacysta. Micropaleontology 40, 289-321.

Head, M.J., 1996. Late Cenozoic dinoflagellates from the Royal Society borehole at Ludham, Norfolk, eastern England. Journal of Paleontology 70, 543-570.

Head, M.J., 1997. Thermophilic dinoflagellate assemblages from the mid Pliocene of eastern England. Journal of Paleontology 71, 165-193.

Head, M.J., 1998a. Marine environmental change in the Pliocene and early Pleistocene of eastern England: the dinoflagellate evidence reviewed. Mededelingen Nederlands Institut voor Toegepaste Geowetenschappen TNO 60, 199-226.

Head, M.J., 1998b. Pollen and dinoflagellates from the Red Crag at Walton-on-the-Naze, Essex: evidence for a mild climatic phase during the early late Pliocene of eastern England. Geological Magazine 135, 803-817.

Head, M.J., 1999. The Late Pliocene St. Erth Beds of Cornwall: a review of the palynology and reappraisal of the dinoflagellates. In: Scource, J., Furze, M.F.A. (Eds.), The Quaternary of West Cornwall. Field Guide. Quaternary Research Association, Durham, U.K., pp. 88-92.

Head, M.J., Norris, G., 2003. New species of dinoflagellate cysts and other palynomorphs from the latest Miocene and Pliocene of DSDP Hole 603, western North Atlantic. Journal of Paleontology 77, 1-15.

Head, M.J., Westphal, H., 1999. Palynology and paleoenvironments of a Pliocene carbonate platform: the Clino core, Bahamas. Journal of Paleontology 73, 1-25.

Head, M.J., Wrenn, J.H., 1992. A forum on Neogene and Quaternary dinoflagellate cysts: the edited transcript of a round table discussion held at the Second Workshop on Neogene Dinoflagellates. In: Head, M.J., Wrenn, J.H. (Eds.), Neogene and Quaternary Dinoflagellate Cysts and Acritarchs. American Association of Stratigraphic Palynologists Foundation, Dallas, Texas, pp. 1-31.

Head, M.J., Norris, G., Mudie, P., 1989a. New species of dinocysts and a new species of acritarch from the upper Miocene and lowermost Pliocene, ODP Leg 105, Site 646, Labrador Sea. In: Srivastava, S.P., Arthur, M., Clement, B., et al. (Eds.), Proceedings of the Ocean Drilling Program, Scientific Results 105, 453-466 College Station, TX.

Head, M.J., Norris, G., Mudie, P., 1989b. Palynology and dinocyst stratigraphy of the Miocene in ODP Leg 105, Hole 645E, Baffin Bay. In: Srivastava, S.P., Arthur, M. Clement, B., et al. (Eds.), Proceedings of the Ocean Drilling Program, Scientific Results 105, 467-514 College Station, TX.

Head, M.J., Norris, G., Mudie, P., 1989c. Palynology and dinocyst stratigraphy of the upper Miocene and lowermost Pliocene, ODP Leg 105, Site 646, Labrador Sea. In Srivastava, S.P., Arthur, M., Clement, B., et al. (Eds.), Proceedings of the Ocean Drilling Program, Scientific Results 105, 423-451 College Station, TX.

Head, M.J., Riding, J.B., Eidvin, T., Chadwick, R.A., 2004. Palynological and foraminiferal biostratigraphy of (Upper Pliocene) Nordland Group mudstones at Sleipner, northern North Sea. Marine and Petroleum Geology 21, 277-297.

Jiménez-Moreno, G., Head, M.J., Harzhauser, M., 2006. Early and Middle Miocene dinoflagellate cyst stratigraphy of the Central Paratethys, Central Europe. Journal of Micropalaeontology 25, 113-119.

Knüttel, S., Russel, M.D., Firth, J.V., 1989. Neogene calcareous nannofossils from ODP Leg 105: Implications for Pleistocene paleoceanographic trends. In: Srivastava, S.P., Arthur, M., Clement, B., et al. (Eds.), Proceedings of the Ocean Drilling Program, Scientific Results 105, 245-262 College Station, TX.

Koc, N., Scherer, R.P., 1996. Neogene diatom biostratigraphy of the Iceland Sea Site 907. In: Thiede, J., Myhre, A.M., Firth, J.V., Johnson, G.L., Ruddiman, W.F. (Eds.), Proceedings of the Ocean Drilling Program, Scientific Results 151, 61-74 College Station, TX.

Köthe, A., 2003. Dinozysten-Zonierung im Tertiär Norddeutschlands. Revue de Paléobiologie 22, 895-923.

Köthe, A., 2005. Biostratigraphie an der Oligozän/Miozän-Grenze und im Unter-Miozän der Forschungsbohrung Wursterheide (Kalknannoplankton, Dinozysten, Norddeutschland). Senckenbergiana lethaea 85, 201-229.

Köthe, A., Andruleit, H., 2007. Late Miocene dinoflagellate cysts and calcareous nannoplankton from the eastern North Sea Basin margin: biostratigraphy and palaeoenvironmental interpretation (Breklum research borehole, Germany). Journal of Nannoplankton Research 29, 5-18.

Köthe, A., Piesker, B., 2007. Stratigraphic distribution of Paleogene and Miocene dinocysts in Germany. Revue de Paléobiologie 26, 1-39.

Kuhlmann, G., Langereis, C., Munsterman, D., Van Leeuwen, R.J., Verreussel, R., Meulenkamp, J., Wong, T., 2006a. Chronostratigraphy of Late Neogene sediments in the southern North Sea Basin and paleoenvironmental interpretations. Palaeogeography, Palaeoclimatology, Palaeoecology 239, 426-455.

Kuhlmann, G., Langereis, C.G., Munsterman, D.K., Van Leeuwen, R.J., Verreussel, R. Meulenkamp, J.E., Wong, T.E., 2006b. Integrated chronostratigraphy of the PliocenePleistocene interval and its relation to the regional stratigraphic stages in the southern North Sea region. Geologie en Mijnbouw 85, 19-35. 
Lawrence, K.T., Herbert, T.D., Brown, C.M., Raymo, M.E., Haywood, A.M., 2009. Highamplitude variations in North Atlantic sea surface temperature during the early Pliocene warm period. Paleoceanography 24, PA2218.

Lourens, L., Hilgen, F., Shackleton, N.J., Laskar, J., Wilson, J., 2005. The Neogene. In: Gradstein, F.M., Ogg, J.G., Smith, A.G. (Eds.), A Geologic Time Scale 2004. Cambridge University Press, Cambridge, U.K., pp. 409-430 (Imprinted 2004).

Louwye, S., 2002. Dinoflagellate cyst biostratigraphy of the Upper Miocene Deurne Sands (Diest Formation) of northern Belgium, southern North Sea Basin. Geological Journal 37, 55-67.

Louwye, S., 2005. The Early and Middle Miocene transgression at the southern border of the North Sea Basin (northern Belgium). Geological Journal 40, 441-456.

Louwye, S., De Coninck, J., Verniers, J., 1999. Dinoflagellate cyst stratigraphy and depositional history of Miocene and Lower Pliocene formations in northern Belgium (southern North Sea Basin). Geologie en Mijnbouw 78, 31-46.

Louwye, S., De Coninck, J., Verniers, J., 2000. Shallow marine Lower and Middle Miocene deposits at the southern margin of the North Sea Basin (northern Belgium): dinoflagellate cyst biostratigraphy and depositional history. Geological Magazine $137,381-394$

Louwye, S., Head, M.J., De Schepper, S., 2004. Dinoflagellate cyst stratigraphy and palaeoecology of the Pliocene in northern Belgium, southern North Sea Basin. Geological Magazine 141, 353-378.

Louwye, S., De Schepper, S., Laga, P., Vandenberghe, N., 2007a. The Upper Miocene of the southern North Sea Basin (northern Belgium): a palaeoenvironmental and stratigraphical reconstruction using dinoflagellate cysts. Geological Magazine $144,33-52$

Louwye, S., Foubert, A., Mertens, K., Van Rooij, D., the IODP Expedition 307 Scientific Party, 2007b. Integrated stratigraphy and palaeoecology of the Lower and Middle Miocene of the Porcupine Basin. Geological Magazine 145, 1-24.

Manum, S.B., 1997. Decahedrella martinheadii gen. et sp. nov. - a problematic palynomorph from the Northern Atlantic Miocene. Palynology 21, 67-77.

Manum, S.B., Boulter, M.C., Gunnarsdottir, H., Rangnes, K., Scholze, A., 1989. Eocene to Miocene palynology of the Norwegian Sea (ODP Leg 104). In: Eldholm, O., Thiede, J., Taylor, E., et al. (Eds.), Proceedings of the Ocean Drilling Program, Scientific Results 104, 611-662 College Station, TX

Matsuoka, K., Head, M.J., 1992. Taxonomic revision of the Neogene marine palynomorphs Cyclopsiella granosa (Matsuoka) and Batiacasphaera minuta (Matsuoka), and a new species of Pyxidinopsis Habib (Dinophyceae) from the Miocene of the Labrador Sea. In: Head, M.J., Wrenn, J.H. (Eds.), Neogene and Quaternary Dinoflagellate Cysts and Acritarchs. American Association of Stratigraphic Palynologists Foundation, Dallas, Texas, pp. 165-180.

Matsuoka, K., Bujak, J.P., Shimazaki, T., 1987. Late Cenozoic dinoflagellate cyst biostratigraphy from the west coast of northern Japan. Micropaleontology 33, 214-229.

Matthiessen, J., Knies, J., Vogt, C., Stein, R., 2009a. Pliocene palaeoceanography of the Arctic Ocean and subarctic seas. Philosophical Transactions of the Royal Society A $367,21-48$

Matthiessen, J., Brinkhuis, H., Poulsen, N.E., Smelror, M., 2009b. Decahedrella martinheadii Manum 1997 - a stratigraphically and paleoenvironmentally usefu Miocene acritarch of the northern high latitudes. Micropaleontology 55, 171-186.

McCarthy, F.M.G., Mudie, P.J., 1996. Palynology and dinoflagellate biostratigraphy of Upper Cenozoic sediments from Sites 898 and 900, Iberia Abyssal Plain. In: Whitmarsh, R.B., Samyer, D.S., Klaus, A., Masson, D.G. (Eds.), Proceedings of the Ocean Drilling Program, Scientific Results 149, 241-265 College Station, TX.

McMinn, A., 1992. Neogene dinoflagellate distribution in the eastern Indian Ocean from Leg 123, Site 765. In: Gradstein, F.M., Ludden, J.N., et al. (Eds.), Proceedings of the Ocean Drilling Program, Scientific Results 123, 429-441 College Station, TX.

McMinn, A., 1993. Neogene dinoflagellate cyst biostratigraphy from Sites 815 and 823 Leg 133, northeastern Australian Margin. In: McKenzie, J.A., Davies, P.J., PalmerJulson, A., et al. (Eds.), Proceedings of the Ocean Drilling Program, Scientific Results 133, 97-105 College Station, TX

Mudie, P.J., 1987. Palynology and dinoflagellate biostratigraphy of Deep Sea Drilling Project Leg 94, Sites 607 and 611, North Atlantic Ocean. In: Ruddiman, W.F. Kidd, R.B., Thomas, E., et al. (Eds.), Initial Reports of the Deep Sea Drilling Project, 94. U.S. Government Printing Office, Washington, D.C., pp. 785-812.

Mudie, PJ. 1989. Palynology and dinocyst biostratigraphy of the Late Miocene to Pleistocene, Norwegian Sea: ODP Leg 104, Sites 642 to 644. In: Eldholm, O., Thiede, J. Taylor, E., et al. (Eds.), Proceedings of the Ocean Drilling Program, Scientific Result 104, 587-610 College Station, TX

Müller, C., 1979. Calcareous nannofossils from the North Atlantic (Leg 48). In: Montadert, L., Roberts, D.G., et al. (Eds.), Initial Reports of the Deep Sea Drilling Project, 48. U.S. Government Printing Office, Washington, D.C., pp. 589-639.

Müller, C., 1985. Biostratigraphic and paleoenvironmental interpretation of the Goban Spur region based on a study of calcareous nannoplankton. In: Graciansky, P.C. Poag, C.W., et al. (Eds.), Initial Reports of the Deep Sea Drilling Project, 80. U.S. Government Printing Office, Washington, D.C., pp. 573-599.

Munsterman, D.K., Brinkhuis, H., 2004. A southern North Sea Miocene dinoflagellate cyst zonation. Geologie en Mijnbouw 83, 267-285.

Naafs, B.D.A., Stein, R., Hefter, J., Khèlifi, N., De Schepper, S., Haug, G.H., 2010. Late Pliocene changes in the North Atlantic Current. Earth and Planetary Science Letters $298,434-442$.

Piasecki, S., 1980. Dinoflagellate cyst stratigraphy of the Miocene Hodde and Gram Formations, Denmark. Bulletin of the Geological Society of Denmark 29,53-76.

Piasecki, S., 2003. Neogene dinoflagellate cysts from Davis Strait, offshore West Greenland. Marine and Petroleum Geology 20, 1075-1088.

Piasecki, S., 2005. Dinoflagellate cysts of the Middle-Upper Miocene Gram Formation, Denmark In: Roth, F. Hoedemarkers, K (Eds.), The Gram Book Palaeontos, vol. 7. Midtsønderjyllands Museum, Gram Slot, pp. 29-45.
Piasecki, S., Gregersen, U., Johannessen, P.N., 2002. Lower Pliocene dinoflagellate cysts from cored Utsira Formation in the Viking Graben, northern North Sea. Marine and Petroleum Geology 19, 55-67.

Poirier, A., Hillaire-Marcel, C., 2011. Improved Os-isotope stratigraphy of the Arctic Ocean. Geophysical Research Letters 38, L14607.

Poore, R.Z., 1979. Oligocene through Quaternary planktonic foraminiferal biostratigraphy of the North Atlantic: DSDP Leg 49. In: Luyendyk, B.P., Cann, J.R., Sharman, G.S., et al. (Eds.), Initial Reports of the Deep Sea Drilling Project, 49. U.S. Government Printing Office, Washington, D.C., pp. 447-517.

Poulsen, N.E., Manum, S.B., Williams, G.L., Ellegaard, M., 1996. Tertiary dinoflagellate biostratigraphy of Sites 907, 908, and 909 in the Norwegian-Greenland Sea. In: Thiede, J., Myhre, A.M., Firth, J.V., Johnson, G.L., Ruddiman, W.F. (Eds.), Proceedings of the Ocean Drilling Program, Scientific Results 151, 255-287 College Station, TX.

Rasmussen, E.S., Heilmann-Clausen, C., Waagstein, R., Eidvin, T., 2008. The Tertiary of Norden. Episodes 31, 66-72.

Rögl, F., 1999. Mediterranean and Paratethys. Facts and hypotheses of an Oligocene to Miocene paleogeography (short overview). Geologica Carpathica 50, 339349.

Ruddiman, W.F., Glover, L.K., 1972. Vertical mixing of ice-rafted volcanic ash in North Atlantic sediments. Geological Society of America Bulletin 83, 2817-2836.

Santarelli, A., Brinkhuis, H., Hilgen, F.J., Lourens, L.J., Versteegh, G.J.M., Visscher, H., 1998. Orbital signatures in a Late Miocene dinoflagellate record from Crete (Greece). Marine Micropaleontology 33, 273-297.

Shipboard Scientific Party, 1995. Site 907. In: Myhre, A.M., Thiede, J., Firth, J.V., et al. (Eds.), Proceedings of the Ocean Drilling Program, Initial Reports 151, 57-111 College Station, TX.

Smelror, M., 1999. Pliocene-Pleistocene and redeposited dinoflagellate cysts from the western Svalbard Margin (Site 986): biostratigraphy, paleoenvironment, and sediment provenance. In: Raymo, M.E., Jansen, E., Blum, P., Herbert, T.D. (Eds.), Proceedings of the Ocean Drilling Program, Scientific Results 162, 83-97 College Station, TX.

Snyder, S.W., Müller, C., Townsend, H., Poag, C.W., 1985. Biostratigraphy, paleoenvironmental, and paleomagnetic synthesis of the Goban Spur region, Deep Sea Drilling Project Leg 80. In: Graciansky, P.C., Poag, C.W., et al. (Eds.), Initial Reports of the Deep Sea Drilling Project, 80. U.S. Government Printing Office, Washington, D.C., pp. 1169-1186.

Soliman, A., Head, M.J., Louwye, S., 2009. Morphology and distribution of the Miocene dinoflagellate cyst Operculodinium? borgerholtense Louwye 2001, emend. Palynology 33 (2), 73-85.

Soliman, A., Corić, S., Head, M.J., Piller, W., El Beialy, S.Y., 2012. Lower and Middle Miocene biostratigraphy, Gulf of Suez, Egypt based on dinoflagellate cysts and calcareous nannofossils. Palynology 36, 1-42.

Spiegler, D., Jansen, E., 1989. Planktonic foraminifer biostratigraphy of Norwegian Sea sediments: ODP Leg 104. In: Eldholm, O., Thiede, J., Taylor, E., et al. (Eds.), Proceedings of the Ocean Drilling Program, Scientific Results 104, 681-696 College Station, TX.

Stockmarr, J., 1977. Tablets with spores used in absolute pollen analysis. Pollen et Spores 13, 615-621.

Stover, L.E., 1977. Oligocene and Early Miocene dinoflagellates from Atlantic corehole 5/5B, Blake Plateau. AASP Contributions Series, 5A. American Association of Stratigraphic Palynologists Foundation, Dallas, Texas, pp. 66-89.

Stover, L.E., Brinkhuis, H., Damassa, S.P., de Verteuil, L., Helby, R.J., Monteil, E., Partridge, A.D., Powell, JA, Riding JB., Smelror, M., Williams, G.L, 1996. Mesozoic-Tertiary dinoflagellates, acritarchs and prasinophytes. In: Jansonius, J., McGregor, D.C. (Eds.), Palynology: Principles and Applications, vol. 2. American Association of Stratigraphic Palynologists Foundation, Dallas, Texas, pp. 641-750.

Strauss, C., Lund, J.J., 1992. A Middle Miocene dinoflagellate cyst microflora from Papendorf near Hamburg, Germany. Mitteilung Geologisch-Paläontologisches Institut Universität Hamburg 73, 159-189.

Strauss, C., Lund, J.J., Lund-Christensen, J., 2001. Miocene dinoflagellate cyst biostratigraphy of the Nieder Ochtenhausen research borehole (NW Germany). Geologisches Jahrbuch A 152, 395-447.

Talwani, M., Eldholm, O., 1977. Evolution of the Norwegian-Greenland Sea. Geological Society of America Bulletin 88, 969-999.

Udeze, C.U., Oboh-Ikuenobe, F.E., 2005. Neogene palaeoceanographic and palaeoclimatic events inferred from palynological data: Cape Basin off South Africa, ODP Leg 175. Palaeogeography, Palaeoclimatology, Palaeoecology 219, 199-223.

Verhoeven, K., Louwye, S., Eiriksson, J., De Schepper, S., 2011. A new age model for the Pliocene-Pleistocene Tjörnes section on Iceland: its implication for the timing of North Atlantic-Pacific palaeoceanographic pathways. Palaeogeography, Palaeoclimatology, Palaeoecology 309, 33-52.

Versteegh, G.J.M., 1997. The onset of major Northern Hemisphere glaciations and their impact on dinoflagellate cysts and acritarchs from the Singa section, Calabria (southern Italy) and DSDP Holes 607/607A (North Atlantic). Marine Micropaleontology 30, 319-343.

Vogt, P.R., Johnson, G.L., Kristjansson, L., 1980. Morphology and magnetic anomalies north of Iceland. Journal of Geophysics 47, 67-80.

Warny, S.A., Wrenn, J.H., 2002. Upper Neogene dinoflagellate cyst ecostratigraphy of the Atlantic coast of Morocco. Micropaleontology 48, 257-272.

Weaver, P.E., Clement, B., 1987. Magnetobiostratigraphy of planktonic foraminiferal datums: Deep Sea Drilling Project Leg 94, North Atlantic. In: Ruddiman, W.F. Kidd, R.B., Thomas, E., et al. (Eds.), Initial Reports of the Deep Sea Drilling Project, 94. U.S. Government Printing Office, Washington, D.C., pp. 815-829.

Williams, G.L., 1975. Dinoflagellate and spore stratigraphy of the Mesozoic-Cenozoic offshore Canada. Geological Survey of Canada Paper 30, 107-163. 
Williams, G.L., Bujak, J.P., 1985. Mesozoic and Cenozoic dinoflagellates. In: Bolli, H.M. Saunders, J.B., Perch-Nielsen, K. (Eds.), Plankton Stratigraphy. Cambridge University Press, Cambridge, U.K., pp. 847-964.

Williams, G.L., Manum, S.B., 1999. Oligocene-Early Miocene dinocyst stratigraphy of Hole 985A (Norwegian Sea). In: Raymo, M.E., Jansen, E., Blum, P., Herbert, T.D. (Eds.), Proceedings of the Ocean Drilling Program, Scientific Results 162, 99-109 College Station, TX.

Williams, G.L., Brinkhuis, H., Bujak, J.P., Damassa, S.P., Hochuli, P.A., de Verteuil, L. Zevenboom, D., 1998. Appendix. In: de Graciansky, P.C., Hardenbol, J., Jacquin, T. Vail, P.R. (Eds.), Mesozoic and Cenozoic Sequence Stratigraphy of European Basins. SEPM Special Publication, 60. SEPM (Society for Sedimentary Geology), Tulsa, Oklahoma.

Williams, G.L., Brinkhuis, H., Pearce, M.A., Fensome, R.A., Weegink, J.W., 2004. Southern Ocean and global dinoflagellate cyst events compared: index events for the Late
Cretaceous-Neogene. In: Exon, N.F., Kennett, J.P., Malone, M.J. (Eds.), Proceedings of the Ocean Drilling Program, Scientific Results 189, 1-98 College Station, TX.

Wolf-Welling, T.C.W., Cremer, M., O'Connell, S., Winkler, A., Thiede, J., 1996. Cenozoic Arctic gateway paleoclimate variability: indications from changes in coarse-fraction compostion. In: Thiede, J., Myhre, A.M., Firth, J.V., Johnson, G.L. (Eds.), Proceedings of the Ocean Drilling Program, Scientific Results 151, 515-567 College Station, TX.

Wrenn, J.H., Kokinos, J.P., 1986. Preliminary comments on Miocene through Pleistocene dinoflagellate cysts from De Soto Canyon, Gulf of Mexico. In: Wrenn, J.H., Duffield, S.L., Stein, J.A. (Eds.), Papers from the First Symposium on Neogene Dinoflagellate Cyst Biostratigraphy. AASP Contributions Series, 17. American Association of Stratigraphic Palynologists Foundation, Dallas, Texas, pp. 169-225.

Zevenboom, D., 1995. Dinoflagellate cysts from the Mediterranean Late Oligocene and Miocene. CIP-Gegevens Koninklijke Bibliotheek, Den Haag, 221 pp. (Published Ph.D. thesis, Biology Faculty, State University of Utrecht, Netherlands). 